\title{
Perfect Periphrases in Post-Classical and Early Byzantine Greek: An Ecological-Evolutionary Account ${ }^{*}$
}

\author{
Klaas Bentein \\ Ghent University, Belgium \\ klaas.bentein@ugent.be
}

\begin{abstract}
I analyze the use and development of perfect periphrases with the verbs "be" ( $\varepsilon i \mu i)$ and "have" $\left(\varepsilon^{\prime} \chi \omega\right)$ in Post-classical and Early Byzantine Greek. While their importance has often been stressed in the context of the restructuring of the verbal system (more in particular the loss of the synthetic perfect), they have not received an in-depth, corpus-based treatment yet. The approach adopted in this article builds on insights from recently developed ecological-evolutionary models, which recognize the fact that language change is a two-step process, consisting of innovation and propagation, and that multiple 'ecologogical' factors influence the spread of a construction through the population (what I discuss in terms of 'register').
\end{abstract}

Keywords

Ancient Greek; perfect; periphrasis; diachrony; ecology; register

\section{Introduction}

This article discusses the development of the Post-classical and Early Byzantine Greek verbal system, concentrating on the functional domain of perfect aspect. ${ }^{1}$

\footnotetext{
*) Parts of this article were presented at the Fifth International Conference of the German Cognitive Linguistics Association (Freiburg, October 10-12, 2012). I would like to thank Wolfgang de Melo, Trevor Evans, Mark Janse, Albert Rijksbaron and an anonymous referee of Journal of Greek Linguistics for their helpful comments on previous versions of the article (any mistakes or inaccuracies remain entirely my own responsibility). My work was funded by the Special Research Fund of Ghent University (grant no. o1D23409).

1) The aspectual functions of the perfect (as a universal semantic category) can be placed onto a continuum which ranges from subject/state-orientedness to event-orientedness, with a major distinction between a stative/resultative perfect (e.g. ö $\lambda \omega \lambda \alpha$ (olöla) "I am destroyed", $\lambda \dot{\varepsilon} \lambda \nu \tau \alpha \mathrm{l}$ (lelutai) "it is solved"), denoting the state in which the subject finds him/her/itself (whether or not as a

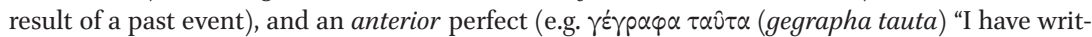

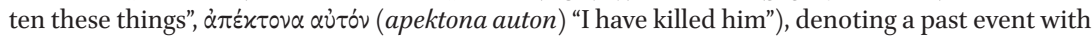
current relevance.
} 
As shown by Haspelmath (1992) among others, during its history the so-called 'synthetic' perfect underwent two major semantic shifts ${ }^{2}$ (both shifts being common from a cross-linguistic point of view, see Bybee \& Dahl 1989; Bybee, Perkins \& Pagliuca 1994), whereby it came to denote an increasingly more salient (past) event. Appearing in Archaic/Homeric Greek with a stative/resultative function (as in $\pi \dot{\varepsilon} \pi \eta \gamma \alpha$ (pepēga) "I am stuck"), it developed into an anterior perfect in Classical Greek (though maintaining its earlier resultative function), a semantic shift which increased its past-orientedness (now denoting the current relevant of a past event, as in $\tau \alpha \hat{v} \tau \alpha \dot{\alpha} x \eta x o ́ \alpha \tau \varepsilon$ (tauta akēkoate) "you have heard this"). This tendency continued in Post-classical Greek, where the synthetic perfect even came to be used as a perfective past. ${ }^{3}$ This second semantic shift brought the synthetic perfect in direct competition with the synthetic aorist, eventually leading to its disappearance.

In this context, many scholars have drawn attention to the importance of periphrastic constructions (partially) replacing the synthetic perfect (see, e.g., Gerö \& Von Stechow 2003:283; Dickey 2009:155; Horrocks 2010:178), together with the aorist. ${ }^{4}$ In what is still the standard work on the subject, Aerts (1965)

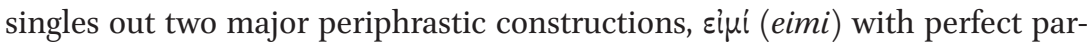

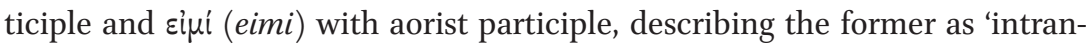
sitive and situation-fixing' (i.e. resultative) and characterizing the latter as a 'pluperfect periphrasis' (i.e. past anterior (presumably)). Aerts (1965:161) also refers to the construction of है $\chi \omega(e k h \bar{o})$ with passive perfect participle, but does not consider it periphrastic. In this article, I present the results of a corpusbased investigation into the diachrony of perfect periphrases with gi $\mu$ i (eimi) and $\varepsilon^{\prime} \chi \omega(e k h \bar{o})$, showing (a) that the standard account is oversimplified when it comes to the use and diachrony of these (two/three) major periphrases, and (b) that the number of different perfect periphrases is much greater than has commonly been assumed (due to the fact that there has not been any systematic investigation of a representative corpus of texts; but see most recently

\footnotetext{
2) There is no consensus as to when these shifts should be dated, which can be (partly) attributed to the fact that we are dealing with a continuous process, whereby examples with the old aspectual function still remain in use. The first shift is often dated to the Classical period (V-IV BC) (but see Ruijgh 2004:32 for an earlier dating), and the second shift to the Early Post-classical period (III-I BC) (but see McKay 1980:23 and Porter 1989:273 for a much later dating).

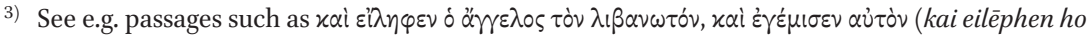
angelos ton libanōton, kai egemisen auton) (Rev. 8.5) "and the angel took the censer and filled it", where the perfect is co-ordinated with an aorist form.

4) Already in the Archaic and Classical periods, the aorist could be used with a perfect-like value. See e.g. Mandilaras (1972:14; 'perfective aorist') and Friedrich (1974:12; 'resultative aorist').
} 
Giannaris 2011a, 2011b, focusing on the construction with si $\mu i$ (eimi)). I concentrate on the period from the third century $\mathrm{BC}$ tot the eighth century $\mathrm{AD}$, which I divide into four sub-periods (based on a suggestion by Lee 2007:113), called 'Early Post-classical Greek' ('EPG'; 3rd-1st c. BC), 'Middle Post-classical Greek' ('MPG'; 1st-3rd c. AD), 'Late Post-classical Greek' ('LPG'; 4th-6th c. AD) and 'Early Byzantine Greek' ('EBG'; 7th-8th c. AD).

The linguistic study of the Post-classical and Byzantine periods confronts us with a number of difficulties. One element which is particularly often referred to concerns the nature of our primary (written) sources. As Browning (1969:13) writes, "any formal utterance, and in particular any written sample of language, differed considerably from 'normal' speech". In general, the approach that has been advocated for the past decades has consisted in attempting to reconstruct or approximate the spoken language, by focusing almost exclusively on 'authentic' texts such as the papyri and other low/middle-register documents (see e.g. Mirambel 1966:169-170; Browning 1969:14; Moser 1988:17; for 'textual authenticity', see Herring, van Reenen \& Schøsler 2000). I should stress from the outset that this is not my intention. In my view, this strategy does injustice not only to the fundamental difference between spoken and written texts (Biber \& Conrad 2009:85, 109), but also to their interrelationship. I take it that Ancient Greek can only be approached as a text-language (Fleischman 2000), and that our primary aim should be to describe and analyze the variation found in different types of texts (cf. similarly Manolessou 2008:74), rather than trying "to acquire a complete picture of the contemporary vernacular" (Markopoulos 2009:17).

Before going into the analysis of perfect periphrases with sipi (eimi) and है $\chi \omega$ $(e k h \bar{o})(\S 4)$, I introduce the theoretical framework adopted in this article $(\S 2)$, and its application to written text $\left(\S_{3}\right)$.

\section{The Ecological-Evolutionary Framework}

In order to describe and analyze the variation found in the texts under analysis, I adopt an 'ecological-evolutionary' perspective. In this framework, language is explicitly compared to other cultural and natural phenomena such as biological life, human and animal societies, national economies, the internet etc., ${ }^{5}$ and their evolutionary principles are compared (though not excluding 'speciesspecific principles', Mufwene 2001:145). While in the nineteenth century attention was repeatedly drawn to similarities between linguistics and biology, in

\footnotetext{
5) For a number of typical characteristics of complex adaptive systems, see e.g. Mufwene (2001:157).
} 
the twentieth century (with the advent of structuralism and its intellectual successor, generative grammar) such parallels were no longer appreciated (to say the least). In recent years, however, evolutionary models of language have again increased in popularity (Croft 2002:75 speaks of a "renaissance of interest"), perhaps due to the influence of socio-historical linguistics. In what follows, I focus on the work of two leading proponents, Croft (e.g. 2000, 2002, 2006a, 2006b) and Mufwene (e.g. 2001, 2008).

\subsection{Language: Multiple Levels of Existence}

Language is considered to exist at two main (interdependent) levels, namely that of the individual (as idiolect) and the community (as communal language, which is conceived of as a population of idiolects) (Mufwene 2001; what Frank \& Gontier 2010 call the 'local' and the 'global' level). Contrary to what is upheld by linguists working within the generative paradigm, ${ }^{6}$ not homogeneity but (structured) heterogeneity is central to the ecological-evolutionary framework, at both of the above-mentioned levels.

As Frank \& Gontier (2010:41-42) note, both levels belong to one single unified dynamic system. They describe the interrelationship between these two levels in terms of a bottom-up and top-down process (Frank \& Gontier 2010:39):

The CAS [Complex Adapative System, KB] approach to language states that global order derives from local interactions. Language agents are carriers of individual linguistic knowledge which becomes overt behavior in local interactions between agents. Through these local level (microscopic) interactions agents construct and acquire individual ontologies, lexicons and grammars. When the latter are sufficiently entrenched within the system, they become part of the global level (macroscopic) properties of collective ontologies, lexicons and grammars of the speech community. Actually, the process is even non-linear in the sense that individual ontologies, lexicons and grammars continuously contribute to and, in turn, are influenced by the global level.

Of course, the dichotomy between individual and global is a very general one, which can be further refined (especially with regard to the global level). Croft (2000:90-94, 166-173) for example recognizes two types of societal heterogeneity. Firstly, a society is made up out of different speech communities, which can be defined in terms of (social) domains (e.g. school, family, friends) or shared expertise (e.g. linguistics, cooking, informatics), rather than individuals. Since each individual typically belongs to multiple speech communities, each

6) Cf. the oft-quoted passage where Chomsky (1965:3-4) writes that "linguistic theory is concerned with an ideal speaker-listener, in a completely homogeneous speech-community, who knows its language perfectly and is unaffected by such grammatically irrelevant conditions as memory limitations, distractions, shifts of attention and interest, and errors (random or characteristic) in applying his knowledge of the language in actual performance". 
with their own $\operatorname{code}^{7}$ (s)he will speak multiple codes (known as the individual's repertoire). Secondly, Croft also recognizes the existence of socialnetworks, which provides an alternative (lower-level) way of looking at speech communities, focusing on the individual. The social network of a given individual consists of the links between that individual and the other persons with whom (s)he is in contact.

\subsection{Language Evolution}

The most detailed model of language evolution that has been proposed so far is that of Croft (called "the theory of utterance selection" or TUS; see especially Croft 2000, 2006a, 2006b). Rather than using metaphors or analogies derived from biological evolution, Croft starts from an abstract model of change, which distinguishes between three types of replication, that is, normal replication, altered replication and differential replication.

Before looking into the details of Croft's proposal, we must clarify what the basic unit of language evolution (called replicator) is and how exactly it is replicated. Croft (2002:79) calls the unit of replication the lingueme ${ }^{8}$ (compare Nettle's 1999 item and Mufwene's 2001 (linguistic) feature), and defines it as 'a token of linguistic structure', "anything from a phoneme to a morpheme to a word to a syntactic construction, and also their conventional semantic/discoursefunctional (information-structural) values". ${ }^{9}$ Linguemes are replicated through utterances (Croft 2002:78, adopting an 'utterance-based model of language change') ${ }^{10}$

In what follows, I discuss the three types of replication. As the reader will notice, Croft's evolutionary model attaches great importance to the notion of convention (see Croft 2006b: 89 "linguistic convention governs all processes of change"), which allows us to account for stasis as well as change.

\footnotetext{
7) Of course, much of the language of such specialized communities overlaps, especially when it comes to core expertise (Croft 2002:81).

8) The notion of lingueme resembles that of construction known from Cognitive Linguistics (especially that branch called 'Construction Grammar'), of which Croft is one of the main proponents. As this notion carries the same load and is much more familiar to most linguists, I use it in the remainder of this article.

9) Croft furthermore distinguishes between schematic and substance linguemes (words and morphemes can be called substance linguemes, as they have actual phonemic substance).

10) Croft's view entails that as we are communicating we are constantly engaging in abstraction and analysis: "abstraction and analysis are the primary grammatical proceses in language use.... We are presented with grammatical wholes and must analyze them into their component units, syntactic and semantic, in the process of learning and (re)using language. ... The result of this process is a mapping from syntactic units onto components of meaning in the speaker's mind" (Croft 2000:118).
} 


\subsubsection{Normal Replication}

This first type of replication can be defined in terms of conformity to convention. Every time we speak, structures (e.g. sounds, words and larger constructions) which we have encountered in previous utterances are copied (replicated).

\subsubsection{Altered Replication ('Innovation')}

Obviously, communication is hardly limited to identical replication: replication is always imperfect to some extent, most importantly because language use (to a large extent) is a creative recombination process, involving the (novel) combination of words and constructions of previously heard (and subsequently internalized) utterances (Croft 2006a: 106), thus producing variation (what Croft 2006a: 98-99 calls 'first-order variation'). As Garner (2005:96) observes, speakers constantly 'misuse' and invent words, and 'break the rules' of morphology and syntax (through 'error' or creativity, or a combination of both). This is called altered replication, or breaking convention. Through altered replication, variation arises, e.g. alternative pronunciations for the same word: [ru:t] $\sim$ rawt] for route; alternative terms for the same denotatum: coke $\sim$ soft drink $\sim$ soda; alternative syntactic constructions: there are $\sim$ there's $\sim$ it's a lot of people there (I borrow these examples from Mufwene 2008:69). The totality of variants for a given variable is called the 'lingueme pool' (compare Nettle's 1999 linguistic pool and Mufwene's 2001 feature pool).

\subsubsection{Differential Replication ('Propagation' and 'Selection')}

Most often, the changes made by individual speakers will not have any effect on the communal language (Croft 2002:52). However, variants may also be differentially replicated: a variant which came into existence into one community will then spread to other communities via an innovator who has network ties with both communities (what Mufwene 2001:18 calls a 'macro-evolutionary development', and Croft 2006a: 98-99 'second-order variation'). Possibly, the other variants will then be eliminated. However, variation does not necessarily lead to elimination: variants can also survive in a newly defined niche, either through functional specialization (elimination of synonymy, division of the meaning/use of the competing forms) or social specialization (the variants are associated with distinct communities) (Croft 2000:177). Propagation can be considered the adoption and establishment of a new convention (in other words, new communal norms emerge). Once an innovation is sufficiently established (normalized/conventionalized/generalized), the social mechanisms that led to the prop- 
agation of the innovation in an earlier stage need no longer be at work (it is then normally replicated).

\subsection{Causal Mechanisms}

As Croft (2002:80) notes, "the generalized theory of selection does not specify the causal mechanisms that cause replication, particularly altered replication, and selection". In other words, these mechanisms are domain- (i.e. language-) specific. Croft distinguishes between three kinds of mechanisms, teleological, intentional and non-intentional ones, the first of which he (largely) dismisses. Croft furthermore makes a strict distinction between mechanisms for normal/ altered replication on the one hand and those for differential replication on the other: the mechanisms for the former are considered functional and those for the latter social. In what follows, I give a brief overview of the main causal mechanisms.

\subsection{1. (Functional) Mechanisms for Normal Replication}

The main (intentional) mechanism for normal replication is conformity to convention (see Keller's 1994:94 maxim “talk in such a way that you are not misunderstood"). Croft also mentions the non-intentional mechanism of 'entrenchment' (i.e. psychological routinization due to frequency of occurrence).

\subsection{2. (Functional) Mechanisms for Altered Replication}

With regard to the intentional mechanisms for altered replication, Croft again refers to Keller's (1994:101) maxims, most importantly the economy principle ("talk in such a way that you do not expend superfluous energy") and the principle of increased expressiveness (Keller 1994:101 provides a series of maxims such as "talk in such a way that you are noticed", "talk in an amusing, funny etc. way"). Crucial for altered replication are also a series of non-intentional mechanisms, most importantly form-function reanalysis (i.e. "the reanalysis of the mapping between morphosyntactic form in constructions and the semantic content that they denote"; Croft 2006b: 82). Additionally, altered replication can come about through interference (the production of a foreign language lingueme through interlingual identification) and its language-internal variant intraference (the creation of a novel variant of a form with a new meaning through intralingual identification). 


\subsection{3. (Social) Mechanisms for Selection}

In Croft's framework, the propagation of a change is socially determined:"11 the main intentional mechanisms for selection are social identification, (covert) prestige, $^{12}$ and accommodation. As Croft (2000:176) notes, "there appears to be a natural human tendency for a community to select one alternative as the conventional signal for a recurrent coordination problem". However, Croft also recognizes a non-intentional mechanism for selection, namely the (sociopsychological) factor of change in entrenchment (what Croft 2002:83 calls 'interactor-environment interaction'): when a given lingueme is socially less desirable, it will be less entrenched, and thus less often used.

\subsection{The Actuation Problem and Language Ecology}

With regard to the threefold distinction made in $\S 2.3$, especially the mechanisms for selection have received much discussion. This issue, known as the 'actuation problem', is formulated as follows by McMahon (1994:248): "the real actuation question is why some of these innovations [by individual speakers, $\mathrm{KB}$ ] die out and others catch on, spreading through the community, or why certain instances of variation become change while others don't".

Various scholars do not maintain the strict distinction Croft makes between innovation and functional motivation on the one hand, and selection and social motivation on the other. Nettle (1999) and Haspelmath (1999), for example, both suggest that functional motivations can account for the selection of an innovation (on a par with environmental adaptation in biology). The recent overview-article published by Hruschka et al. (co-authored by Croft) similarly recognizes that "many factors can plausibly influence the rate and success with which novel form-function mappings spread through populations" (2009:467), among others learnability, ease of use or expressivity of the construction, the structure of language itself, social factors, and population structure.

One approach which explicitly takes into account the interaction of such multiple factors (functional and social), and which I follow here, combines

\footnotetext{
11) This does not mean that every production of an innovation after the first one will be socially motivated (Croft 2006b: 81): a given variant can be produced independently many times before it acquires a social value.

12) The role of prestige as a social factor has not been without discussion. Milroy \& Milroy (1985:369-370) argue that "although a successful innovation needs in some sense to be postively evaluated, generalizations can be made about the social mechanisms controlling innovation and diffusion quite independently of the prestige value attached to any given innovation". Moreover, it has been observed that linguistic innovations can diffuse both upwards and downwards through the social hierarchy (Milroy \& Milroy 1985:381).
} 
the evolutionary framework with a so-called 'ecological' perspective (Mufwene 2001, 2008). Similarly to Croft, Mufwene recognizes the existence of the evolutionary processes of innovation and selection (though Mufwene's focus lies mostly on the latter). However, Mufwene approaches selection (at both levels) by means of the concept of ecology, which is derived from Ancient Greek oixos "house" and is employed in biology to express the idea that the whole earth is like a vast, interrelated household (Garner 2004:23). By extension, ecological thinking in linguistics (first introduced by Einar Haugen in the 1970s) is concerned with the context in which language is used, including both languageinternal and language-external ecological factors:

\subsubsection{Language-Internal Ecology}

One of the main language-internal ecological factors is variation, and the nature and size of the competing variants (in terms of frequency). Mufwene (2001:30) notes the following: "when there are alternative strategies for the same or similar grammatical functions, each of the variants becomes part of the ecology for the others and each one of them can be affected by what happens to the others" (compare Nettle 1999:9 on ecological linkage: "every item evolves in an ecosystem formed by the other items around it in the linguistic pool" and 34: "the total linguistic context acts as an ecosystem for any particular linguistic item"). Language-internal ecology also depends on simple systemic relations among different aspects of the linguistic system (cf. Nettle 1999:55).

\subsubsection{Language-External Ecology}

Language-external factors act on a particular language through its 'hosts', the speakers. One very important ecological factor which is everywhere in our dayto-day interactions is language contact (Mufwene 2001:18) and multilingualism in general (Mufwene 2008:181). Another major ecological factor is called 'social ecology', referring to the impact of the social status of the model speakers of a given variant on its propagation, which imposes a 'ranking' of variants (compare with Croft's social mechanisms for differential replication).

\section{Applying the Ecological-Evolutionary Framework to Written Text}

The ecological-evolutionary approach provides a powerful theoretical framework for the study of linguistic variation. However, one (very important) question remains to be sorted out, namely how the framework can be operationalized for the study of written text. To be more specific, what is needed is a general concept that enables us to compare the variation found in a broad range of 
texts (so not exclusively 'spoken-like' or 'authentic' ones) ${ }^{13}$ and possibly to relate our findings to the spoken language (though for text-languages such as Ancient Greek the latter must remain hypothetical, and does not concern us here). I believe the concept of register is particularly relevant to such purposes. While there have been some studies on register in Ancient (mostly Post-classical) Greek (see e.g. Porter 1989:152-153; O'Donnell 2000; Willi 2003, 2010), most of these have been synchronically oriented. One scholar who has related register to diachrony is Markopoulos (2009). In his study of the diachrony of Ancient Greek future periphrases with the verbs है $\chi \omega(e k h \bar{o})$ "I have", $\theta \dot{\varepsilon} \lambda \omega($ thelō "I want" and $\mu \dot{\varepsilon} \lambda \lambda \omega$ (mellō) "I am about to", Markopoulos observes the following:

The rise in the frequency of use and the establishment of a construction in a specific register almost without exception follows the demise of another in the same register, so that a situation whereby two or more AVCs [= auxiliary verb ('periphrastic') constructions, KB] are equally frequent in a genre or in all contexts in a period never obtains.

(Markopoulos 2009:226)

Markopoulos furthermore posits a so-called 'fifth, sociolinguistic, parameter of grammaticalization', which predicts that "the further grammaticalized an AVC becomes, the higher up it rises in terms of sociolinguistic (register) acceptability" (Markopoulos 2009:232). From an ecological-evolutionary perspective, both observations make perfect sense, in view of what has been called 'differential replication' (i.e. the gradual spread of innovative constructions and the elimination of variants).

A register can be broadly described as "a variety associated with a particular situation of use (including particular communicative purposes)" (Biber \& Conrad 2009:6), presenting a set of typical linguistic features. Biber \& Conrad (2009:2) note that one can also study a text from a genre or a style-perspective, but that these perspectives are more specialized ("a register analysis seeks to characterize a variety of language - not a particular text or an individual writer's style"; Biber \& Conrad 2009:10). Registers can be defined at various levels of specificity (Biber \& Conrad 2009:32-33; Willi 2010:304), depending on the number of situational characteristics one takes into account (for an overview of such characteristics, see Biber \& Conrad 2009:40). Perhaps the most well-known classification of registers in Post-classical Greek is that proposed by Porter (1989:152-153) and O'Donnell (2000:277), who recognize four main groups: 'vulgar' (e.g. papyri concerned with personal matters), 'non-literary' (e.g. official business papyri, Epictetus), 'literary’ (Philo, Josephus, Polybius)

13) For a similar perspective, cf. O’Donnell (2000:277-278): "in compiling a corpus of Hellenistic Greek ... it is also important to represent the broader extremes of the continuum, that is, both vulgar and Atticistic language, so that the whole of the language is represented and comparison studies can be undertaken". 
and 'Atticistic' (Dionysius of Halicarnassus, Plutarch). For the purposes of this article, I make use of a threefold distinction between 'low', 'middle', and 'high' (following the recent studies of Høgel 2002 and Markopoulos 2009). Whether we recognize four or three registers, what is important is that these constitute points on a continuum. Two authors (or even one and the same) can both write in a linguistically high level, but differ in degree of Atticism. ${ }^{14}$

When compiling a corpus, it is thus important to make it 'register-balanced' (O'Donnell 2000), so as to be able to describe variation in texts from different linguistic levels, and to analyze their interrelationship. I have compiled a corpus consisting of texts belonging to three groups, (1) non-literary (documentary) papyri, (2) biographical/hagiographical texts, and (3) historiographical texts, covering the period from the third century $\mathrm{BC}$ to the eighth century AD. ${ }^{15}$ Generalizing, the non-literary papyri can be located towards the left side of the register-continuum, the biographical/hagiographical texts towards the middle, and the historiographical ones towards the right side, as shown in figure 1 :

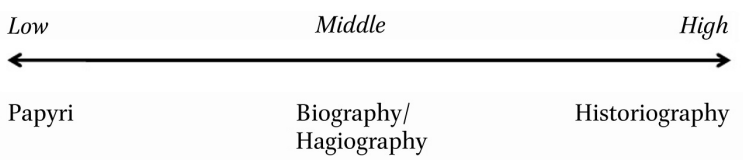

Figure 1. The register-continuum (Post-classical and Early Byzantine Greek).

In what follows, I discuss each of these groups in greater detail, with particular attention to three main situational characteristics, namely (a) author, (b) addressee, and (c) content/communicative purpose. We will see that with each of them it is necessary to bring some nuance to their proposed position on the register-continuum. Figure 1 only provides a necessary starting point, and can be considered a crude generalization.

\footnotetext{
14) Note that even within one and the same text we can have register variation. As O'Donnell (2000:277) notes: "on the whole, the New Testament is closest to the non-literary variety, though parts might be considered vulgar (e.g. Revelation), while others could be seen as close to literary (e.g. Hebrews)".

15) The only text which is less easily classified under one of these three groups is the Septuagint, which I have also included in the investigation (being one of the major linguistic sources for the Early Post-classical period).
} 


\subsection{Non-Literary (Documentary) Papyri}

Contrary to biography/hagiography and historiography, the papyri are nonliterary, a fact which (to a large extent) explains why we find them at the left of the continuum. Conventionally, the documentary papyri are divided into two main groups (and then further sub-divided, see Palme 2009) on the basis of addressee: 'private' (e.g. private communications, records of transactions, documents of piety) versus 'public' (e.g. petitions to officials, tax receipts, pronouncements of the government/administration). While private documents are generally taken to be written by ordinary people in an 'unpretentious' language, we must be careful not to overgeneralize. For one thing, private documents with an 'official' character were often written in a more formal register. ${ }^{16}$ Moreover, even in the case of the private letters, the educational level of the author could greatly vary (Salonius 1927:3).

\subsection{Historiographical Texts}

At the other end of the continuum, we find the historiographical texts. Indeed, the differences with regard to the three above-mentioned situational characteristics could not be greater: the authors of these texts were well educated, writing about the glorious political/military deeds of the past, directing their work at an 'educated, international public' (Adrados 2005:196). Again, however, some nuance is necessary. A distinction which is commonly made (see e.g. Rosenqvist 2007:10-13) is that between (more traditional) historiographical works, which in the line of Herodotus and Thucydides try to give an impartial treatment of shorter periods of time, and so-called 'chronicles', which start with the creation of the world and continue to the time of the author, often with the purpose of showing the hand of God in historical events. ${ }^{17}$ Works of the second type (in our case, the chronicles of John Malalas and Theophanes Confessor, next to the so-called Paschal Chronicle) were generally written in a less elevated language than the (often) classicizing histories (see Rosenqvist 2007:18 with regard to Malalas). Even with the first type of texts, however, there were some authors who wrote in a lower register (Polybius being a well-known example, see e.g. Horrocks 2010:96).

16) In this context, Mandilaras (1972:10), discussing the language of the papyri, makes a broad distinction between two types of language, that is, 'the official language' (official and business documents) and the 'popular language' (private letters), observing with regard to the former that "this form of the language is in general artificial, characterized by repetitions, and built on stereotyped expressions which are always found in the bureaucratic system".

17) According to Rosenqvist (2007:10) so-called 'church histories' constitute a third type, but this will not further concern us here. 


\subsection{Biographical/Hagiographical Texts}

The third group, which I have situated towards the middle of the register-continuum, is the most disparate with regard to the above-mentioned situational characteristics. In comparison with historiography, biographical/hagiographical texts did not aim at recounting the glorious events of the past, but rather focused on a single personality (Cox 1983:12). ${ }^{18}$ Since most of these texts are written in a much lower register than the historiographical ones (see Høgel 2002:25 "an idea of simplicity permeated hagiography"), it would seem that they were directed at a much broader audience (readers and listeners!), including people from the general populace (Høgel 2002:30). Their authors could belong to the lower strata of society, but the picture is diverse (in any case, we must take into account that these authors were literate, which was a privilege in se): they were written by followers of the saints, monks, deacons, and occasionally even by people with a very high social position, such as the patriarch Athanasius (Høgel 2002:29).

Several remarks are in order. Firstly, the corpus also contains a selection of Plutarch's pagan biographies, which were written in the high register (since Plutarch adopted the 'chronological' rather than the 'topical' mode for his biographies (Cox 1983:56), his work is much closer to historiography anyway). Secondly, as can be seen in the appendix, biography/hagiography does not constitute a uniform genre: the corpus contains acts, apocalypses, gospels, encomia, homilies, miracles, laudations, lives and passions. Of these, especially the encomia, homilies and laudations (i.e. subgenres concerned with praise) are more rhetorically elaborated (see Høgel 2002:22) and hence positioned more to the right of the register-continuum. Thirdly, the genre itself was subject to diachronic changes: when in the fourth century Christianity received imperial support, the Cappadocian fathers (who were highly educated) did not write 'simple language', but adopted the "style, form and vocabulary of their own earlier training” (Cameron 1991:111), even in hagiography..$^{19}$ As a result, biographi$\mathrm{cal} /$ hagiographical texts "ranged over the entire literary spectrum and appealed to readers of all educational levels" (Cameron 1991:147).

Data have been collected on the basis of two online (lemmatized) databases, the Thesaurus Linguae Graecae (TLG) ${ }^{20}$ (biography/hagiography and histori-

\footnotetext{
18) See already Plutarch, Pompeius 8.6.

19) As Høgel (2002:27) notes, however, high-register hagiographical texts are mostly confined to the fourth and seventh/eighth centuries (with authors such as Sophronius, Gregory the Presbyter, Ignatius the Deacon, and Stephan the Deacon).

20) At http://stephanus.tlg.uci.edu (University of California).
} 
ography) ${ }^{21}$ and the Duke Databank of Documentary Papyri (DDBDP, version 2010 $)^{22}$ (papyri). While these are invaluable resources for large-scale diachronic research, it must not be forgotten that they have their limitations. The main disadvantage of the TLG is that it does not display the critical apparatus. Recent research, however, has emphasized the importance of taking into account these variants for diachronic linguistic research (see e.g. Fleischman 2000; Manolessou 2008). A limitation of the DDBDP is that it does not mention the number of words for each text (which, undoubtedly, is to be attributed to the nature of these documents), as a result of which it is not possible to provide normed rates of occurrence when discussing the papyri. To get a rough image of the number of papyri per period studied, we can rely on the study of Habermann (1998), ${ }^{23}$ according to whom the Early Post-classical papyri represent $20 \%$ of the total number of papyri, the Middle Post-classical ones almost $50 \%$, the Late Postclassical ones $23 \%$ and the Early Byzantine ones only $7 \%$ (the low percentage of Early Byzantine papyri being due to the fact that Egypt fell into Arab hands in the seventh century $\mathrm{AD}$, whereby Arabic became the dominant language in the region).

\section{The Diachrony of Perfect Periphrases with sipi and है $\chi \omega$ in Post-Classical and Early Byzantine Greek}

\subsection{Early Post-Classical Greek (III-IBC)}

4.1.1. Ei $\mu$ i with Perfect Participle: Dominant Perfect Periphrasis

As in Classical Greek (henceforth abbreviated as CG), eipi (eimi) with perfect participle constitutes the dominant perfect periphrasis in the EPG period. The general characteristics of the construction (with regard to frequency of occurrence, aspectual semantics and morphology) are much the same, though there are some small differences (especially in the middle register).

In table 1, I compare the frequency of occurrence of zi $\mu i$ (eimi) with perfect participle (normed rate of occurrence or 'NRO' calculated per 10,000 words) in the Early Post-classical texts from our corpus with that in the work of two representative classical authors: ${ }^{24}$

\footnotetext{
21) See appendix for an overview of the literary sources. For the abbreviations of the Post-classical and Early Byzantine texts, I follow Lampe (1976).

22) At http://www.papyri.info (Duke University).

23) For further discussion, see Dickey (2003).

24) The data provided for Xenophon and Demosthenes are taken from Bentein 2012.
} 
Table 1. Frequency of occurrence of sixi with perfect participle in EPG.

\begin{tabular}{lllll} 
Text & Author & Date & Total & $\begin{array}{l}\text { NRO } \\
(/ \mathbf{1 0 0 0 0})\end{array}$ \\
\hline (all works) & Xenophon & V-IVBC & 138 & 4.3 \\
(all works) & Demosthenes & IV BC & 120 & 4.0 \\
Septuagint & & III-II BC & 202 & 3.1 \\
Histories & Polybius & III-II BC & 48 & 1.5 \\
Apocalypse of Enoch & & II-I BC & 4 & $(4.6)$ \\
Roman Antiquities & Dionysius of Halicarnassus & I BC & 67 & 2.3 \\
Life of Adam and Eve & & I BC-IAD & 2 & $(4.3)$ \\
\hline
\end{tabular}

In comparison with Xenophon and Demosthenes, there does not seem to be an increase in frequency in EPG (to the contrary). Note that there may be a register difference, in that the periphrastic perfect seems to be most often used in middle-register texts (the Septuagint, the Apocalypose of Enoch, and the Life of Adam and Eve). It is difficult to make any generalizations, however, as it is not clear to what extent these isolated texts are representative for the entire register (regrettably, the number of middle-register texts in EPG is limited). In any case, Polybius (who, as I have mentioned above, writes in a lower register than the other historiographers) does not seem to follow this trend.

As for the semantics of Eiji (eimi) with perfect participle, scholars such as Aerts (1965) (see §1) and Moser (1988) consider the aspectual range of gi $\mu$ í (eimi) with perfect participle to have been limited to a resultative (i.e. stative) function. Moser for example writes that:

Given that it has been established that the same function, that of denoting a state, appears at both ends of the continuum, Homeric and present-day Greek, and that the हi $\mu \alpha$ c construction is the oldest of the periphrastic forms under investigation, it seems probable that it has always fulfilled this function.

(Moser 1988:229)

Recently, I have argued (Bentein 2012) that such a view must be dismissed as far as CG is concerned. I have shown that the construction was propagated in fifth- and especially fourth-century Greek, with an accompanying increase in frequency. During this period, the aspectual semantics of $\varepsilon i \mu i$ (eimi) with perfect participle shifted from a resultative to an anterior function, similarly to what was the case for the synthetic perfect. In EPG as well, the construction could be used with both aspectual functions. Consider examples (1) (resultative) and (2) (anterior): 25

25) The Greek text of the examples is based on the TLG or the DDBDP. The transliteration follows standard rules, and is not intended to reflect the historical pronunciation. 


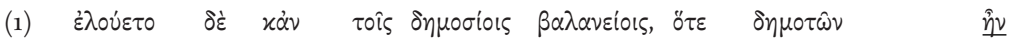
eloueto de kan tois dēmosiois balaneiois, hote dēmotōn $\underline{\bar{e} n}$ he.bathed PTC also.in the public baths when of.common.people it.was

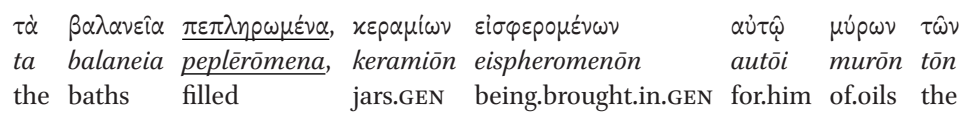
$\pi 0 \lambda v \tau \varepsilon \lambda \varepsilon \sigma \tau \dot{\alpha} \tau \omega \nu$ polutelestatōn most.precious

"he also used to bathe in the public baths, when they were full of common people, having jars of the most precious ointments brought in for him"

(tr. Shuckburgh, modified) (Pol., Hist. 26.1.12)

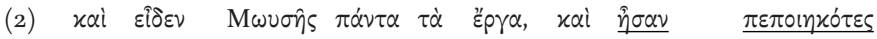

kai eiden Mōusēs panta ta erga, kai ēsan pepoiēkotes

and he.saw Moses all the works and they.were having.done

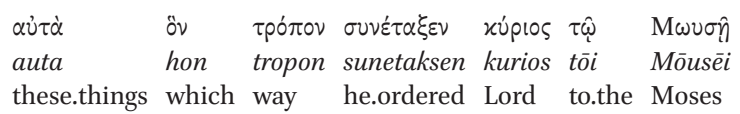

"and Moses saw all the work, and they had done it the way the Lord had ordered Moses"

(ESV, modified) (Ex. 39.23)

While in (1) a property of the subject is indicated (the public baths being full), in (2) the periphrastic perfect denotes a past event that has current relevance at the time of Moses' seeing.

Table (2) gives an overview of the percentage of resultative versus anterior perfects, again in comparison with Xenophon and Demosthenes (in whose work the anterior (periphrastic) perfect came to be fully employed, see Bentein 2012:198-201):

Table 2. Distribution of gini with perfect participle in EPG (aspectual function).

\begin{tabular}{llllll} 
Text & Author & Date & Total & Resultative & Anterior \\
\hline (all works) & Xenophon & V-IVBC & 138 & $70(51 \%)$ & $68(49 \%)$ \\
(all works) & Demosthenes & IV BC & 120 & $30(25 \%)$ & $90(75 \%)$ \\
Septuagint & & III-II BC & 202 & $172(85 \%)$ & $31(15 \%)$ \\
Histories & Polybius & III-II BC & 48 & $24(50 \%)$ & $24(50 \%)$ \\
Apocalypse of Enoch & & II-IBC & 4 & $4(100 \%)$ & o.o \\
Roman Antiquities & Dionysius of Halicarnassus & I BC & 67 & $28(42 \%)$ & $39(58 \%)$ \\
Life of Adam and Eve & & IBC-IAD & 2 & $2(100 \%)$ & o.o \\
\hline
\end{tabular}

This table indicates that the anterior function, which had become predominant in a number of authors in fourth-century Classical Greek (see e.g. Demosthenes), came to be less often employed in EPG. This is most noticeable in three middle-register texts, the Septuagint, the Apocalypse of Enoch and the Life of Adam and Eve (with percentages ranging from 85 to $100 \%$; but note the small 
number of instances in the latter works). However, it is much less the case in the work of Polybius and especially Dionysius of Halicarnassus, where anteriors are equally frequent, or in the majority (here, the percentages resemble those for Xenophon).

One language-internal ecological factor which facilitated the spread of $\varepsilon i \mu i$ (eimi) with perfect participle in CG were morphological difficulties in certain areas of the synthetic paradigm, most importantly the passive perfect and pluperfect indicative (third person), the (active/)passive subjunctive and optative and the active(/passive) future perfect indicative (see e.g. Smyth 1984[1920]: 182-183, 198-199). In these domains, the periphrastic perfect presented an alternative formation, which came to be paradigmatically integrated. Table (3) shows the distribution of eipi (eimi) with perfect participle with regard to mood in EPG, in comparison again with Xenophon and Demosthenes:

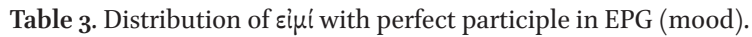

\begin{tabular}{|c|c|c|c|c|c|c|c|c|c|}
\hline Text & Author & Period & Total & IMP & IND & INF & OPT & PART & SUBJ \\
\hline (all works) & Xenophon & V-IV вС & 138 & o & $\begin{array}{l}85 \\
(62 \%)\end{array}$ & $\begin{array}{l}2 \\
(1 \%)\end{array}$ & $\begin{array}{l}29 \\
(21 \%)\end{array}$ & o & $\begin{array}{l}22 \\
(16 \%)\end{array}$ \\
\hline (all works) & Demosthenes & IV BC & 120 & o & $\begin{array}{l}73 \\
(6 o \%)\end{array}$ & $\begin{array}{l}1 \\
(1 \%)\end{array}$ & $\begin{array}{l}27 \\
(23 \%)\end{array}$ & o & $\begin{array}{l}19 \\
(16 \%)\end{array}$ \\
\hline Septuagint & & III-II вC & 202 & $13(7 \%)$ & $\begin{array}{l}169 \\
(84 \%)\end{array}$ & $\begin{array}{l}2 \\
(1 \%)\end{array}$ & $\begin{array}{l}7 \\
(3 \%)\end{array}$ & o & $\begin{array}{l}11 \\
(5 \%)\end{array}$ \\
\hline Histories & Polybius & III-II вC & 48 & o & $\begin{array}{l}32 \\
(67 \%)\end{array}$ & $\begin{array}{l}3 \\
(6 \%)\end{array}$ & $\begin{array}{l}6 \\
(13 \%)\end{array}$ & o & $\begin{array}{l}7 \\
(14 \%)\end{array}$ \\
\hline $\begin{array}{l}\text { Apocalypse } \\
\text { of Enoch }\end{array}$ & & II-I вC & 4 & o & $\begin{array}{l}4 \\
(100 \%)\end{array}$ & o & o & o & o \\
\hline $\begin{array}{l}\text { Roman } \\
\text { Antiquities }\end{array}$ & $\begin{array}{l}\text { Dionysius of } \\
\text { Halicarnassus }\end{array}$ & I BC & 67 & $1(1 \%)$ & $\begin{array}{l}57 \\
(86 \%)\end{array}$ & $\begin{array}{l}2 \\
(3 \%)\end{array}$ & $\begin{array}{l}6 \\
(9 \%)\end{array}$ & $\begin{array}{l}1 \\
(1 \%)\end{array}$ & o \\
\hline $\begin{array}{l}\text { Life of Adam } \\
\text { and Eve }\end{array}$ & & IBC - IAD & 2 & o & $\begin{array}{l}2 \\
(100 \%)\end{array}$ & o & o & o & o \\
\hline
\end{tabular}

Key: 'IMP' = imperative; 'IND' = indicative; 'INF' = infinitive; 'OPT' = optative; 'PART' = participle; 'SUBJ' = subjunctive.

Here we see that much more so than in CG, sipi (eimi) with perfect participle is used in the indicative mood (a tendency which is again most clear in middleregister works, i.e. the Septuagint, the Apocalypse of Enoch and the Life of Adam and Eve; but note the low degree of subjunctives in Dionysius of Halicarnassus' Roman Antiquities). One mood which is more often used than in CG is the imperative (in Classical and Archaic Greek there are only ten examples; Bentein 2012:200). As this table indicates, almost all of the examples can be found in the Septuagint. ${ }^{26}$

26) See e.g 2 Chron. 6.40; Gen. 27.33; Ex. 28.20; 3 Kings 8.52; Prov. 3.5; Sir. 5.10. Cf. also Dion. Hal., Ant. Rom. 4.6.4. 
4.1.2. The Ptolemaic Papyri: Periphrasis and Formulaicity

In the Ptolemaic papyri, zipi (eimi) with perfect participle is particularly well attested, more so than in any of the other periods under discussion: the examples (of zipi (eimi) with perfect participle) from this period account for $55 \%$ of all papyrological examples $(282 / 510)$. Since according to the study of Habermann (1998) the Ptolemaic papyri represent (only) $20 \%$ of the total number of papyri, this can be taken as a clear indication of the overall productivity of the construction in this period of the language. From a semantic and morphological point of view, the use of the construction in the papyri is comparable to that in the literary texts. There are some noticeable divergences, but we will see that these can be attributed to the influence of formulaicity.

The construction is mostly used in the indicative $\operatorname{mood}(72 \%(=202 / 282))$. However, it also occurs in the optative and especially subjunctive mood (and

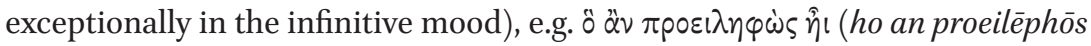
$\bar{e} i$ ) (P.Petr.3.43, fr. 2, 4, 1. 42 (after 245 BC)) "that what he has already received",

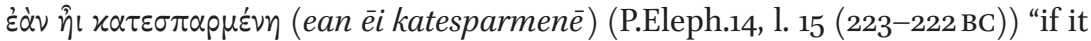

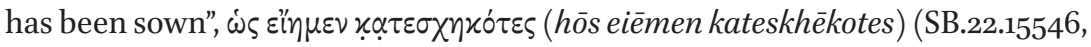
1. 9 (II BC) ) "that we have gained possession of". Much more so than in the literary texts, the construction is used in the future tense $(98 / 282=35 \%(!))$, e.g. [

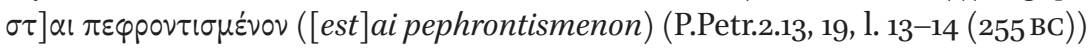

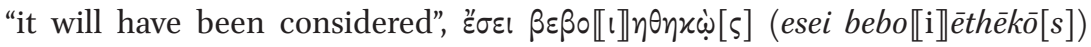

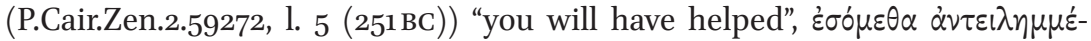
Vor (esometha anteilèmmenoi) (BGU4.1193, 1. 13-14 (8 BC)) "we will have been helped". Surprisingly, the construction is more often attested in persons other than $3 \mathrm{SG} / \mathrm{PL}$ (the latter only represent $40 \%(114 / 282))$, 1 SG being especially well

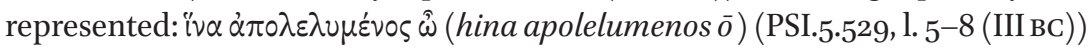

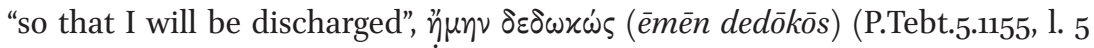

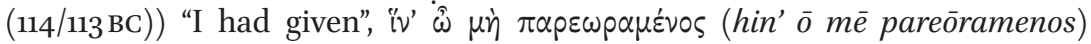
(BGU.8.1830, l. 6 (51 BC)) "so that I will not have been neglected".

Semantically, both resultative and anterior perfects are well attested, dismissing the view that periphrastic si $\mu$ i ( eimi) with perfect participle would have been restricted to a 'stative' aspectual function. Some resultative examples, where the participle indicates a property of the subject, are: (about a wall) $\pi \varepsilon \pi \tau \omega x o ́ \varsigma ~ \varepsilon ่ \sigma \tau \iota \nu$ (peptōkos estin) (P.Petr.2.13, 3, l. 3 (255 BC)) "it is ruined", (about peasants) $\alpha^{\prime} \nu \tau i \nu \varepsilon \varsigma$

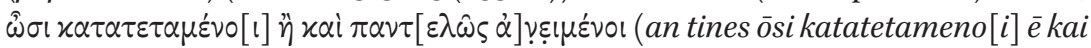
pant [elōs a]neimenoi) (P.Tebt.3.1.703, 2, 1. 60-61 (ca. 210 BC)) "if some are hard pressed or even completely exhausted", (about one's eyes) $\kappa \varepsilon x \lambda \varepsilon เ \mu[\varepsilon$ 'vol] $\hat{\eta} \sigma \alpha \nu$ (kekleimenoi èsan) (UPZ.1.78, 1. 6-7 (after 159 BC)) "they were closed". In various other examples, the construction has an anterior function. Such anterior perfects are used in situations where a past event has current relevance, such as a theft in (3): 


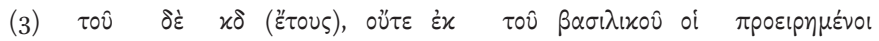

tou de $k d$ (etous), oute ek tou basilikou hoi proeirēmenoi

in.the PTC 24 year nor from the Treasury the aforementioned

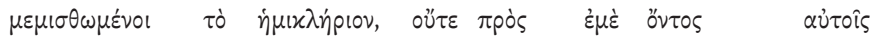

memisthōmenoi to hèmiklērion, oute pros eme ontos autois

having.rented the half.a.lot nor towards me existing.GeN for.them

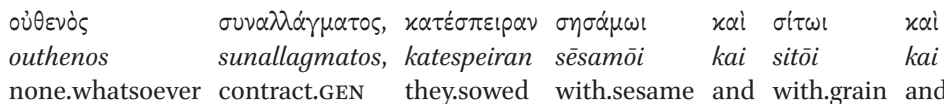

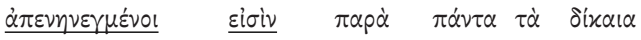

apenènegmenoi eisin para panta ta dikaia

having.taken.away they.are against all the justice

"in the year 24 the aforementioned, without having rented half of the lot from the Treasury, and without there being any contract with me, have sown it with sesame and grain, and have brought in the harvest against all justice"

(tr. Guéraud, originally in French) (P.Enteux.55, 1. 7-9 (222 BC))

When considering these morphological and semantic findings we must take into account the influence of formulaicity. One type of expression which occurs

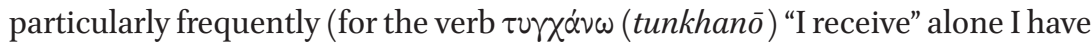
found 85 instances) is generally found towards the end of the text, before the closing formula. It stresses the fact that if this or that has been done (i.e. the question or request found in the main body of the text), the writer will have been greatly helped by the addressee. ${ }^{27}$ Typically, the content verbs used in

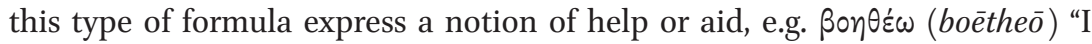

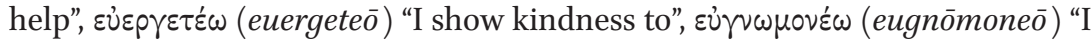

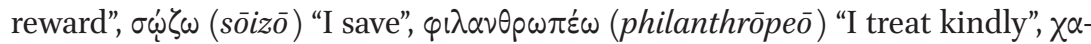
pi $\zeta \omega$ (kharizō) "I show somebody a favor" etc., which is most often passivized ("I will have been ..."). ${ }^{28}$ Alternatively, a verb such as $\tau \vartheta \gamma \chi \alpha \dot{\alpha} \omega \omega($ tunkhanō) or $\mu \varepsilon-$ $\tau \alpha \lambda \alpha \mu \beta \alpha \dot{\alpha} \omega$ (metalambanō) "I receive" could be used with a genitival complement, as in (4). In this papyrus a certain woman called Crateia addresses the

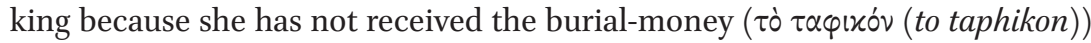
for her brother Apollodotus from Philippus and Dionysius.

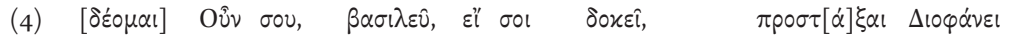
[deomai] oun sou, basileu, ei soi dokei, prost [a]ksai Diophanei I.ask so of.you king.Voc if to.you it.seems.good to.order to.Diophanes

27) This particularly concerns the petitions. As White (1972: xii) notes, reference to "anticipated justice the petitioner will receive if the request is granted" was a structural part of petitions.

28) Another, less often employed, alternative consists in using a verb expressing a notion of neglect

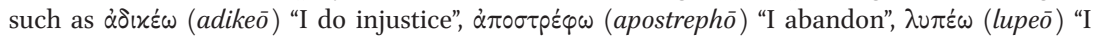
grieve", $\pi \alpha \rho \circ \rho \alpha \omega$ (parorāo ) "I disregard", which is then negated and passivized ("I will not have been ..."). 


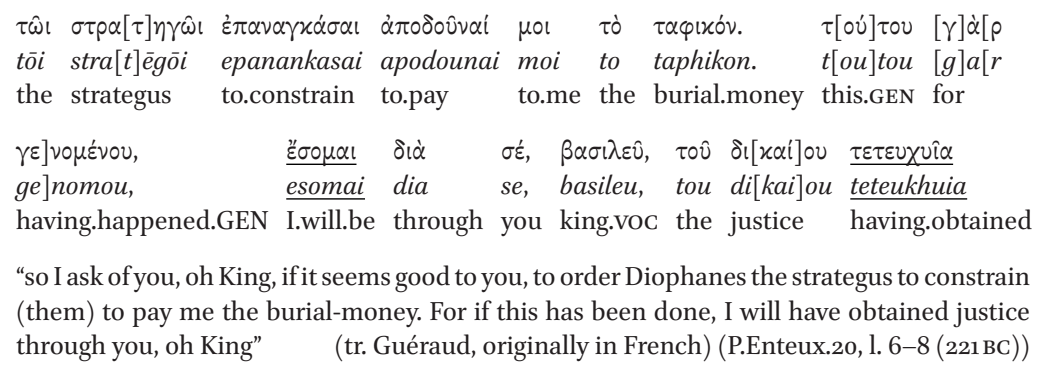

"so I ask of you, oh King, if it seems good to you, to order Diophanes the strategus to constrain (them) to pay me the burial-money. For if this has been done, I will have obtained justice through you, oh King” (tr. Guéraud, originally in French) (P.Enteux.20, 1. 6-8 (221 BC))

The use of periphrastic constructions in this type of expression accounts for more than half of the papyrological examples. This explains some of the remarkable features which I have mentioned above, that is, the frequent employment of the construction in the first or second person, in the future, in the subjunctive mood, and with an anterior function.

\subsubsection{Eiนi with Perfect Participle in the Septuagint: Hebrew Interference?}

As Table 1 shows, most of the examples of giji (eimi) with perfect participle can be found in the Septuagint. In this context, we must ask ourselves to what extent the Hebrew model could have exerted an ecological pressure on the use of periphrastic perfects in Greek. The task at hand is facilitated by recent research of Evans (2001), who in his book on verbal syntax in the Greek Pentateuch dedicates an entire chapter to the use of periphrastic constructions. In his analysis of Hebrew interference, Evans (2001:250) distinguishes between different degrees of structural motivation, proposing a division between three broad translation-technical categories. The first of these is most clear, and comprises Hebrew constructions which bear an obvious structural affinity to periphrastic

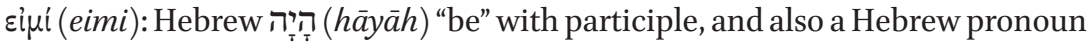
or particle (e.g. הִּנֵּה (hinnēh) "behold") combined with the participle. ${ }^{29}$ The sec-

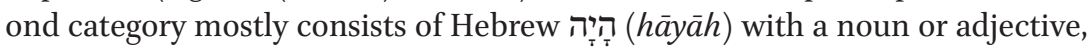
while the third refers to freely used Greek periphrases. In illustration, consider the following examples:

\section{Category 1}

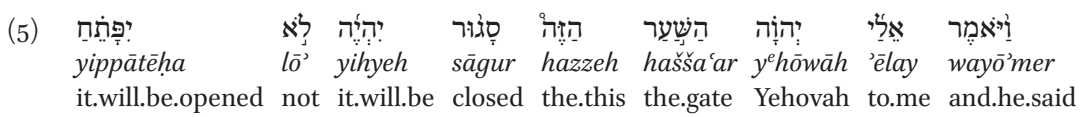

29) Constructions consisting of a Hebrew pronoun or particle combined with a participle already show a lesser degree of structural affinity with Ancient Greek giji (eimi) with perfect participle. 


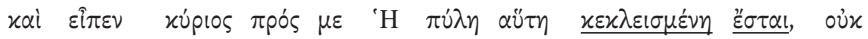

kai eipen kurios pros me hē pulē hautē kekleismenē estai, ouk

and he.said Lord to me the gate this closed will.be not

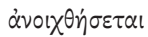

anoikhthēsetai

it.will.be.opened

"and the Lord said to me, 'This gate shall be shut, it shall not be opened'"

(ESV, slightly modified) (Ez. 44.2)

\section{Category 2}

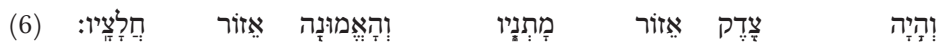

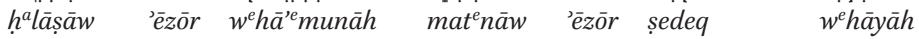

of.his.reins girdle and.faithfulness of.his.loins girdle righteousness and.it.will.be

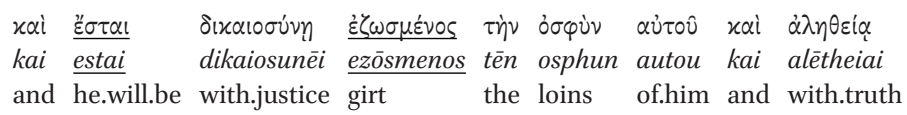

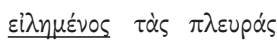

eilèmenos tas pleuras

covered the sides

"and he shall have his loins girt with righteousness, and his sides clothed with truth"

(tr. Brenton) (Isa. 11.5)

\section{Category 3}

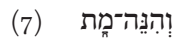

whinnēh-mēt 'et-beni lehēniq babbōqer wä’āqum

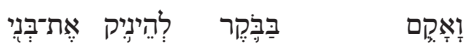

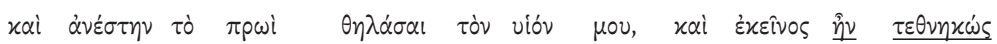

kai anestēn to prōi thēlasai ton huion mou, kai ekeinos ền tethnēkōs

and I.rose the morning to.suckle the son of.me and he was dead

"and I arose in the morning to suckle my son, and he was dead" (tr. Brenton) (1Kings 3.21)

In (5) we encounter the highest degree of structural similarity: Hebrew יִֶֶּי

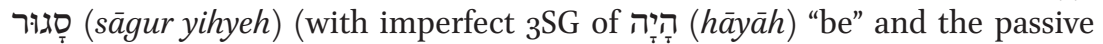
participle (qal-formation) of סָג (sāgar) "to close") is translated by Greek $\chi \varepsilon$ -

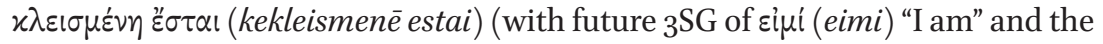
passive perfect participle of $\chi \lambda \varepsilon^{i} \omega$ (kleiō "I close"). Example (6) is representative of the second category, with a lesser degree of structural affinity: Hebrew

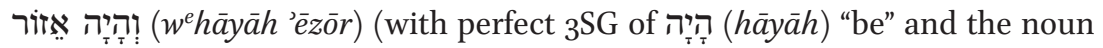
רז' "girdle" ('èzōr), which is repeated twice (lit. "righteousness shall be the girdle ... faithfulness shall be the girdle ...")) is translated by Greek है $\sigma \tau \alpha \mathrm{l} . .$. हे-

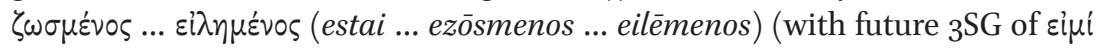

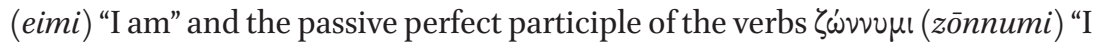


girdle" and $\varepsilon^{\prime} \lambda \omega($ eilō ) "I cover" (lit. "he shall be girdled with ... he shall be covered with")). The third category is illustrated in (7): here the synthetic Hebrew form מֶֶ (mèt) (perfect 3 SG (qal-formation) of the verb (mut) "to die")

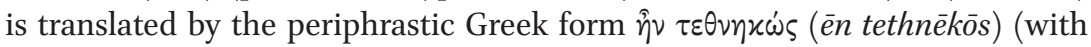

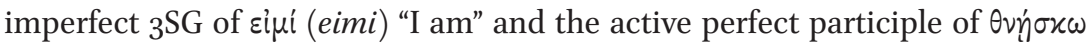
(thnēiskō) "I die").

Having compared all Greek periphrastic forms with their Hebrew equivalent (so not taking into account the deuterocanonical/apocryphal books included in the Greek Septuagint), we find that 55 out of a total of 140 examples, or $39 \%$, is directly influenced by the Hebrew original (corresponding to Evans' first category). ${ }^{30}$ From this category, almost one-third of the Hebrew examples

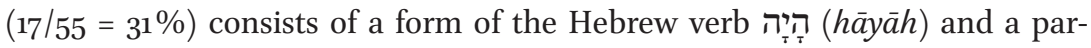
ticiple of the qal stem-formation. ${ }^{31}$ I have found 10 examples $(=7 \%)$ where there is some structural affinity (corresponding to Evans' second category) ${ }^{32}$ and a further $75(=54 \%)$ which show no structural influence whatsoever (corresponding to Evans' third category) ${ }^{33}$ In other words, about half of the examples are structurally influenced while the other half constitute free formations (46 versus $54 \%) .{ }^{34}$ The presence of similar formations in the Hebrew original will undoubtedly have stimulated the use of periphrasis in Ancient Greek, though the construction clearly had acquired an independent status. This is also stressed by Thackeray (1909:195), who writes that "periphrasis in the perfect goes back to the earlier language".

\subsubsection{First Order Variation: Alternative Periphrastic Perfect Constructions}

I have argued that sipi (eimi) with perfect participle can be considered the dominant periphrasis in EPG, in continuation of CG. Nonetheless, my corpus also contains a number of alternative perfect constructions, which occur much less frequently and fall under the heading of Croft's 'first order variation' (see § 2.2). From an ecological-evolutionary perspective, the occurrence of such constructions, which have received very little scholarly attention, is hardly unexpected.

\footnotetext{
30) See e.g. 1Chron. 19.5; Gen. 20.3, 40.6; Isa. 37.10; Jer. 40.1; Josh. 7.22; Job 1.21; 1 Kings 12.6, 13.24; 2 Kings 15.11; Mal. 1.7; Prov. 7.11; Pss. 121.2; 2 Sam. 10.5.

31) These qal-participles are mostly passive, see e.g. 2 Chron. 6.20; Lev. 13.45; Ruth 2.19; 1 Sam. 25.29.

32) See e.g. Gen. 41.36; 2 Esdr. 4.22; Ex. 12.6; Isa. 11.5 (x2), 33.12; Jer. 51.14; Judg. 8.11; 1Sam. 4.13; Zach. $3 \cdot 3$.

33) See e.g. 2 Chron. 5.11; Dan. 6.4, 10.9; Ex. 21.36, 33.13; Ezech. 22.18, 24.17; Gen. 6.12, 43.9; Isa. 10.20, 17.8; Jer. 13.7, 20.1; Job 31.5; Josh. 10.6; Lev. 14.46; Num. 5.13, 5.27; Prov. 3.5; Pss. 71.17; 1 Sam. 14.23.

34) Evans (2001:256) presents slightly different numbers (first category $57 \%$, second category $28 \%$, third category $15 \%$ ), but his research also takes into account other types of periphrases, and is restricted to the Pentateuch.
} 
With the exception of है $\chi \omega(e k h \bar{o})$ with aorist (perfect) participle, the motivation for all of these innovative constructions can be found in what Croft (2000) calls intraference (see § 2.3), i.e. the formal extension of an already familiar construction (e.g. using the aorist in stead of the perfect participle).

\subsubsection{Eipi with Aorist Participle (Anterior/Resultative)}

Both Björck and Aerts locate the first Post-classical instances of this construction in MPG (according to Björck 1940:77 in the NT (Lc. 23.19), while according to Aerts 1965:81, 90 (who rejects Lc. 23.19) in the first/second centuries AD). However, examples can already be found in EPG, though with only eight instances the use of this construction is (still) very infrequent (even in comparison with the other innovative constructions). Examples can be found in Polybius, Dionysius of Halicarnassus, and (a single instance) in the life of Adam and Eve. Semantically, these (and other) examples are much more straightforward than what is the case in CG, where the construction was used both with a perfective and a more perfect-like value (for further discussion, see Aerts 1965:27-35). The Postclassical use can be compared more directly to that of ei $\mu i$ (eimi) with perfect participle: either to indicate a state/property of the subject (i.e. with a resultative function), as in (8), or to refer to an event which happened in the past and has current relevance at a later time (i.e. with an anterior function). ${ }^{35}$

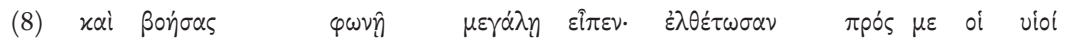

kai boēsas phōnēi megalēi eipen. elthetōsan pros me hoi huioi

and having.shouted with.voice great he.said let.them.come to me the sons

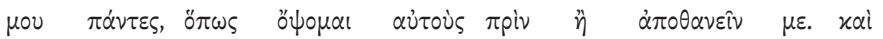

mou pantes, hopōs opsomai autous prin $\bar{e}$ apothanein me. kai

of.me all so.that I.will.see them before that to.die me and

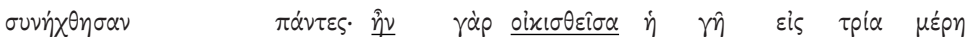

sunēkhthēsan pantes. $\underline{\bar{e} n}$ gar $\underline{\text { oikistheisa }}$ hè gē eis tria merē they.gathered.together all it.was for divided the earth into three parts

"he cried with a loud voice and said: 'Let all my sons come to me that I may see them before I die.' And all assembled, for the earth was divided into three parts"

(tr. Charles) (V.Ad. et Ev. 5.2-5)

\subsubsection{2. siui with Passive Present Participle (Resultative)}

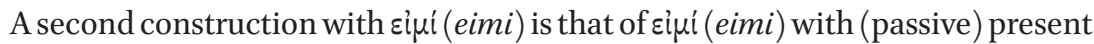
participle (which, surprisingly, is mentioned by none of the major treatments on periphrasis in Ancient Greek) ${ }^{36}$ This construction is quite similar to that

\footnotetext{
35) For additional examples, see e.g. Dion. Hal., Ant. Rom. 2.23.6 (x2), 8.64.2, 9.6o.1, 10.13.3; Pol., Hist. 10.2.2, 11.12.1.

36) To the best of my knowledge, the interchangeability of the present and perfect participle
} 
with the aorist participle: it provides an innovative alternative for ei $\mu$ i (eimi) with perfect participle (motivated through intraference), though (contrary to giji (eimi) with aorist participle) being semantically restricted to the resultative function. In illustration, consider example (9):

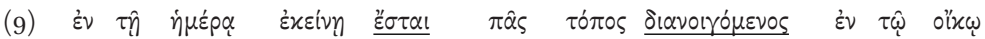

en tēi hēmerai ekeinēi estai pas topos dianoigomenos en tōi oikōi

in the day this it.will.be every place (being).opened in the house

$\Delta \alpha v i \delta$

David

of.David

"in that day every place shall be opened to the house of David" ～(tr. Brenton) (Zach. 13.1)

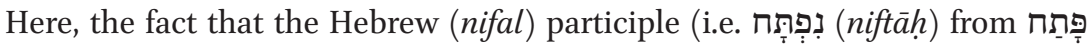
(pātah) "to open") does not distinguish between tenses in the same way Ancient Greek does (i.e. perfect versus present participle) may have stimulated the choice for an expressive alternative. However, the construction can also be found in other texts, such as the Apocalypse of Enoch and Dionysius of Halicarnassus' Roman Antiquities. ${ }^{37}$ An example from the latter work is given in (10):

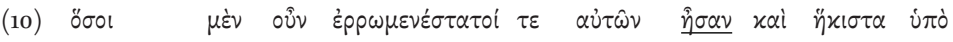
hosoi men oun errōmenestatoi te autōn ēsan kai hēkista hupo
as.many.as PTC so strongest PTC of.them were and least by

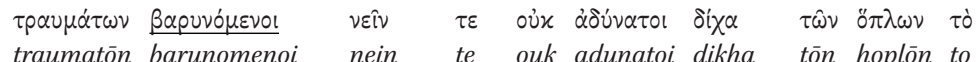 wounds (being).disabled to.swim and not unable without the arms the

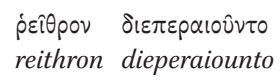

"accordingly, those among them who were strongest, least disabled by their wounds, and had some ability to swim, got across the river, without their arms"

(tr. Carry) (Dion. Hal., Ant. Rom. 3.25.4)

Here, the co-ordination of the participle ßapuvó $\mu \varepsilon v o r$ (barunomenoi) with the

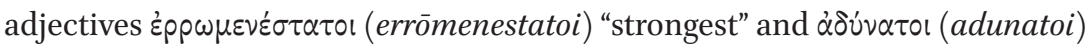
"unable" strongly indicates the stative/resultative value of the participle. ${ }^{38}$

(in general) has been mentioned by only two authors, that is, Ghedini (1937:46o) and Mihevc (1959:115). Interestingly, a similar functional overlap has been observed by Haverling (2009:350, $360-361,407-408)$ in the passive voice of the Latin synthetic present and periphrastic perfect. Haverling (2009:360) notes, however, that "often ... the overlap between the functions of the passive present and the passive perfect is not complete".

37) See e.g. Apoc. En. 14.14, 95.2; Dion. Hal., Ant. Rom. 1.45.3, 8.39.2, 8.40.3.

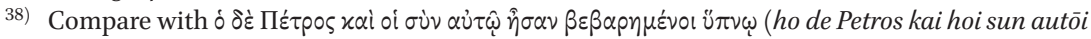
ēsan bebarēmenoi hupnōi) (Lc. 9.32) "Peter and those who were with him were heavy (lit. weighed 


\subsubsection{3. "ैं $\chi \omega$ with Active/Middle Aorist (Perfect) Participle (Anterior)}

The construction of $\varepsilon^{\prime} \chi \omega(e k h \bar{o})$ with aorist (perfect) participle first emerged in fifth-century CG, where it was predominantly used as an anterior perfect (the synthetic perfect and periphrastic eiju (eimi) with perfect participle being used (to a large extent) with a resultative function). However, with the rise of alternative expressions for the anterior function, the construction gradually disappeared in the fourth century BC (Aerts 1965:160). It may thus come as a surprise that the construction can still be found in EPG. However, it only occurs in the work of a single author, Dionysius of Halicarnassus, as in (11): ${ }^{39}$

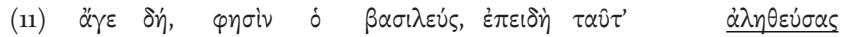

age dē, phēsin ho basileus, epeidè taut' alētheusas

well then he.says the king since these.things having.spoken.truth

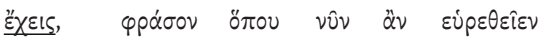

ekheis, phrason hopou nun an heuretheien

you.have say where now PTC they.could.be.found

"well then, since you have spoken the truth about these matters, say where they may now be found"

(tr. Cary) (Dion. Hal., Ant. Rom. 1.82.6)

Since Dionysius is known for his classicizing aspirations, this 'innovative' use must have sprung from his contact with the classical authors, more in particular his wish for imitation.

\subsubsection{4. $\varepsilon^{\prime} \chi \omega$ with Passive Perfect Participle (Resultative (Anterior))}

A second HAVE-perfect occurring in EPG is that of $\varepsilon^{\prime} \chi \omega(e k h \bar{o})$ with passive (and to a much lesser extent active $)^{40}$ perfect participle. It is commonly assumed that this construction first arose in Post-classical Greek (Jannaris 1897:498; Mihevc 1959:141), but this is not quite accurate: it is more correct to say that the construction has never been propagated in CG. Already in Herodotus we encounter instances of this construction, as shown in (12) (cf. Thielmann 1891:305-306). Constructions of this type form an extension of the more regular pattern है $\chi \omega$ $(e k h \bar{o})+$ object + predicative complement.

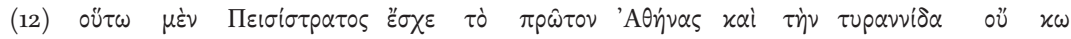
houtō men Peisistratos eskhe to prōton Athēnas kai tēn turannida ou kō so PTC Pisistratus had the first Athens and the sovereignty not yet

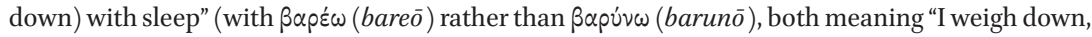
depress").

39) For additional examples, see e.g. Ant. Rom. 6.35.1, 6.36.2, 8.74.2, 9.31.4, 10.31.1, 10.32.2, 10.37.4 (x2), 11.6.4.

40) The variant with the active perfect participle is much less frequent. For ease of reference, I refer to this construction as ' $₹ \chi \omega \omega$ with passive perfect participle' in the remainder of this article. 


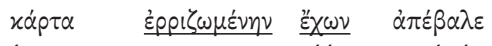

$$
\begin{aligned}
& \text { karta errizōmenēn ekhōn apebale } \\
& \text { verymuch rooted having he.lost }
\end{aligned}
$$

"in this way Pisistratus first got Athens and, as he had a sovereignty that was not yet firmly rooted (lit. having the sovereignty not yet firmly rooted), lost it” (tr. Godley) (Hdt. 1.60.1)

In example (12) $\varepsilon^{\prime} \chi \omega(e k h \bar{o})$ with passive perfect participle has a resultative

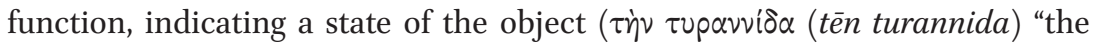
sovereignty"), rather than a past event with current relevance. Similar examples can be found in EPG, as shown in (13) (from the Septuagint):

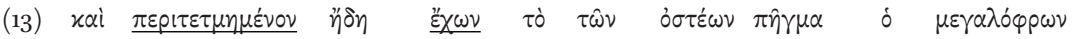
kai peritetmēmenon èdè ekhōn to tōn osteōn pēgma ho megalophrōn and severed already having the of.the bones ligaments the high-minded

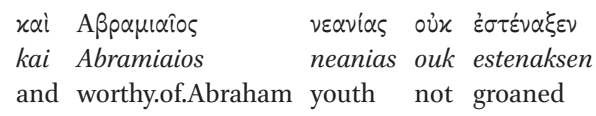

"although the ligaments joining his bones were already severed, the courageous youth, worthy of Abraham, did not groan"

(RSV) (4Macc. 9.21)

It may be clear that the only possible interpretation for $\pi \varepsilon \rho \iota \tau \varepsilon \tau \mu \eta \mu \varepsilon$ vov है $\chi \omega \nu$ (peritetmèmenon ekhōn) is a resultative one: to interpret the example otherwise (i.e. as an anterior) would entail that the youth has severed his own bones. At the same time, however, we find a number of cases which do allow for such an alternative, more agentive interpretation, i.e. as an anterior perfect. Of course, as long as there is concord between the participle and the accusative object, such an interpretation can only come about through pragmatic inference (on which, see Traugott \& Dasher 2002). Consider example (14):

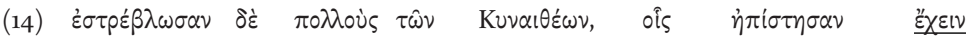 estreblōsan de pollous tōn Kunaitheōn, hois èpistēsan ekhein they.tortured PTC many of.the Cynaetheans whom they.suspected to.have

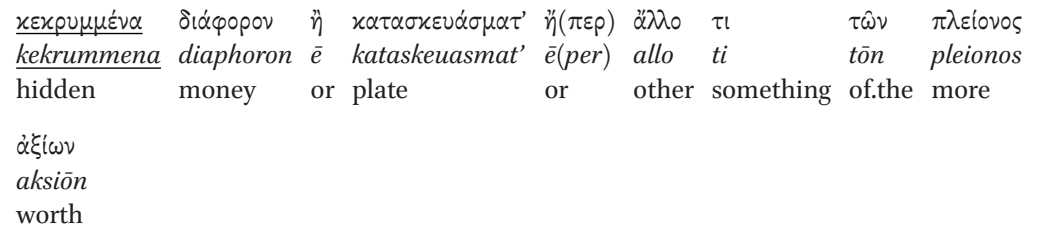
plate, or other valuables"

(tr. Schuckburgh, slightly modified) (Pol., Hist. 4.18.8)

It could be argued that, similarly to our previous examples (12) and (13), the

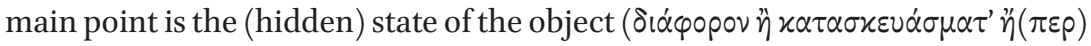
$\alpha \lambda_{\lambda} \mathrm{\tau l}$ (diaphoron è kataskeuasmat' è (per) allo ti) "money, plate, or other valuables"). However, an anterior interpretation (by pragmatic inference) does not 
seem entirely out of the question (contrary to what we have observed for (13)): "they suspected them of having concealed (at an earlier time) money, plate, or other valuables", whereby the subject of है $\chi \varepsilon \vee v ~(e k h e i n)$ is also taken as the agent of the event denoted by the participle (

Almost $60 \%(=23 / 39)$ of the EPG examples ${ }^{41}$ come from Dionysius of Halicarnassus' Roman Antiquities (where we also find $83 \%$ (=10/12) of the examples where an anterior inference would be possible). ${ }^{42}$ This may be related to the fact that Dionysius (6o $\mathrm{BC}$ - after $7 \mathrm{AD}$ ) is on the borderline between two periods (EPG and MPG) (as we will see, in MPG, the construction becomes more frequently attested). We also find two isolated examples in the papyri. ${ }^{43}$

\subsection{Middle Post-Classical Greek (MPG) (I-IIIAD)}

\subsubsection{A Shifting Balance of Power: Functional Specialization of $\varepsilon i \mu i$ with} Perfect Participle

Contrary to what the title of this section may seem to suggest, in MPG eipi (eimi) with perfect participle remains the dominant perfect periphrasis, occurring slightly more frequently than in the previous period (with an NRO of 2.5 per 10,000 words in EPG versus 3 per 10,000 words in MPG (not including the papyri)). What is remarkable, however, is that the construction seems to become more and more functionally specialized towards the expression of the resultative aspectual function. Having encountered the first indications for such a tendency in a number of EPG middle-register texts (the Septuagint, the Apocalypse of Enoch and the Life of Adam and Eve, though not in Polybius), we now find it attested in a broader sample of texts. Consider the data from Table 4:

Table 4. Distribution of eiju with perfect participle in MPG (aspectual function).

\begin{tabular}{llllll} 
Text & Author & Period & Total & Resultative & Anterior \\
\hline New Testament & & IAD & 106 & $76(60 \%)$ & $30(40 \%)$ \\
Parallel lives $^{44}$ & Plutarch & I-IIAD & 41 & $22(54 \%)$ & $19(46 \%)$ \\
Roman Histories & Cassius Dio & II-III AD & 58 & $22(38 \%)$ & $36(62 \%)$ \\
Other (middle-register) texts & & I-III AD & 42 & $35(83 \%)$ & $7(17 \%)$ \\
\hline
\end{tabular}

\footnotetext{
41) Almost half of these examples are formed with verbs of 'drawing up' or 'composing' (in the context of the military), such as ह่x $\dot{\alpha} \sigma \sigma \omega$ (ektassō) "I draw out in battle-order", $\tau \dot{\alpha} \sigma \sigma \omega$ (tassō)

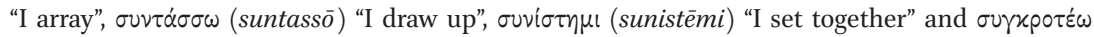
(sunkroteō) "I compose".

42) See e.g. Ant. Rom. 1.46.4, 3.51.1, 6.31.2, 7.17.4, 10.24.3, 10.24.4.

43) See PSI.4.420, 1. 21-23 (III BC) and SB.5.8754, 1. 31 (77 BC).

44) See appendix for the specific selection of lives.
} 
As this table shows, in MPG eipi (eimi) with perfect participle is predominantly used with a resultative aspectual function. In middle-register texts, i.e. the New Testament and other texts (such as the Confession and Prayer of Aseneth, the Testament ofJob and the Acts of Thomas), up to $75 \%(=111 / 148)$ of the examples are used with this function, as in (15) (indicating the open state of the doors):

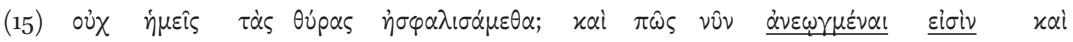
oukh hēmeis tas thuras èsphalisametha kai pōs nun aneōigmenai eisin kai not we the doors fastened and how now opened they.are and

oi $\delta \varepsilon \sigma \mu \omega \hat{\tau} \alpha l$ है $v \delta \delta$;

hoi desmōtai endon

the prisoners inside

"did not we fasten the doors? And how are they now open, and the prisoners within?"

(tr. James) (A. Thom. 122.11-12)

This tendency towards functional specialization is much less clear in Plutarch's Parallel lives (with only $54 \%$ resultatives), and especially in Cassius Dio's Roman Histories (where anteriors form the majority).

Morphologically as well, there is a trend towards reduction, which we have already seen in EPG. Consider the data in Table 5:

Table 5. Distribution of $\varepsilon i \mu i$ with perfect participle in MPG (mood).

\begin{tabular}{|c|c|c|c|c|c|c|c|c|c|}
\hline Text & Author & Date & Total & IMP & IND & INF & OPT & PART & SUBJ \\
\hline New Testament & & $\mathrm{IAD}$ & 106 & $\begin{array}{l}1 \\
(1 \%)\end{array}$ & $\begin{array}{l}89 \\
(84 \%)\end{array}$ & o & o & $\begin{array}{l}4 \\
(4 \%)\end{array}$ & $\begin{array}{l}12 \\
(11 \%)\end{array}$ \\
\hline Parallel lives & Plutarch & I-IIAD & 41 & o & $\begin{array}{l}31 \\
(76 \%)\end{array}$ & $\begin{array}{l}1 \\
(2 \%)\end{array}$ & $\begin{array}{l}7 \\
(17 \%)\end{array}$ & $\begin{array}{l}2 \\
(5 \%)\end{array}$ & o \\
\hline Roman Histories & Cassius Dio & II-III AD & $5^{8}$ & o & $\begin{array}{l}38 \\
(66 \%)\end{array}$ & $\begin{array}{l}1 \\
(1 \%)\end{array}$ & $\begin{array}{l}14 \\
(24 \%)\end{array}$ & $\begin{array}{l}5 \\
(9 \%)\end{array}$ & o \\
\hline $\begin{array}{l}\text { Other (middle- } \\
\text { register) texts }\end{array}$ & & I-III AD & 42 & o & $\begin{array}{l}34 \\
(81 \%)\end{array}$ & $\begin{array}{l}1 \\
(2 \%)\end{array}$ & $\begin{array}{l}4 \\
(10 \%)\end{array}$ & $\begin{array}{l}3 \\
(7 \%)\end{array}$ & o \\
\hline
\end{tabular}

Key: 'IMP' = imperative; 'IND' = indicative; 'INF' = infinitive; 'OPT' = optative; 'PART' = participle; 'SUBJ' = subjunctive.

The only mood in which the periphrastic construction is frequently used is the indicative (cf. Aerts 1965:96). Examples in the subjunctive and optative mood, which formerly (in CG) constituted one of the core areas of the construction, are less often attested. Only the New Testament contains some examples in the subjunctive mood. The only two authors who are fond of the optative mood are Plutarch and Cassius Dio, perhaps not unsurprisingly. ${ }^{45}$ Moreover, it is worth noting that the use of the future tense has almost entirely disappeared (though

45) For some examples, see e.g. Cassius Dio, Hist. Rom. 36.52.4 (x2), 37.38.2, 39.45.3, 41.41.5, 44.15.3; Plutarch, Alex. 27.5, 60.9, 73.3, Dion 21.3, 27.6, Mar. 8.5. 
some examples can be found in the New Testament, as well as Plutarch and Cassius Dio), and that the use of the passive voice for the participle becomes much more frequent, especially in the middle register (with $82 \%(=121 / 148)$ of the examples in the passive voice; contrast with the high register (represented by Plutarch and Cassius Dio), where only $55 \%$ (=54/99) take the passive voice).

The papyri more or less confirm this image. Of course, we must again take into account the influence of formulaic expressions of the kind discussed in $\S$ 4.1.2. With regard to aspectual function, for example, anteriors still abound in formulaic expressions of the type discussed above (note, however, that only $23 \%(=41 / 180)$ of the anteriors do not occur in a formulaic expression). Morphologically as well, formulaic expressions provide a suitable context for the preservation of older uses. Quite contrary to what we have found in the literary texts, for example, the subjunctive mood is well represented with 159 examples (accounting for $77 \%(=159 / 206)$ of the total number of examples (!)), the large majority of which occur in formulaic expressions. Other tendencies do transpire, however. The optative mood is virtually unattested, with only 4 examples. Similarly, the future tense is as good as never adopted: there are only 6 examples, all of which formulaic (quite contrary to what is the case in EPG, with $34 \%$ $(=98 / 282)$ of the examples in the future tense).

How can we explain the (gradual) functional specialization of eipi (eimi) with perfect participle, and its morphological reduction? The ecological-evolutionary framework suggests that specialization is the (possible) outcome of competition with alternative constructions, and this is indeed what we find, as I will show in the following sections. Perhaps more important, however, given the relatively low frequency of occurrence of these alternative constructions, are some broader internal-ecological factors (also from a morphological point of view). Three factors which are of particular relevance are the following: (a) the functional merger of the synthetic aorist and perfect, leading to the disappearance of the latter starting from around the first century вс (see the statistics provided by Duhoux 2000:431); (b) the loss of the optative, partly due to phonetic factors (Mirambel 1966:172); as many scholars have noted, the optative has almost entirely disappeared in the New Testament; and (c) pressure on the formation of (mostly active) participles following the third declension, which may have started as early as the second century BC (Dieterich 1898:206-209; Horrocks 2010:178-183).

\subsubsection{Propagation of Alternative Periphrastic Perfect Constructions: عiłí with Aorist Participle}

While eiji (eimi) with aorist participle occurs very infrequently in EPG, in MPG it can be found in a larger number of texts, as shown in Table 6: 
Table 6. Frequency of occurrence of eiji with aorist participle in MPG.

\begin{tabular}{|c|c|c|c|c|}
\hline Period & Text & Author & Total & $\begin{array}{l}\text { NRO } \\
(/ 10000)\end{array}$ \\
\hline IAD & New Testament (Luke) & & 1 & 0.5 \\
\hline IAD & Papyri & & 1 & 1 \\
\hline II AD & Acts of Andrew & & 2 & 2.1 \\
\hline II AD & Acts of John & & 1 & 0.8 \\
\hline II AD & Gospel of Peter & & 2 & $(16.9)$ \\
\hline II AD & Testament of Job & & 1 & 1.4 \\
\hline II AD & Papyri & & 3 & 1 \\
\hline II-IIIAD & Acts of the Alexandrines & & 1 & 1.5 \\
\hline II-IIIAD & Papyri & & 1 & l \\
\hline II-IIIAD & Roman Histories & Cassius Dio & 4 & 0.1 \\
\hline III AD & Acts of Thomas & & 8 & 2.7 \\
\hline III AD & Acts of Xanthippe and Polyxena & & 2 & 2.1 \\
\hline III AD & Papyri & & 15 & l \\
\hline
\end{tabular}

Here we can see that the propagation of the construction should be situated in the second and especially third century AD. The construction mostly appears in the low and middle register, but, perhaps surprisingly, also surfaces in the work of Cassius Dio (though with a low NRO).

As I have already mentioned in $\S 4.1 .4$, the functional mechanism for this innovation is what Croft calls intraference: the formal extension of a structurally similar construction (in this case eipi (eimi) with perfect participle). This can be looked upon in connection with the development of the synthetic tenses: undoubtedly, the replacement of the perfect participle by an aorist participle will have been stimulated by the syncretization of the synthetic perfect and aorist. Moreover, the fact that the synthetic perfect was losing the competition with the aorist must be considered a language-internal ecological factor stimulating the propagation of $\varepsilon i \mu i$ (eimi) with aorist participle.

In most cases, the construction is used in a discourse context which is typical for the anterior perfect, that is, to provide background-information. In (16), for example, it occurs in an explanatory ráp (gar)-clause:

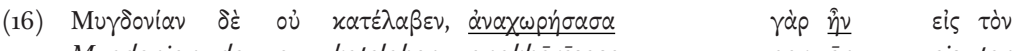
Mugdonian de ou katelaben, anakhōrēsasa gar $\underline{\bar{e} n}$ eis ton Mygdonia PTC not he.found having.withdrawn.herself for she.was to the

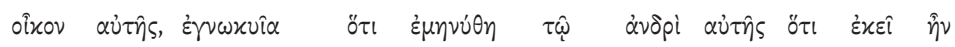
oikon autēs, egnōkuia hoti emēnuthē tōi andri autēs hoti ekei èn house of.her having.learnt that it.was.told to.the man of.her that there she.was "but Mygdonia he did not find, for she had withdrawn herself to her house, having learnt that it had been told her husband that she was there"

(tr. James) (A. Thom. 105.16-18)

However, and this has largely been ignored in the literature (which mostly focuses on the anterior function of giju (eimi) with aorist participle), the con- 
struction could also be used with a stative/resultative function. This mostly concerns passive aorist participles of the kind found in (17), where the coordination with the true adjectives $\sigma \varepsilon \mu \nu \circ u$ s (semnous) "reverent" and $x \alpha \theta \alpha$ poús (katharous) "pure" strongly indicates the property-value of the participle $\dot{\alpha}$ $\pi \alpha \lambda$ ㅅ่ㄴ $\alpha \varsigma$ (apallagentas) "free(d) (from)":

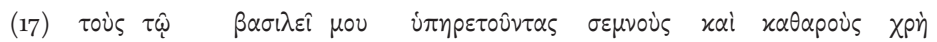

tous tōi basilei mou hupēretountas semnous kai katharous khrē

the for.the king of.me serving reverent and pure it.is.necessary

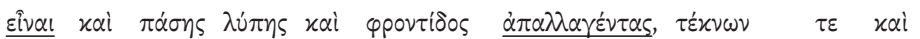

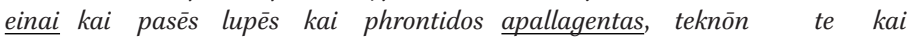

to.be and of.all grief and care freed of.children PTC and

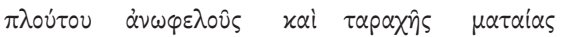

ploutou anōphelous kai tarakhēs mataias

of.wealth unprofitable and of.trouble vain

"they who serve my king must be reverent and pure and free from all grief and care of children and unprofitable riches and vain trouble"

(tr. James) (A. Thom. 126.10-13)

To this must be added cases such as (18) and (19). Here, it would be hard to speak of 'resultative perfects'. Quite surprisingly, in both cases the periphrastic construction indicates a durative event, which is ongoing at reference time.

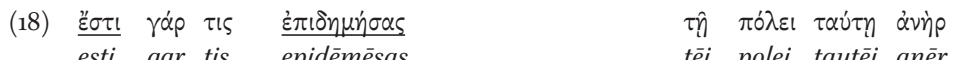

esti gar tis epidēmēsas tēi polei tautēi anēr

he.is for some (having.come.to.stay.in/)staying.in the city this man

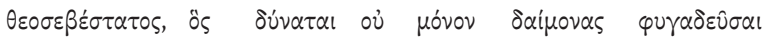

theosebestatos, hos dunatai ou monon daimonas phugadeusai

God-fearing who is.able not only demons to.banish

"for some God-fearing man lives in this city, who is able not only to banish demons ..."

(tr. Prieur, originally in French) (A. Andr. 2.10-12)

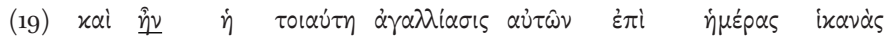

kai ēn hē toiautē agalliasis autōn epi hèmeras hikanas

and it.was the such rejoicing of.them during days considerably.long

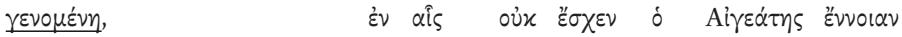

genomenē, $\quad$ en hais ouk eskhen ho Aigeatēs ennoian

(having.happened/)happening in which not he.had the Aegeates thought

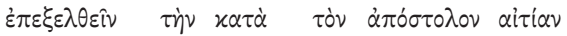

epekselthein tēn kata ton apostolon aitian

to.prosecute the against the Apostle accusation

"and rejoicing of this sort went on for many days, while Aegeates took not thought to prosecute the accusation against the Apostle"

(tr. James, modified) (A. Andr. 34.6-8)

What we are witnessing in these examples is confusion between the different types of participle, which may be related to the difficulties in the formation of 
the active paradigm already referred to (cf. Mirambel 1966:181 for the use of $\varepsilon$ $\mu i$ (eimi) with aorist participle to express "une action en cours de développement").

4.2.3. Propagation of Alternative Periphrastic Perfect Constructions: $\varepsilon^{\prime} \chi \omega$ with Passive Perfect Participle

A second alternative construction which must be mentioned here is $\varepsilon^{\prime} \chi \omega(e k h \bar{o})$ with passive perfect participle. While the construction appears rather infrequently in EPG, in MPG we witness a general increase in frequency (NRO 0.3 in EPG versus 0.7 in MPG (excluding the papyri)). Table 7 gives an overview of the texts in which the construction can be found:

Table 7. Frequency of occurrence of है $\chi \omega$ with passive perfect participle in MPG.

\begin{tabular}{|c|c|c|c|c|}
\hline Period & Text & Author & Total & $\begin{array}{l}\text { NRO } \\
(/ \mathbf{1 0 0 0 0})\end{array}$ \\
\hline $\mathrm{IAD}$ & New Testament & & 12 & 0.8 \\
\hline $\mathrm{IAD}$ & Papyri & & 2 & 1 \\
\hline IAD & Testament of Abraham (rec. B) & & 1 & 3.0 \\
\hline I-IIAD & Papyri & & 1 & 1 \\
\hline I-II AD & Parallel Lives & Plutarch & 21 & 1.3 \\
\hline II AD & Confession and precation of Joseph and Aseneth & & 3 & $3 \cdot 5$ \\
\hline II AD & Papyri & & 4 & 1 \\
\hline II AD & Testament of Job & & 1 & 1.4 \\
\hline II-IIIAD & Roman Histories & Cassius Dio & 12 & 0.3 \\
\hline III AD & Acts of Thomas & & 5 & 1.7 \\
\hline III AD & Papyri & & 4 & 1 \\
\hline
\end{tabular}

Looking at this table, we see that there are two important differences between the rise of $\varepsilon i \mu i$ (eimi) with aorist participle and $\varepsilon^{\prime} \chi \omega(e k h \bar{o})$ with perfect participle: (a) the construction appears in a broader array of texts (in terms of register), and (b) the rise of the construction seems to be situated slightly earlier than that of eijí (eimi) with aorist participle.

When it comes to the expression of the anterior perfect function, we have already seen that the construction of $\varepsilon^{\prime} \chi \omega(e k h \bar{o})$ with passive participle constitutes a special case, as it must be related to pragmatic inference. In such cases, the verb है $\chi \omega(e k h \bar{o})$ loses (part of) its possessive meaning and the context invites us to identify the subject of $\varepsilon^{\prime} \chi \omega(e k h \bar{o})$ as the agent of the event denoted by the participle. Consider example (20):

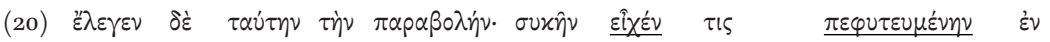
elegen de tautēn tèn parabolēn. sukēn $\underline{\text { eikhen }}$ tis $\overline{\text { pephuteumenèn }}$ en he.said PTC this the parable fig.tree he.had someone planted in 


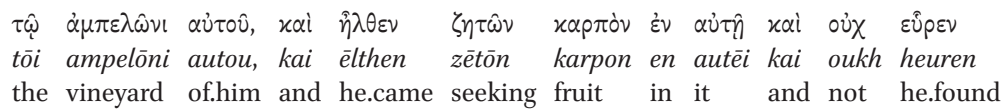

"Jesus then told them this parable: 'a certain man had a fig tree planted in his vineyard, and he came seeking fruit on it, and found none"” $\quad$ (ASV, slightly modified) (Lc. 13.6)

Here, an anterior interpretation (by pragmatic inference, as there is concord between the object, бuxîv (sukēn) "fig tree", and the participle) does not seem entirely out of place; the subject of eix

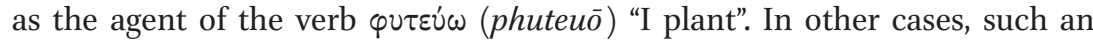
identification of subject and agent is much less evident. In (21), for example, Peina might have bound up her hand herself, but this seems rather unlikely:

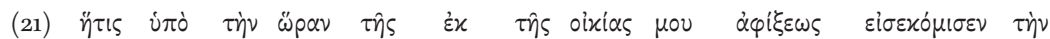
hètis hupo tēn hōran tēs ek tēs oikias mou aphikseōs eisekomisen tēn who at the time of.the from the house of.me departure brought.in the

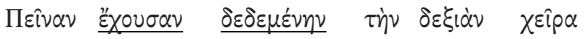

Peinan ekhousan $\underline{\text { dedemenēn }}$ tēn deksian kheira

Peina having bound.up the right hand

“... who at the moment of their departure from my house brought in Peina, who had her right hand bound up" (tr. Bowman, slightly modified) (P.Oxy.50.3555, l. 16-20 (I-II AD))

Given the large degree of context-dependence of $\varepsilon^{\prime} \chi \omega(e k h \bar{o})$ with passive perfect participle, it would seem that - as far as the anterior function is concernedthe construction can be considered a less powerful competitor of eiji (eimi) with perfect participle than the construction of zini with aorist participle.

\subsubsection{HAVE-Perfects in Greek and Latin ${ }^{46}$}

In recent years, a number of scholars have suggested that Greco-Latin language contact as an ecological factor stimulated the development of $\varepsilon^{\prime} \chi \omega(e k h \bar{o})$ with passive perfect participle. In Latin, a structurally similar construction (habeō with passive perfect participle) can be found as early as Plautus, as illustrated in (22) (I borrow this example from Haverling 2009:358):

(22) virtute... et maiorum et tua/ multa bona bene parta habemus by.virtue both of.forebears and yours many means well acquired we.have "thanks to our forebears and yourself, we are well supplied with well-earned means"

(tr. Haverling) (Plaut., Trin. 346-347)

46) For more details on the relationship between the Greek and Latin constructions of HAVE with passive perfect participle, I refer the reader to Bentein forthc. 
Horrocks (2010:132) believes that है $\chi \omega(e k h \bar{o})$ with passive perfect participle ('in an active transitive sense', i.e. what I have called an anterior inference) "is a very strong candidate for classification as a 'Latinism' in the koiné, though not one which made much impact at the time, being alien to the general structure of a still prestigious world language". He furthermore adds that:

This is a wholly unclassical construction, which begins to appear in the more polished
'literary' registers of the Koine in the Roman period (e.g. in the writings of the historian
Diodorus Siculus or the biographer and essayist Plutarch). It is not used by the Atticists, and
it does not appear in low-level literary or subliterary texts. Furthermore, with the advent
of a more stringent Atticist approach in the 2nd century AD, it quickly disappeared even
from stylistically middle-brow compositions, and eventually reappears in popular varieties
of Greek only after the 'Latin' conquest of much of the Byzantine empire after the capture
of Constantinople by the fourth crusade in 1204.
(Horrocks 2010:131-132)

Horrocks' view faces several difficulties. In general, I do not see much reason to limit the discussion to $\varepsilon^{\prime} \chi \omega(e k h \bar{o})$ with passive perfect participle 'in an active transitive sense'. As I have already shown, the anterior function of the construction is clearly related to the resultative one (the latter of which is predominant). Furthermore, the proposed diffusion and chronology are incorrect: (a) Horrocks considers the construction 'wholly unclassical' and 'alien to the general structure of a still prestigious world language'; this seems questionable, as instances of the construction can already be found in CG (cf. § 4.1.4.4); (b) as I have shown above, the first Post-classical instances of this construction (with anterior inference) can be found EPG, in texts of different registers (the Septuagint, Polybius' Histories and Dionysius of Halicarnassus' Roman Antiquities); (c) in MPG, the period on which Horrocks focuses, the construction is hardly confined to what Horrocks calls the 'literary' registers (see again Table 7); (d) the construction continues to be used in LPG and EBG, as is shown below.

Recently, Drinka (2007) has argued for a more complex scenario, claiming that the two languages must have influenced each other in the development of this construction:

1. During the first centuries $\mathrm{BC}$, the Greek construction of $\varepsilon^{\prime} \chi \omega(e k h \bar{o})$ with active/middle aorist participle (cf. $\S 4.1 .4 .3, \S 4.2 .5 .2$ ) was calqued by welleducated Romans such as Plautus and Cato the Elder, "who had the means and the motivation to bring Greek elements into their language" (Drinka 2007:103).

2. However, since the Romans did not dispose of an active/middle aorist participle, they had to use the passive perfect participle, whereby they were forced "to stretch the semantic range of their own participle, causing it to move towards subject-orientation and possible interpretation as an active" (Drinka 2007:103). 
3. At a later stage, i.e. during the first centuries AD, "Greeks may have been imitating prestigious Romans in their use of the HAVE + past passive participle (PPP)" (Drinka 2007:103), as a result of which the construction of है $\chi \omega(e k h \bar{o})$ with active/middle aorist participle was lost.

This alternative scenario cannot be upheld either. With regard to the first two points, we must ask ourselves whether the employment of habeō with passive perfect participle (as a resultative perfect) by Plautus could really have been motivated by a wish for conscious imitation of Ancient Greek $\varepsilon^{\prime} \chi \omega(e k h \bar{o})$ with active/middle aorist participle (used as an anterior perfect). In other words, could his audience really have recognized this literary Graecism? As van Coetsem (2000) has shown, not only does the borrowing of lexical material constitute the more typical case of 'recipient language agentivity', ${ }^{47}$ even if grammatical/phonological material would be transferred (what van Coetsem calls 'the extended mode of borrowing', whereby the source-language is culturally dominant), imitation not adaptation is the rule (the use of the passive perfect instead of the active/middle aorist participle being an instance of adaptation). Moreover, I have great doubts about whether speakers/writers can simply 'stretch the semantic range' of the participle. In any case, whether the semantic range of the participle really has been 'stretched' in the earliest examples is rather questionable; together with most recent treatments of the Latin construction, I would say that it is predominantly stative/resultative, and only occasionally (by pragmatic inference) has an anterior function (contrary to है $\chi \omega(e k h \bar{o})$ with active/middle aorist participle (supposedly imitated), which is mostly used with an anterior function in the Classical texts). As for the third point, I believe that the loss of the construction of $\varepsilon^{\prime} \chi \omega(e k h \bar{o})$ with aorist participle should be dated to the Classical period. Rather than attributing its loss to the rise of है $\chi \omega$ $(e k h \bar{o})$ with perfect participle in the Post-classical period, I argue that it disappeared in the fourth century BC due to the functional extension of the synthetic perfect and periphrastic eipi (eimi) with perfect participle, leaving the construction without a raison d'être.

In my view, Ancient Greek है $\chi \omega(e k h \bar{o})$ with passive perfect participle and habeo with passive perfect participle constitute independent developments, originating from the common pattern HAVE + object + predicate (see Pinkster

\footnotetext{
47) 'Recipient language agentivity' can be defined in terms of 'pull transfer' (van Coetsem 2000:53), e.g. the case of someone whose linguistically dominant (mother-)language is French and when speaking French from time to time adopts an English word. This is to be contrasted with 'source language agentivity', which can be defined in terms of 'push transfer' (van Coetsem 2000:54), e.g. the case of someone whose linguistically dominant (mother-)language is English and tries to speak French, making pronunciation-errors.
} 
1987 for Latin). In both cases, the construction started out as a resultative, from time to time allowing an anterior inference (which in Latin (though not in Ancient Greek), through reanalysis, led to the formation of a true periphrastic anterior perfect). In principle, though, it cannot be excluded that the existence of the construction in one language may have reinforced its use in the other (cf. Drinka 2007:108 "the lack of need for external explanation does not preclude the existence of such influence").

\subsubsection{First Order Variation: Alternative Periphrastic Perfect Constructions}

Next to the constructions discussed above there are several other periphrastic perfect constructions, which fall under the heading of Croft's 'first order variation':

\subsubsection{Eipi with (Passive) Present Participle (Resultative/Anterior)}

We have seen that in EPG the passive present participle could occasionally be used as a (near) equivalent of the resultative passive perfect participle, in combination with sipi (eimi). Such examples are also attested in MPG, though they are infrequent (they mostly occur in the papyri and texts from the middle register, though also in Plutarch). Often it can be difficult to decide whether the passive present participle is semantically 'equivalent' to the perfect participle. For

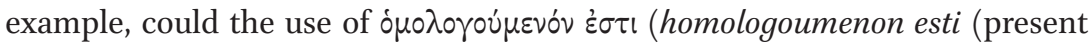

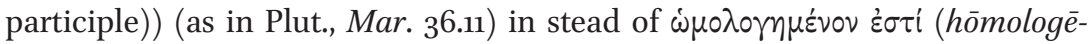
menon esti (perfect participle)), both meaning "it is acknowledged", have been motivated by the wish to stress the current validity of the statement?

In an example such as (23) we find more direct evidence of the interchangeability of the passive perfect and present participle:

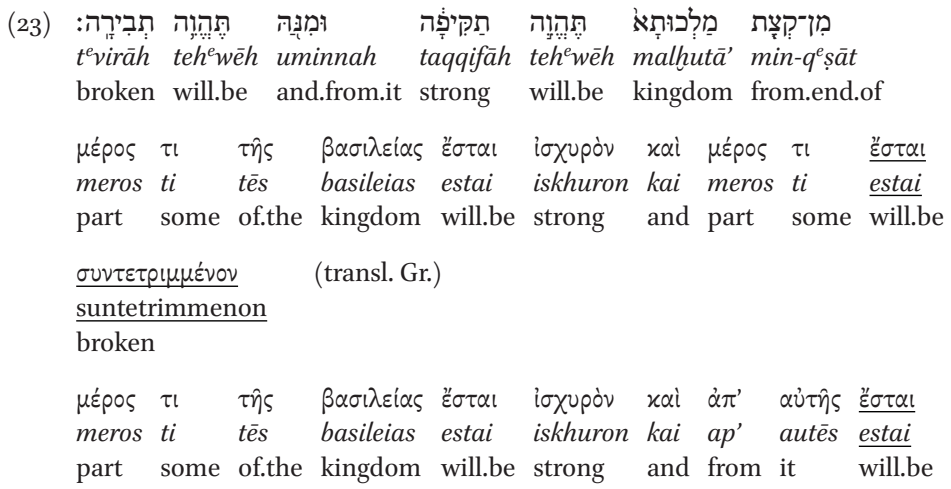




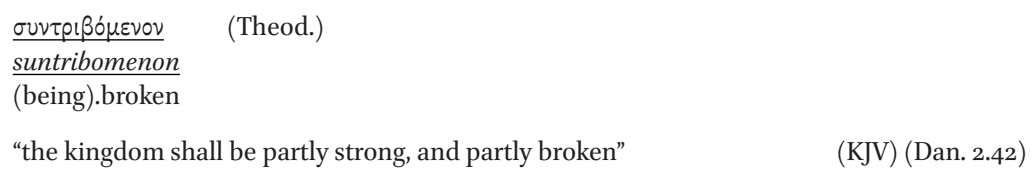

Here, the Hebrew/Aramaic original has a form of (hāa yāh) "be" with a passive

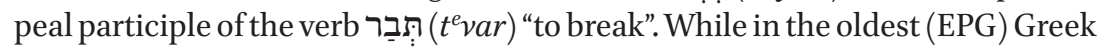
version, the Hebrew participle has been translated with a passive perfect par-

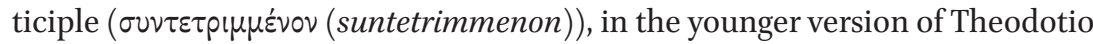
(generally dated to the second century $\mathrm{AD}$ ) we find the passive present partici-

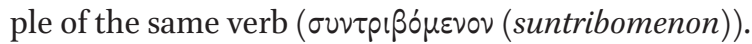

For the first time we also find an example where the construction with present participle has been extended to the anterior function. Consider (24), where the more regular perfect (or aorist participle) ${ }^{48}$ has been replaced by a passive present participle: ${ }^{49}$

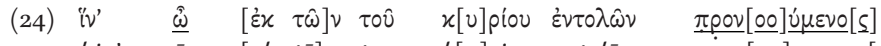

hin' $\underline{\bar{o}} \quad[e k$ tō $] n$ tou $k[u]$ riou entolōn pron $[0 o]$ umeno $[s]$

so.that I.am by the of.the master commands (being.provided.for/)

having.been.provided.for

"... so that I will have been provided for by the commands of the master"

(my translation/KB) (P.Giss.7, 2, 1. 21-22 (117 AD))

\subsubsection{2. है $\chi \omega$ with Active/Middle Aorist Participle (Anterior)}

We have seen that in EPG this construction only appears in the high register (i.c. the work of Dionysius of Halicarnassus), in imitation of the classical authors. The same is true for MPG, where we find the construction in the work of authors such as Plutarch and Cassius Dio. An example from the latter is given in (25):

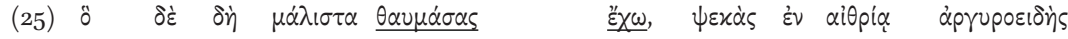
ho de dē malista thaumasas $\underline{\text { ekhō, }}$ psekas en aithriai arguroeidēs what PTC PTC most having.marveled.at I.have rain in clear.sky silvery

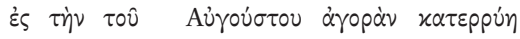

es tèn tou Augoustou agoran katerruē

to the of.the Augustus Forum ran.down

"but what I have marveled at most was this: a fine rain resembling silver descended from a clear sky up the Forum of Augustus"

(tr. Cary, slightly modified) (Cassius Dio, Hist. Rom. 75.4.7)

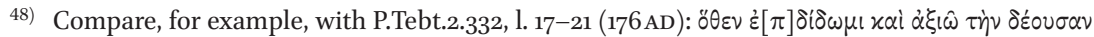

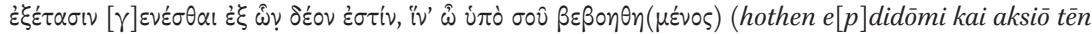
deousan eksetasin $[g]$ enesthai eks hōn deon estin, hin' ò hupo sou beboēthēe(menos)) "I accordingly present this petition and beg that due inquiry should be made of the proper persons, so that I will have been helped by you".

49) Cf. similarly P.Mil.Vogl.2.71, l. 26 (172-175 AD). 
It is interesting to note, however, that the construction also appears in a

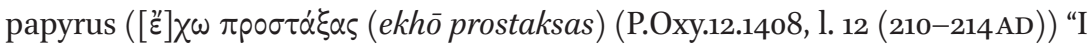
have ordered"). In another papyrus, we have an example of $\varepsilon^{\prime} \chi \omega(e k h \bar{o})$ with

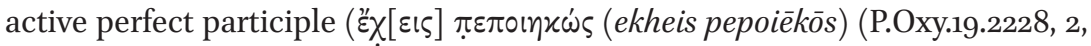
1. $40(285 \mathrm{AD}))$ "you have done"). In both cases, it is unclear what may have motivated the use of this high-register construction.

\subsubsection{3. है $\chi \omega$ with Active/Middle Aorist/Present Participle (Anterior)}

In her recent book, Moser (2009:219) compares examples of the kind found in (26) with the Classical construction of है $\chi \omega(e k h \bar{o})$ with aorist participle (cf. $\S 4.2 .5 .2)$. This is incorrect in so far as we are dealing here with an entirely novel, Post-classical formation (example (26) is the earliest instance I have found, from the second-century Testament ofJob).

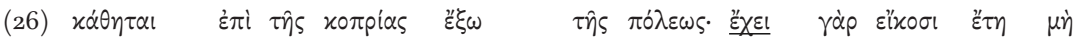

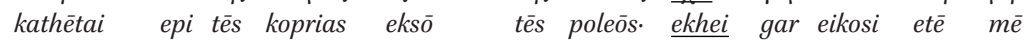
he.is.sitting on the dung-hill outside.of the city he.has for twenty years not

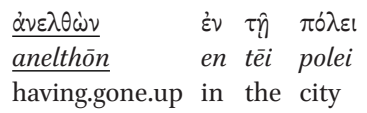

"he is sitting upon the dung-hill outside of the city; for he has not entered the city for twenty years"

(tr. James) (T. Job 28.8)

Previous scholarship (Tabachowitz 1943:24; Aerts 1965:162-164; Porter 1989:490491) has primarily focused on the fact that this construction can be 'reduced' to $\varepsilon^{\prime} \chi \omega(e k h \overline{)}$ taking a (temporal) object (rather than an accusative of time) and the participle fulfilling an 'explicative' function. In support of this claim, Aerts (1965:164) mentions examples such as $(27)^{50}$ and (28), which show that this explicative function could also be fulfilled by a temporal subclause or a locative adjunct:

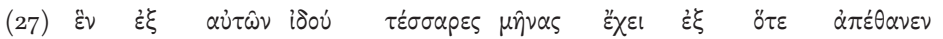
hen eks autōn idou tessares mēnas ekhei eks hote apethanen one from them behold four months it.has from when it.died "behold, one of them (the horses) died four months ago (lit. it has four months since it died)" (my translation/KB) (P.Oxy.16.1862, 1. 17-18 (ca. 624AD))

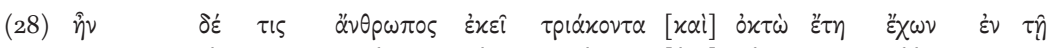
èn de tis anthrōpos ekei triakonta [kai] oktō etē ekhōn en tēi there.was PTC some man there thirty and eight years having in the

50) This example is of a later date, but I include it here because it is one of Aerts' better examples. 


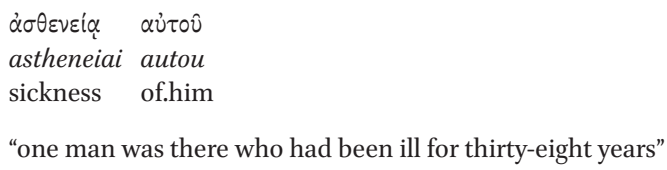

(NRS) (John 5.5)

Aerts (1965) and Porter (1989) both conclude that the construction in examples such as (26) cannot be considered 'truly' periphrastic. From a diachronic point of view, this is of lesser importance: that the component parts of a construction are (syntactically/functionally) still comparatively 'free' is typical for the early stages of the grammaticalization process. What is most important is that we are dealing here with an innovative construction, which is not to be considered related to the earlier mentioned $\varepsilon^{\prime} \chi \omega(e k h \bar{o})$ with aorist participle (used in imitation of the classical authors (see above)). This particular construction has come about through form-function reanalysis, i.e. through the structural ambiguity inherent in the construction of $\varepsilon^{\prime} \chi \omega(e k h \bar{o})$ accompanied by an accusative expressing time and a participle. Contrary to Aerts and others, I believe this ambiguity is also present in examples such as (28). As Liddell \& Scott (1968) indicate (see also Aerts 1965:165), already in Classical times, है $\chi \omega(e k h \bar{o})$ is well attested with prepositional/locative expressions (without a temporal object), where the verb is more or less equivalent to sipi (eimi) "I am, find myself" (e.g.

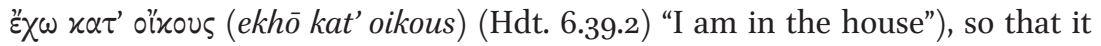

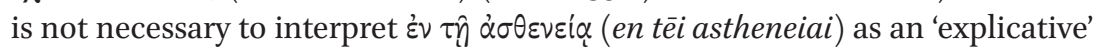
element.

It is worth noting that the construction of है $\chi \omega(e k h \bar{o})$ with a temporal complement/adjunct and a participle was not limited to the aorist participle: we also find examples with the present participle (see e.g. A. Thom. 43.19-20). Since both constructions (i.e. है $\chi \omega(e k h \bar{o})$ with aorist and present participle) are equally infrequent, I consider them to be independent innovations (rather than that one construction would be an extension of the other).

\subsubsection{4. $\varepsilon^{\prime} \chi \omega$ with Passive Aorist Participle (Resultative)}

As a fourth innovative expression, I can mention है $\chi \omega(e k h \bar{o})$ with passive aorist participle. What we observe here is similar to what we have observed for si $\mu$ i (eimi) with perfect and aorist participle: the functional merger of the synthetic perfect and aorist has also stimulated the interchangeability of the aorist and perfect participle in periphrastic constructions with है $\chi \omega(e k h \bar{o})$. Contrary to $\varepsilon i \mu i$ (eimi) with aorist participle, however, in MPG है $\chi \omega(e k h \bar{o})$ with (passive) aorist participle (with a resultative value) is very infrequent. In illustration, consider (29): 


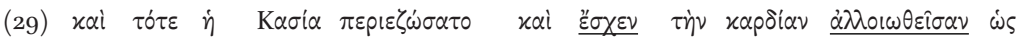

kai tote hē Kasia periezōsato kai eskhen tēn kardian alloiōtheisan hōs

and then the Kasia girdled.herself and had the heart transformed so.that

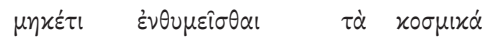

mēketi enthumeisthai ta kosmika

no.longer to.think.much.of the wordly.things

"then the other daughter, Kassia by name, put on the girdle, and she had her heart transformed, so that she no longer wished for worldly things"

(tr. James, slightly modified) (T.Job 49.1)

\subsection{Late Post-Classical Greek (IV-VIAD)}

4.3.1. Reconsidering the Lingueme Pool in LPG: Perfect Periphrases with $\varepsilon i \mu i^{\prime}$ and है $\chi \omega$

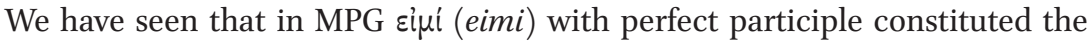
dominant perfect periphrasis for the expression of the resultative and anterior functions. At the same time, however, I have drawn attention to two innovative

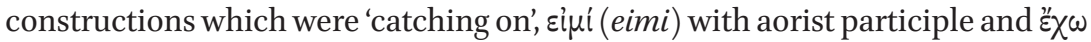
$(e k h \bar{o})$ with passive perfect participle. In what follows, we will have another look at the internal constitution of the 'lingueme pool' (cf. $§ 2.2$ ), to see how the competition between the three above-mentioned constructions is resolved in terms of elimination and functional specialization.

\subsubsection{1. sipi with Perfect Participle}

In LPG, हi $\mu i$ (eimi) with perfect participle is still the dominant perfect periphra-

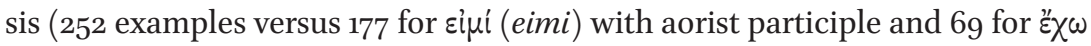
$(e k h \bar{o})$ with passive perfect participle). In absolute frequency, however, the construction is less often used than in the previous period, with an NRO of 2.3 per 10,000 words (versus 3 in MPG). This decrease is perhaps most clearly felt in the papyri, where I have found as little as 21 examples (versus 282 in EPG and 206 in MPG). Moreover, the trend towards functional specialization clearly continues. In table 8, I give an overview of the distribution of aspectual functions for Eiji (eimi) with perfect participle, with the data grouped on the basis of register (not including the papyri):

Table 8. Distribution of gi $\mu$ i with perfect participle in LPG (aspectual function).

\begin{tabular}{lllll} 
Period & Register & Total & Resultative & Anterior \\
\hline IV-VIAD & Middle & 130 & $104(80 \%)$ & $26(20 \%)$ \\
IV-VIAD & High & 101 & $55(54 \%)$ & $46(46 \%)$ \\
\hline
\end{tabular}

As this table shows, the construction of eipi (eimi) with perfect participle is predominantly used with a resultative function: $69 \%$ of all LPG examples (159/231) 
have this function. As in MPG, this trend is by far the most pronounced in the middle register, where as much as $80 \%$ of the examples of eiri (eimi) with perfect participle are used with a resultative function (versus $75 \%$ in MPG). An example is given in (30):

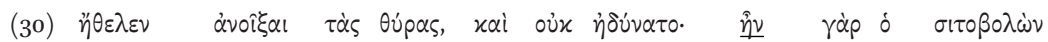
èthelen anoiksai tas thuras, kai ouk ēdunato. $\underline{\bar{e} n}$ gar ho sitobolōn he.wanted to.open the doors and not he.was.able it.was for the granary

\begin{tabular}{|c|c|}
\hline$\lambda \omega$ & $\pi \varepsilon \pi \lambda \eta \rho \omega \mu \varepsilon \dot{v}{ }^{\prime} S^{\prime}$ \\
\hline zolōs & peptērōmenos \\
\hline
\end{tabular}

"he wanted to open the doors, but he could not do so because the granary was completely filled with grain"

(tr. Wortley) (Jo. Mosch., Prat. 28.22-24)

While for the middle register the term 'functional specalization' is certainly warranted, this is much less the case for the high register: here, only $54 \%$ of the examples have the resultative function, which corresponds to what we have found in MPG for Plutarch and Cassius Dio. An example of eipi (eimi) with perfect participle with anterior function is given in (31):

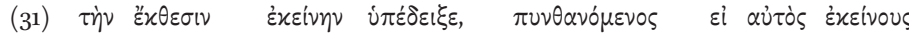

tēn ekthesin ekeinēn hupedeikse, punthanomenos ei autos eikeinous

the document this he.showed inquiring if self these

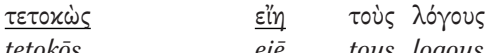

tetokōs $\quad \underline{e i \bar{e}}$ tous logous

having.brought.forth he.was the words

"he (Constantius) showed him the document in question and proceeded to enquire if he had brought forth the words in it" (tr. Schaff, modified) (Thdt., H.E. 160.20-21)

Another trend which continues in the LPG period is the restricted contexts of use of the construction (with regard to mood, tense and voice), when compared to EPG and especially CG. Table 9 shows the distribution of the construction in the middle and high register with regard to mood:

Table 9. Distribution of $\varepsilon i \mu i$ with perfect participle (mood).

\begin{tabular}{lllllllll} 
Period & Register & Total & IMP & IND & INF & OPT & PART & SUBJ \\
\hline IV-VIAD & Middle & 130 & $2(2 \%)$ & $104(80 \%)$ & $7(5 \%)$ & $7(5 \%)$ & $7(5 \%)$ & $3(3 \%)$ \\
IV-VIAD & High & 101 & o & $69(68 \%)$ & $8(8 \%)$ & $10(10 \%)$ & $12(12 \%)$ & $2(2 \%)$ \\
\hline
\end{tabular}

Key: 'IMP' = imperative; 'IND' = indicative; 'INF' = infinitive; 'OPT' = optative; 'PART' = participle; 'SUBJ' = subjunctive.

Especially in the middle register, eijui (eimi) with perfect participle is predominantly used in the indicative mood ( $80 \%$ of the examples), with only few examples in the other moods. As for tense, the future perfect rarely occurs, with only 
five instances in the literary texts. Moreover, in three out of five examples, we are dealing with a quote from the New Testament (Mt. 16.19). As far as voice is concerned, $78 \%(181 / 231)$ of the examples occur in the passive voice. There is no notable register difference: both in the middle and the high register the passive is clearly favored (with respectively 102/130 (78.4\%) and 79/101 (78.2\%)).

As for the papyri, I have already mentioned that the construction occurs rather infrequently (with 21 examples). It is noteworthy that statistically the tendencies which I have described above are less pronounced in these documents (62\% of the examples have the resultative function, $57 \%$ occur in the indicative mood), ${ }^{51}$ which may be (partly) due to the low total number of examples. The use of eipi (eimi) with perfect participle in formulaic expressions is now limited to a single instance (P.Stras.6.56o, l. 11 (324AD)).

\subsubsection{2. eipi with Aorist Participle}

In LPG, the construction of eipi (eimi) with aorist participle takes off: while in

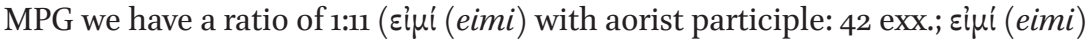
with perfect participle: 453 exx.), in LPG the ratio shifts quite dramatically to

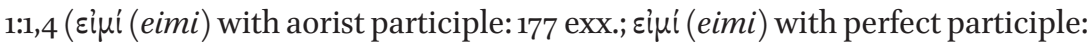
252 exx.). The rise of $\varepsilon i \mu i$ (eimi) with aorist participle should be situated in the (low and) middle register: the NRO for the high register is 0.5 per 10,000 words (28 examples), while that for the middle register is 2.4 per 10,000 words (135 examples). In table 10, I have grouped the middle-register texts in which the construction occurs most frequently:

Table 10. Frequency of occurrence of Eipi with aorist participle in LPG.

\begin{tabular}{lllll} 
Period & Text & Author & $\begin{array}{l}\text { NRO } \\
(/ \mathbf{1 0 o o o})\end{array}$ \\
\hline IVAD & Life of Anthony & Athanasius & 6 & 3.1 \\
VAD & Acts of Barnabas & & 2 & $(9.0)$ \\
VAD & Life of Alexander & & 4 & 4.3 \\
VAD & Life of St. Hypatius & Callinicus & 7 & 3.2 \\
VAD & Life of Porphyrius bishop of Gaza & Mark the Deacon & 5 & 3.1 \\
VAD & Life of St. Syncletica & & 4 & 2.7 \\
VIAD & Life of Abramius & Cyrillus of Scythopolis & 2 & $(18.0)$ \\
VIAD & Chronography & John Malalas & 56 & 6.1 \\
VIAD & Life of Cyriacus & Cyrillus of Scythopolis & 1 & 2.6 \\
VI-VIIAD & Spritual Meadow & John Moschus & 21 & 4.1 \\
\hline
\end{tabular}

51) Surprisingly, we still find three examples with the periphrastic construction in the subjunctive $\operatorname{mood}($ P.Stras.6.56o, l. 12 (324AD); P.Ammon.1.13, l. 66 (348 AD); P.Oxy.16.1870, 1. 6 (VAD)) and two in the optative mood (P.Oxy.10.1265, l. 13 (336 AD); P.Muench.1.6, 1. 38 (583AD)). As noted above, only one of these instances is formulaic. 
The data from this table show that the construction was most frequently used in fifth- and sixth-century Greek, especially in the work of John Malalas and John Moschus.

We must look upon the spread of eipi (eimi) with aorist participle in the middle register in terms of language-internal ecology, connecting it with the

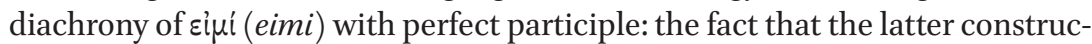
tion became functionally specialized towards the expression of the resultative function in the middle register (already in MPG), must have favored the devel-

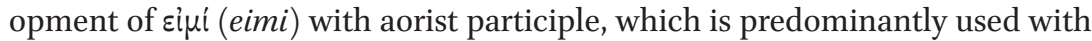
an anterior function $(83 \%(=112 / 135)) .{ }^{52}$ In the high register, on the other hand, Eini (eimi) with perfect participle remained the dominant perfect periphrasis for both the resultative and the anterior function, thus blocking the spread of $\varepsilon$ -

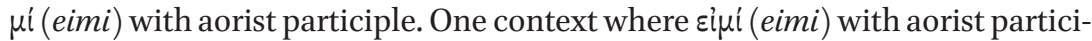
ple does seem to have gained some ground in the high register is the active anterior perfect (cf. my earlier observations with regard to voice): out of 28 examples in the high register only 5 are passive $(=18 \%)$, while in the middle register 37 out of 135 are passive $(=27 \%)$.

As has been observed by a number of scholars (Björck 1940:74; Mihevc 1959:

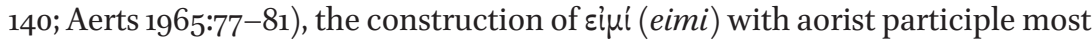
frequently occurs with si $\mu^{\prime}($ eimi) in the imperfect tense $(159 / 177=90 \%(!))$. In many of these examples, a (explanatory) particle immediately follows the finite

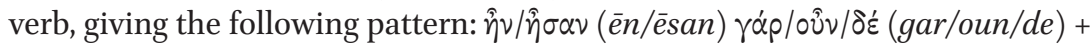
aorist participle. To take the example of John Malalas, this template accounts for $74 \%(=32 / 43)$ of the examples (out of 43 main clause anteriors, 27 occur with ráp (gar), 1 with ơ̂v (oun) and 4 with $\delta \dot{\varepsilon}($ de)). In John Moschus, this percentage is even higher: here, $82 \%(9 / 11)$ follow this pattern (11 examples of main clause anteriors, 4 with $\gamma \alpha \dot{\alpha}$ (gar) and 5 with $\delta \dot{\varepsilon}(d e))$. An example is given in (32):

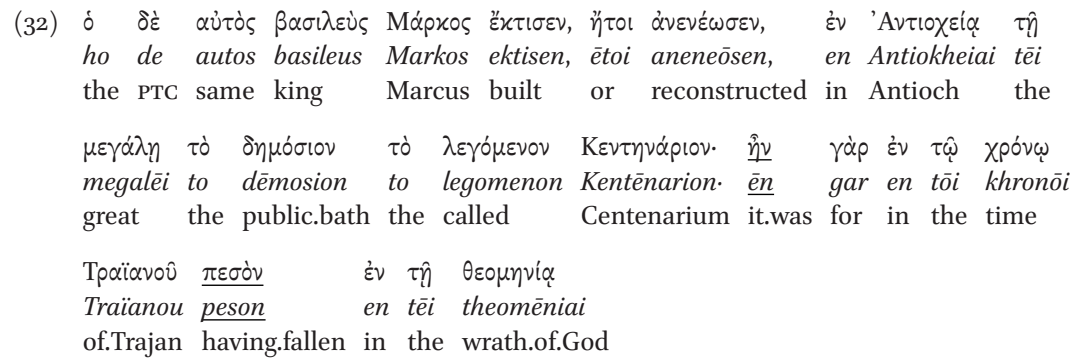

\footnotetext{
52) I should stress, however, that the construction of eipi (eimi) with aorist participle is predominantly used as an anterior, not exclusively. For some examples where this would not be the case, see e.g. Ath., V. Ant. 6.19; Jo. Mal., Chron. 410.6-8; Pall., H. Laus. 44.4; V. Pach. 114.2; V. Sym. Styl. J. 166.8; V. Syncl. 90, 147, 1146.
} 
"the emperor Marcus built, or reconstructed, in Antioch the Great the public bath known as the Centenarium. For it had collapsed in the time of Trajan during the wrath of God"

(tr. Jeffreys et al.) (Jo. Mal., Chron. 282.9-10)

Björck (1940), Mihevc (1959) and Aerts (1965) explain the predominance of the imperfect tense on paradigmatic grounds: they characterize eipi (eimi) with aorist participle as a 'pluperfect periphrasis' replacing the synthetic pluperfect (Jannaris 1897:441 indicates that the loss of the synthetic tense was by and large effected in the low/middle register in LPG). While the loss of the synthetic pluperfect must indeed be considered an important ecological factor, this suggestion leaves a number of questions unanswered: (a) why would the loss of the synthetic pluperfect affect specifically giju (eimi) with aorist participle (see

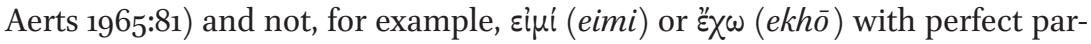
ticiple? (b) if we take it that sixi (eimi) with aorist participle did indeed function as a substitute for the synthetic pluperfect, why then does it almost exclusively have an anterior function (see above), whereas the synthetic pluperfect could function both as a resultative and an anterior? Moreover, it should be noted that examples of ei if (eimi) with aorist participle with the auxiliary in the present tense are not entirely absent, ${ }^{53}$ contrary to what some would have us believe.

In my view, too little attention has been paid to the (diachronic) interrelationship of हiji (eimi) with perfect and aorist participle. As I have outlined above, the competition between these two constructions resulted in a functional division: ijui (eimi) with perfect participle became the dominant periphrasis for the resultative aspectual function and si $\mu i$ (eimi) with aorist participle for the anterior function. As such, both constructions 'substitute' for the old synthetic pluperfect, and will have benefitted more or less equally from the demise of the synthetic pluperfect (which could be used with both functions). As for eini (eimi) with aorist participle, 90\% imperfect indicatives is a remarkably high number, but we should not forget that in Post-classical (especially Late Post-classical) Greek, the indicative had become the dominant mood (Mirambel 1966:176). Moreover, if we look at the use of gini (eimi) with perfect participle as an anterior perfect (from Archaic/Classical to Middle Post-classical Greek), as shown in Table 11 (based on literary texts; the data for Archaic/Classical Greek are taken from Bentein 2012), we find that this periphrasis too was predominantly used with sipi (eimi) in the imperfect tense. However, as siji (eimi) with aorist participle is almost exclusively used as an anterior perfect (see above), the occurrence of imperfects is much more noticeable.

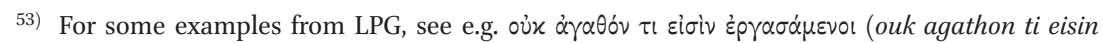

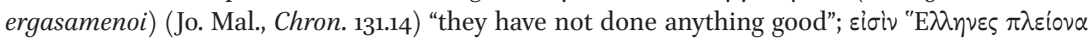

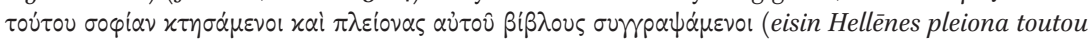


Table 11. Distribution of anterior sixi with perfect participle from A/CG to MPG (indicative mood and imperfect tense).

\begin{tabular}{llll} 
& A/CG & EPG & MPG \\
\hline Indicative forms & 282 & 74 & 68 \\
Imperfect forms & $147 / 282(52 \%)$ & $60 / 74(81 \%)$ & $56 / 68(82 \%)$ \\
\hline
\end{tabular}

The prevalence of the imperfect tense with both sipi (eimi) with perfect participle and siji (eimi) with aorist participle (when used with an anterior aspectual function) can be explained as follows: since the anterior perfect typically has an explanatory or relational function, providing background information to the main events, and since most of the corpus consists of narrative texts (which are mostly about past events), it seems natural that the additional information provided by the periphrastic anterior also lies in the past (to be more specific, one step further in the past). This also explains why the number of imperfect forms is less pronounced in Archaic and Classical Greek: for these periods, I have also taken into account non-narrative texts (Bentein 2012).

\subsubsection{3. "ै $\chi \omega$ with Passive Perfect Participle}

The third construction which must be mentioned here is $\varepsilon^{\prime} \chi \omega(e k h \bar{o})$ with passive perfect participle. Similarly to what was noted for eipi (eimi) with aorist participle, the rate of occurrence vis-à-vis the dominant perfect periphrasis, $\varepsilon \grave{\text { l- }}$

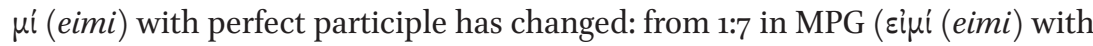
perfect participle: 453 exx.; $\varepsilon^{\prime} \chi \omega(e k h \bar{~})$ with passive perfect participle: 65 exx.) to

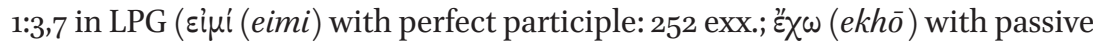
perfect participle: 69 exx.). However, this shift is primarily due to the decline

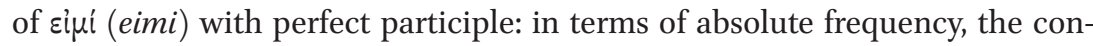
struction of है $\chi \omega(e k h \bar{o})$ with passive perfect participle remains more or less stable compared to the previous period (with a small decrease in frequency from NRO 0.7 per 10,000 words in MPG to 0.6 per 10,000 words in LPG (excluding the papyri)).

Past scholarship has not been very clear about the status of this construction. As we have already seen (cf. $§ 4.2 .4)$, Horrocks (2010:131-132) writes about है $\chi \omega(e k h \bar{o})$ with passive perfect participle ('in an active, transitive sense') that "with the advent of a more stringent Atticist approach in the 2nd century AD, it quickly disappeared even from stylistically middle-brow compositions", only to reappear in Late Byzantine Greek. Aerts (1965:161-164) similarly does not cite any examples from LPG. According to Jannaris (1897:498), on the other hand, by Byzantine times (i.e. from the seventh century onwards) and possibly even earlier (i.e. in LPG), the perfect, pluperfect and future perfect were formed (to 


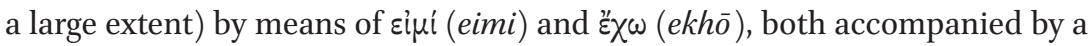
passive perfect participle (the former being used as a resultative perfect and the latter as an anterior).

In LPG, the division of perfect functions between the constructions of zipi (eimi) with perfect participle (resultative function) and हi $\mu$ i (eimi) with aorist participle (anterior function) does not leave much room for the development of $\varepsilon^{\prime} \chi \omega(e k h \bar{o})$ with passive perfect participle. This is not to deny, however, that the construction was used in this period of the language (contrast with Horrocks). As in the previous periods, it could be used with both a resultative and an anterior function, though the latter only by pragmatic inference (the perfect participle still being in concord with the accusative object). In my corpus, the construction is most often used to indicate the (generally very bad) physical condition of the subject, as in (33) (note the co-ordination of the perfect participle with the adjective $\delta v \sigma \omega \delta \dot{\varepsilon} \sigma \tau \alpha \tau \nu):{ }^{54}$

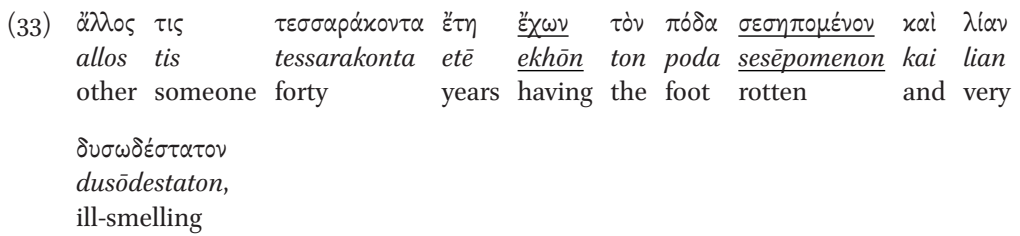

"another person had his foot rotten for forty years and very ill-smelling"

(my translation/KB) (V. Sym. Styl.Jun. 153.1-2)

As discussed above, in LPG the resultative function is the core domain of $\varepsilon i \mu i$ (eimi) with perfect participle. As such, both constructions are used in very similar contexts: compare (33) to (34), from the same vita:

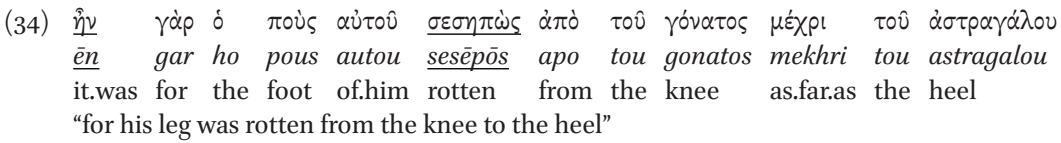

(my translation/KB) (V. Sym. Styl.Jun. 152.2-3)

The semantic difference between these two cases would be that in (33) focus lies on the condition of the sick person, while in (34) the bad foot is specifically focused upon.

In a minority of the examples, है $\chi \omega(e k h \bar{o})$ with perfect participle (possibly) has an anterior function (by pragmatic inference) $(19 / 69=28 \%)$. In (35),

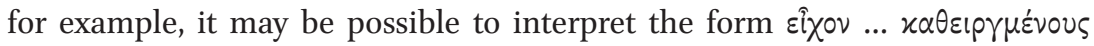

\footnotetext{
54) It will come as no surprise that this type of construction is particularly often found in the lives of the saints, where the condition of the saint is at stake, or the condition of the person who is in need of healing.
} 
(eikhon ... katheirgmenous) as an anterior ("those whom they had imprisoned on account of ..."):

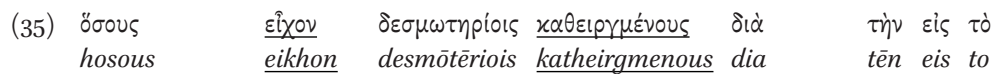
as.many.as.Acc they.had in.prisons shut.in because.of the to the

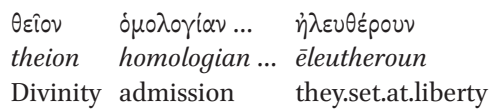

"those whom they had imprisoned on account of their confession of the Deity, they set at liberty"

(tr. McGiffert) (Eus., H.E. 9.1.7)

However, the placement of the locative adjunct $\delta \varepsilon \sigma \mu \omega \tau \eta$ piors (desmōtēriois) in between the finite verb and the perfect participle may indicate that a resultative interpretation is more plausible ("those whom they had in the prisons, confined on account of ..."). In any case, we are still far away from है $\chi \omega(e k h \bar{o})$ with perfect passive 'taking over' the anterior perfect function.

That $\varepsilon^{\prime} \chi \omega(e k h \bar{o})$ with passive perfect participle tends towards the resultative function is also clear in the papyri. I have found six examples of the construc-

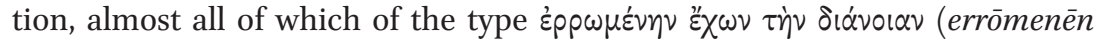

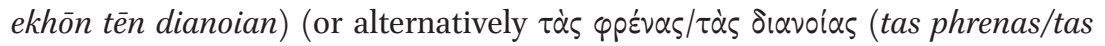
dianoias)) "having a sane mind (lit. the mind sane)". ${ }^{55}$

\subsubsection{Catching On: $\varepsilon_{\chi} \chi \omega$ with Active/Middle Aorist/Present Participle (Perfect} of Persistence)

One HAVE-construction which does seem to be catching on is that of $\varepsilon^{\prime} \chi \omega(e k h \bar{o})$ with present/aorist participle accompanied by a temporal adjunct (cf. $§ 4.2 .5 \cdot 3$ for the origins of the construction). This construction is always used with one specific anterior function, which is rather infrequently expressed by the other periphrases mentioned under $\S$ 4.3.1 (so that we can hardly speak of any competition). ${ }^{56}$ In the literature, this subfunction is called that of the 'perfect of persistence' (Bentein 2012: 180), indicating that an event has begun in the past and is still ongoing at the time of reference, as in "John has been coughing since Wednesday". In illustration, consider example (36), where the ego summarizes the tasks he has been fulfilling for the last sixty years:

\footnotetext{
55) See Stud.Pal.1.1, l. 2-4 (480 AD); P.Muench.1.16, 1. 8 (VAD); P.Muench.1.8, 1. 8 (540 AD); P.Cair. Masp.3.67312, l. 12-13 (567AD); P.Lond.5.1727, l. 18 (583-584AD); P.Oxy.20.2283, l. 8 (586 AD).

56) As noted by Smyth (1984[1920]:422-424), Ancient Greek could also use the synthetic present/ imperfect to express this subfunction (though not exclusively, contra Haverling 2009:355), as in $\pi \dot{\alpha} \lambda \alpha \iota$ Ө $\alpha \mu_{\alpha} \dot{\zeta} \zeta \omega$ (palai thaumazō) "I have been wondering since long".
} 


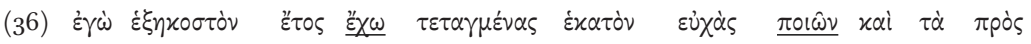
egō heksēkoston etos ekhō tetagmenas hekaton eukhas poiōn kai ta pros I sixtieth year have fixed hundred prayers doing and the for

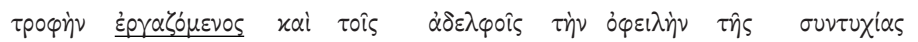
trophēn ergazomenos kai tois adelphois tēn opheilēn tēs suntukhias food doing and for.the brothers the need of.the meeting

$\dot{\alpha} \pi 0 \delta 1 \delta 0 u ́ s$

apodidous

conceding

"for sixty years I have been reciting (every day) one hundred prayers, I have been taking care of the food, and I have satisfied the need to concede the (other) brothers private talks"

(tr. Bartelink, slightly modified (originally in Italian)) (Pall., H. Laus. 20.3)

In this example, we see that $\varepsilon^{\prime} \chi \omega(e k h \bar{o})$ is used three times with the present participle. However, as we have already observed for MPG, the aorist participle could also be used (this concerns a minority of the examples $(9 / 28=32 \%)$ ). Interesting in this context is (37), where we find the two types of participle coordinated:

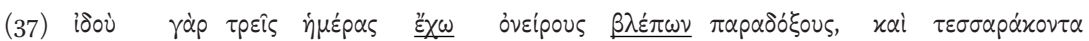
idou gar treis hēmeras ekhō oneirous blepōn paradoksous, kai tessarakonta behold for three days I.have dreams seeing incredible and forty

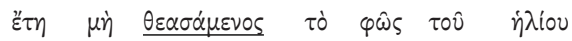

etē mè theasamenos to phōs tou hèliou

years not having.seen the light of.the sun

"behold for I have been seeing incredible dreams for three days, and for forty years I have not seen the light of the sun"

(my translation/KB) (A. Phil. (Xen. 32) 12.2)

The most noteworthy difference between the use of the present and aorist participle in this example seems to be that only the latter is accompanied by the negation $\mu \eta^{\prime}(m \bar{e})$. Further analysis shows that the negation in fact occurs in almost half of the examples (4/9) with the aorist participle (also note that the negation already occurs in the example cited from MPG $(=(26))$. I would argue that there is a semantic difference between examples with versus examples without the negation, favoring the use of the present versus the aorist participle: when the negation is used, we are dealing with a non-prototypical use of the perfect of persistence, as the event denoted by the participle in fact has not occurred during a certain time period including the present (or to be more precise the reference point). When the negation is not used, the continuation of the event denoted by the participle is stressed. The latter context seems to be much better suited to the present rather than the aorist participle. ${ }^{57}$

57) It is hard to make any generalizations, though: the present participle can also be accompanied 
To close this section, it should be noted that the use of this construction is not only semantically but also morphologically and pragmatically (i.e. registerially) restricted. The construction is mainly used with $\varepsilon^{\prime} \chi \omega(e k h \bar{o})$ in the first/third

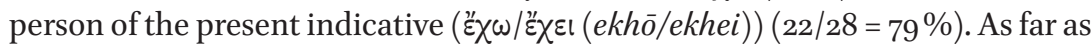
register is concerned, the construction is almost exclusively used in the middle register. While I have found no instances in texts from the high register, I have come across one instance in the papyri, example (38):

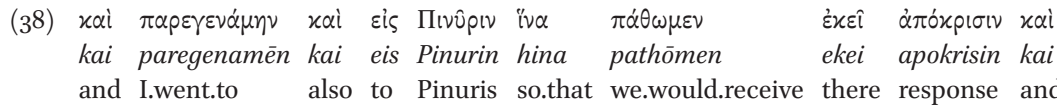

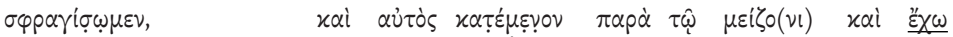

sphragisōmen, kai autos katemenon para tōi meizo(ni) kai ekhō

we.would.close.with.a.seal and self I.remained with the headman and I.have

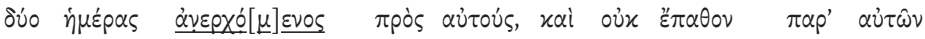

duo hèmeras anerkho[m]enos pros autous, kai ouk epathon par' autōn

two days going.up to them and not I.received from them

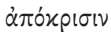

apokrisin

response

"I went also to Pinuris in order that I might get a response there and might affix the seal, and I remained myself with the headman and have been two days travelling up to them, and got no response from them"

(tr. Grenfell et al.) (P.Oxy.16.1855, l. 8-10 (VI/VIIAD))

\subsubsection{First Order Variation: Alternative Periphrastic Perfect Constructions}

For LPG I can again mention a number of constructions which fall under the heading of 'first-order variation'. This concerns the following constructions with

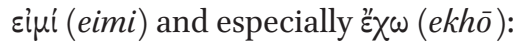

\subsubsection{Eimi with (Passive) Present Participle (Resultative/Anterior)}

We have encountered the construction of $\varepsilon i \mu i$ (eimi) with (passive) present participle sporadically in EPG and MPG, mostly with a resultative function. An example from LPG is given in (39):

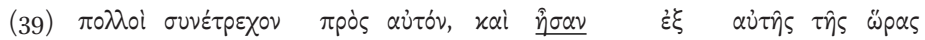

polloi sunetrekhon pros auton, kai $\underline{\bar{e} s a n}$ eks autēs tēs hōras

many ran.together to him and they.were from this the hour

by the negation (though only exceptionally) (see e.g. Pall., H. Laus. 38.13), and the aorist participle without it (see e.g. Hist. Mon. Aeg. 14.29), expressing an ongoing event. 


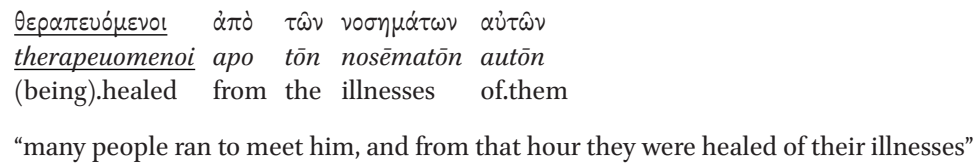
(my translation/KB) (A. Phil. (Xen. 32) 4.1)

While the resultative character of the present participle $\theta \varepsilon p \alpha \pi \varepsilon v o$ $\mu \varepsilon v o$ เ may be

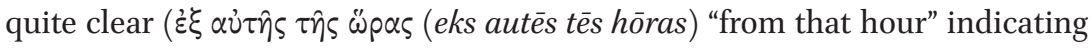
that a state obtains starting from a certain point in time), in other examples this is much less the case. Consider example (40): does the present participle

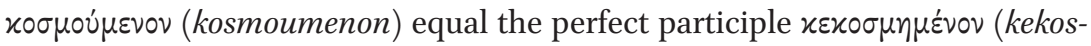
mèmenon), or does the choice for the present participle indicate some kind of special emphasis? In any case, it cannot be denied that there is an approximation of the two types of participle in examples such as these. ${ }^{58}$

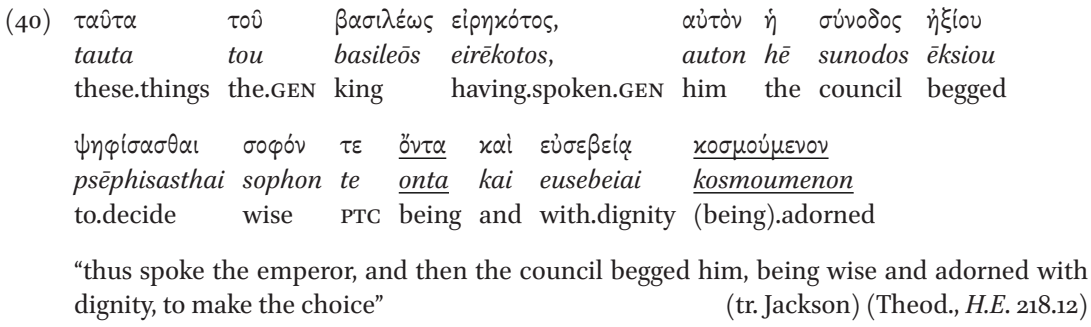

As in MPG, we also find the construction with an anterior function. An example from the papyri is given in (41):

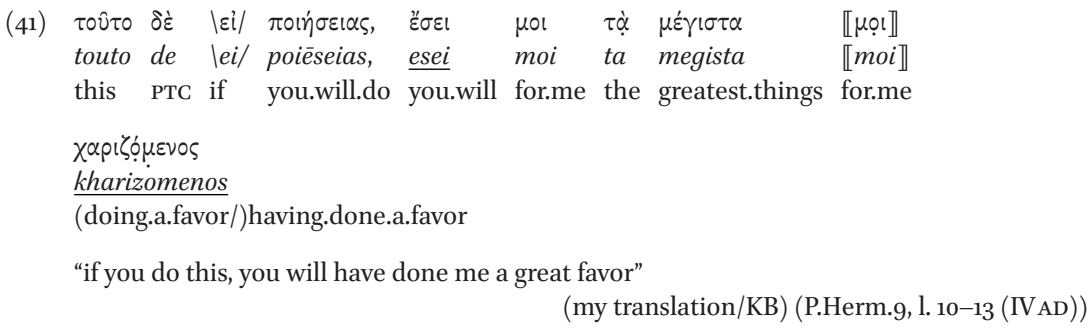

Formulaic expressions of this type (which abound in MPG and especially EPG) have become very rare in LPG, even with the perfect and aorist participle.

\subsubsection{2. है $\chi \omega$ with Active/Middle Aorist (Perfect) Participle (Anterior)}

We have already come across this construction in both of the above discussed stages of the Greek language. As in these periods, the construction is mainly

58) Cf. similarly Jo. Mal., Chron. 257.23; V. Sym. Styl. J. 193.3-4, 234.11-12; V. Syncl. 174-175. 
limited to the high register (i.c. historiographical works). As an illustration, consider example (42), from Sozomenus' Ecclesiastical History:

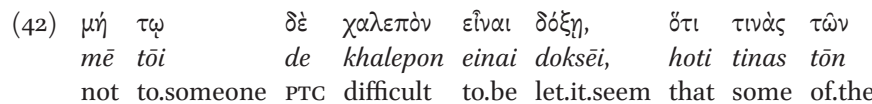

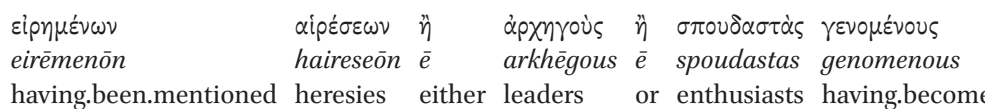

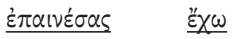

epainesas $\underline{e k h o ̄}$

having.praised I.have

"let it not be accounted strange, if I have bestowed commendations upon the leaders or enthusiasts of the above-mentioned heresies" ～（tr. Hartranft) (Soz., H.E. 3.15.10)

As in MPG, an example of the construction can also be found in the papyri ( $\varepsilon \chi \chi \omega$ $\pi \varepsilon \dot{\varepsilon} \psi \alpha \alpha_{\varsigma}$ (ekhō pempsas) (P.Stras.1.35, 1. 5-6 (IV/VAD)) “I have sent"). In Zosimus' New History there is one instance of $\varepsilon^{\prime} \chi \omega(e k h \bar{o})$ with the active perfect participle

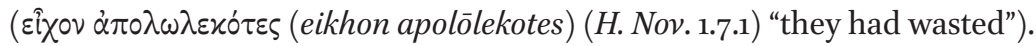

\subsubsection{3. "ै $\chi \omega$ with Passive Aorist Participle (Resultative)}

It is important to distinguish $\varepsilon^{\prime} \chi \omega(e k h \bar{o})$ with passive aorist participle from the construction with active/middle aorist/perfect participle mentioned under $\S 4.3 .3 .2$. Rather than being a conscious imitation, we are dealing here with an innovation which has come about through intraference, i.c. the extension of the passive perfect participle to the passive aorist participle. In illustration, consider example (43), with the verb $\sigma \dot{\eta} \pi \omega(s \bar{e} p \bar{o})$ "I make rotten" (compare with $(33)):^{59}$

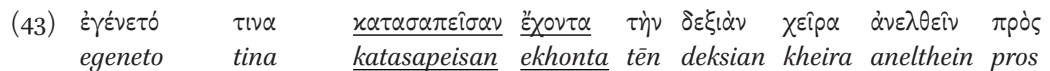

it.happened someone rotten having the right hand to.go.up to

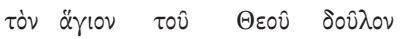

ton hagion tou Theou doulon

the holy of.the Lord servant

"it happened that someone who had a rotten right hand (lit. who had his right hand rotten) went to the holy servant of God"

(my translation/KB) (V. Sym. Styl. Jun. 234.1-2)

\subsubsection{4. "ैं $\chi \omega$ with Passive Present Participle (Resultative)}

One innovative construction which we have not encountered in any of the previous periods is that of $\varepsilon^{\prime} \chi \omega(e k h \bar{o})$ with passive present participle (with a

59) For two additional examples, see Ath., V. Ant. 48.13; V. Syncl. 1038. 
resultative function). This innovation is hardly unexpected: following the extension of eipi (eimi) with passive perfect participle to the aorist and present participle, the construction of $\varepsilon^{\prime} \chi \omega(e k h \bar{o})$ with passive perfect participle is extended to the passive aorist and finally present participle as well. In his discussion of periphrasis in John Malalas, Wolf (1912:56) mentions our example (44),

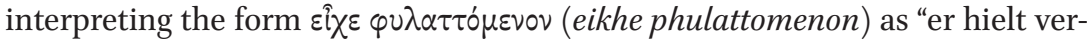
wahrt, habebat (tenebat) asservatum":

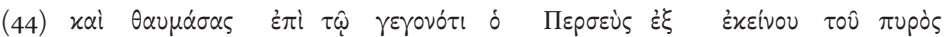

kai thaumasas epi tōi gegonoti ho Perseus eks ekeinou tou puros

and amazed by the event the Perseus from this the fire

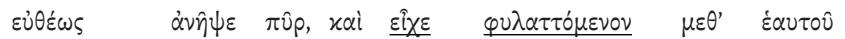

eutheōs anēpse pur, kai eikhe phulattomenon meth' heautou

immediately he.lit fire and he.had (being).guarded with himself

"amazed by this event, Perseus immediately lit a fire from that fire and he kept it with him under protection"

(tr. Jeffreys et al.) (Jo. Mal., Chron. 38.8)

\subsection{Early Byzantine Greek (VII-VIIIAD)}

The last period which I consider in the context of this article is that of Early Byzantine Greek. Before starting my discussion, it is worth recalling an important language-internal ecological factor, that is, the decline of the participle. This gradual process ${ }^{60}$ particularly affected the active present/perfect/aorist participle, next to the passive aorist participle, which were being reduced to indeclinable forms, functioning adverbially (Mirambel 1961:50 cites some examples from the second century AD; see also Jannaris 1897:207 and Dieterich 1898:

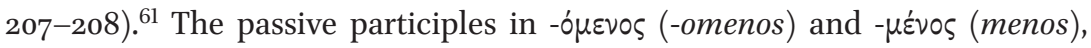
on the other hand, remained in use throughout. Unsurprisingly, several scholars have mentioned the profound effect of this development on the use of periphrastic constructions. Horrocks (2010:131), for example, writes that "but as the use of the inflected participles of the 3 rd declension ... began to whither away ... the periphrasis with the perfect passive participle ... emerged as the

60) According to the standard account, these changes in the participial system are to be attributed to the morphological complexity of the endings of the active (and passive aorist) participle, or more generally of the third declension paradigm, next to functional motivations such as the avoidance of ambiguity and the preference for analytic expression (either by parataxis or subordination) (Jannaris 1897:504-506; Dieterich 1898:206; Horrocks 2010:131-132). For an alternative view, see Manolessou (2005).

61) Eventually (i.e. between the tenth and the thirteenth centuries, see Mirambel 1966:186), this led to the formation of a gerund in $-o v \tau \alpha(\varsigma)(-o n t a(s))$, with syncretization of the present and aorist participle, and the elimination of the passive aorist and active perfect participle (which were replaced by novel expressions, see Mirambel 1961:68). 


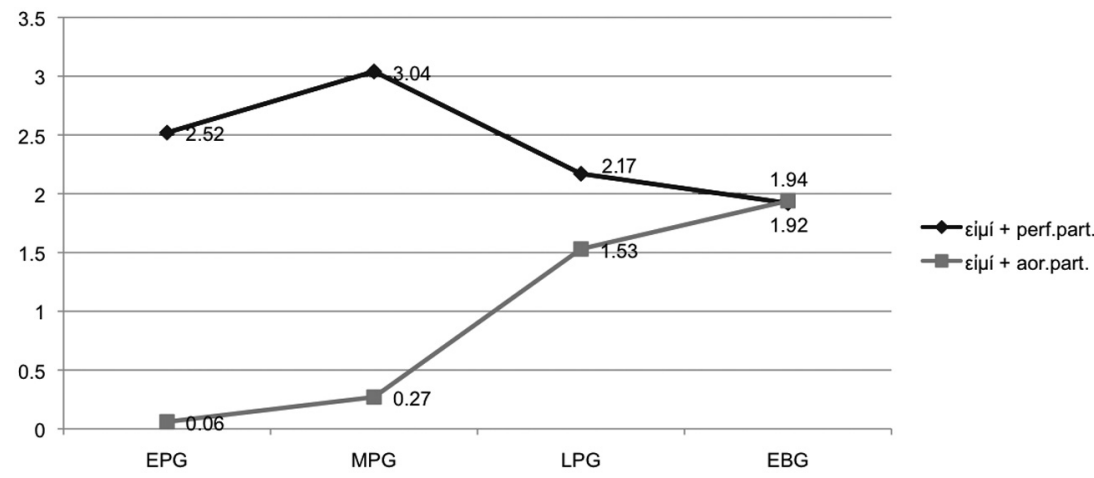

Figure 2. Frequency of occurrence of sifí with perfect and aorist participle (from EPG to EBG).

major survivor in popular Greek of the medieval period" (cf. also Mirambel 1966:180-183; Browning 1969:69).

\subsubsection{Continuing the LPG Trend: Dominance of $\varepsilon i \mu i$ with Aorist Participle}

In the previous parts of this article, I have discussed the gradual rise of eipi (eimi) with aorist participle, which, having started out as an innovation in EPG, gained firm ground in MPG and LPG, where it mainly functioned with the value of an anterior perfect. In EBG we witness a shift in dominance: for the first time in the history of the language, the construction of gini (eimi) with aorist participle is more often attested than that of eifi (eimi) with perfect participle (141 examples with aorist participle versus 133 examples with perfect participle (including the papyri)). The overall development of the two constructions is shown in Figure 2: here we see that both constructions have reached an NRO of about 2 per 10,000 words, which in the case of gipi (eimi) with perfect participle is the outcome of a gradual decrease in frequency, while for ei $\mu i$ (eimi) with aorist participle it is the result of a gradual increase in frequency. In both cases, the most crucial period is the transition from MPG to LPG.

To a very large extent, the situation in EBG constitutes a continuation of the tendencies observed in the previous periods. Semantically, for example,

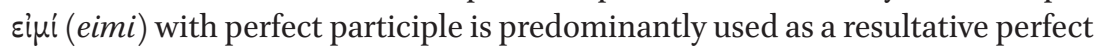

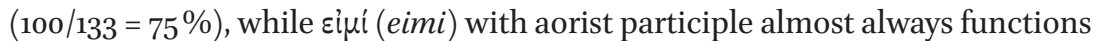
as an anterior perfect $(123 / 141=87 \%) \cdot{ }^{62}$ An example of each construction is

62) As in the previous periods, however, there are a number of examples where the construction has a resultative or even progressive value. See e.g. Georg. S., V. Theod. S. 72.32-33, 81.2-3, 106.14-15; Leont. N., V.Jo. Eleem. 343.10-11; Thphn., Chron. 334.6, 481.30-31. 
given in (45) and (46) (note the occurrence of the $\hat{\eta} \nu$ yáp (ēn gar)-pattern in (46) (cf. $§ 4.3 \cdot 1.2))$ :

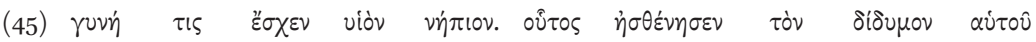
gunē tis eskhen huion nēpion. houtos èsthenēsen ton didumon hautou woman some had son infant he became.sick in.the testicle of.himself

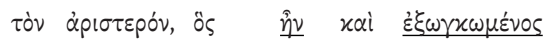

ton aristeron, hos $\underline{\bar{e} n}$ kai eksōnkōmenos

the left which was also swollen

"a certain woman had an infant son. This son became diseased in his left testicle, which was also swollen"

(tr. Crisafulli) (xlv mir. Artem. 71.9)

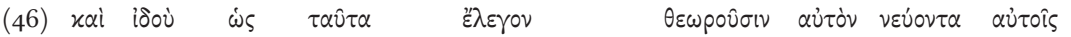

kai idou hōs tauta theōrousin auton neuonta autois and behold when these.things they.were.saying they.see him nodding to.them

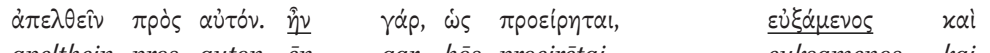
apelthein pros auton. $\underline{\bar{e} n}$ gar, hōs proeirētai, euksamenos kai to.come to him he.was for as it.has.been.said.before having.prayed and

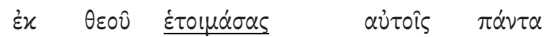

ek theou hetoimasas autois panta

from God having.prepared for.them all.things

"and behold, when they said this, they saw him motioning them to come toward him. For he had prayed, as I said, and with God's help he had prepared everything"

(tr. Krueger) (Leont. N., V. Sym. 98.1-2)

Morphologically, the construction with perfect participle is mainly used in the indicative mood $(99 / 133=74 \%$ ) (with no examples in the subjunctive mood and only a few in the optative), in the passive voice $(91 / 133=68 \%)$, and in the present or imperfect tense of the indicative mood $(86 / 99$ indicatives $=87 \%$ ). The construction with aorist participle, on the other hand, is again mainly limited to the indicative imperfect $(130 / 141=92 \%)$ and is by and large formed with the active or middle participle $(106 / 141=75 \%)$.

The most noticeable findings are perhaps situated in the pragmatic (registerial) domain. Consider Table 12, where I have represented the use of both constructions in the middle and high register:

Table 12. Distribution of gi $\mu$ í with perfect and aorist participle in EBG (aspectual function).

\begin{tabular}{|c|c|c|c|c|c|}
\hline Construction & Register & Total & $\begin{array}{l}\text { NRO } \\
(/ 10000)\end{array}$ & Resultative & Anterior \\
\hline$\varepsilon i \mu i^{\prime}+$ perf. part. & Middle & $119 / 133(=89 \%)$ & 2.3 & $90 / 119(76 \%)$ & $29 / 119(24 \%)$ \\
\hline 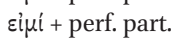 & High & $14 / 133(=11 \%)$ & 0.8 & $10 / 14(=71 \%)$ & $4 / 14(=29 \%)$ \\
\hline 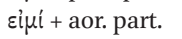 & Middle & $123 / 135(91 \%)$ & 2.4 & $17 / 123(=14 \%)$ & $106 / 123(=86 \%)$ \\
\hline 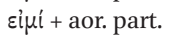 & High & $12 / 135(9 \%)$ & 0.7 & $1 / 12(=8 \%)$ & $11 / 12(=92 \%)$ \\
\hline
\end{tabular}


Two observations can be made on the basis of this table: (a) with regard to sipi (eimi) with perfect participle: contrary to what we have seen in the previous periods, the difference between the middle and the high register does not lie in a more frequent use of the anterior function in the high register. Quite surprisingly, texts of the high register contain very few examples of the construction, both with a resultative and an anterior function. (b) with regard to sipi (eimi) with aorist participle: again contrary to what we would expect, the rise of the construction (which was mainly limited to the middle register in LPG) has not resulted in a greater register spread: again, the high register contains almost no examples. In other words, the increase in frequency observed in Figure 2 must be almost entirely ascribed to the middle register. ${ }^{63}$

While it cannot be doubted that the gradual breakdown of the participial system had a profound effect on the use of periphrastic constructions, particularly those with the active participle (i.c. eiji (eimi) with aorist participle), the data presented here do not attest to any radical change in EBG, not in use or in frequency. The vitality of eipi (eimi) with aorist participle has also been noted by Horrocks (2010:131), who observes that, despite the 'withering away' of the inflected participles of the 3 rd declension, "the use of the past tense of 'be' with an aorist active participle ... is also well attested as a pluperfect substitute" (Mihevc 1959:141 writes that the construction only disappeared in the thirteenth century, when it was replaced by a periphrastic construction with है $\chi \omega(e k h \bar{o}))$. According to Giannaris (2011a:11), the fact that we do not see any traces of rigidification of the participle can be attributed to the fact that "the majority of the Early Medieval texts represent a middle register Greek rather than the spoken language of the period".

Turning to the papyri, we find that both eipi (eimi) with perfect participle and sipi (eimi) with aorist participle are infrequently attested: the former construction has completely disappeared, while for the latter there are only a few attestations. One example is given here in $(47)^{64}$

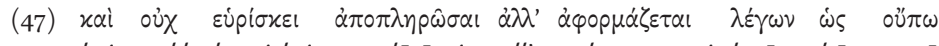
kai oukh heuriskei apoplērōsai all' aphormazetai legōn hōs oupō and not he.is.able to.pay but he.is.stalling saying that not.yet

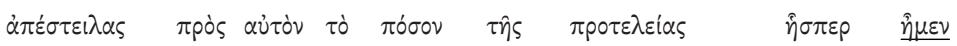
apesteilas pros auton to poson tès proteleias hèsper ềmen you.have.sent to him the amount of.the advance.payment of.which we.were

\footnotetext{
63) At present, it is unclear to me what may have caused the avoidance of both periphrastic constructions in the high register.

64) For some additional examples, see e.g. P.Lond.4.1346, l. 4-5 (710 AD); P.Ross.Georg.4.1, l. $3^{2}$ (710 AD); P.Lond.4.1419, l. 827, 1364 (716-717 AD).
} 


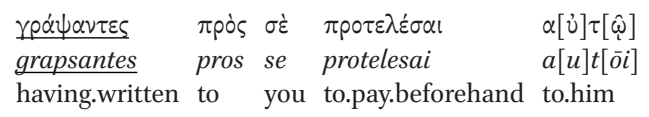

"and he is not able to pay but he is stalling, saying that you have not yet sent him the amount of the advance payment of which we had written to you to pay it beforehand to him"

(my translation/KB) (P.Lond.4.136o, 1. 7-9 (710 AD))

\subsubsection{Constructions with है $\chi \omega$ : Apparent Stability}

The constructions of $\varepsilon^{\prime} \chi \omega(e k h \bar{o})$ with passive perfect participle (catching on in MPG) and $\varepsilon^{\prime} \chi \omega(e k h \bar{o})$ with present/aorist participle and a temporal adjunct (catching on in LPG) remain more or less stable in EBG, still occurring rather infrequently. In the former case, this may be connected to the competition of functionally similar variant constructions ( i i i (eimi) with perfect and aorist participle), while in the latter case we must also take into account the fact that the construction was limited to a subfunction of the anterior perfect, the perfect of persistence (cf. §4.3.2), which is contextually less often required.

\subsubsection{1. है $\chi \omega$ with Passive Perfect Participle}

The construction of $\varepsilon^{\prime} \chi \omega(e k h \bar{o})$ with passive perfect participle does not increase in frequency during the EBG period, contrary to Jannaris' (1897:498) statement referred to in $\S 4.3 .1 .3$ (occurring with a frequency of 0.6 per 10,000 words, as in LPG). It is interesting to note that the construction can be found in all registers. Contrary to what we have seen for eiji (eimi) with aorist and perfect participle, high-register texts supply about half of the examples (being attested in writers such as John of Damascus, Sophronius, Theophylact Simocotta, Ignatius the Deacon, Michael Syncellus and Stephan the Deacon). Example (48) comes from the historiographer Theophylact Simocotta:

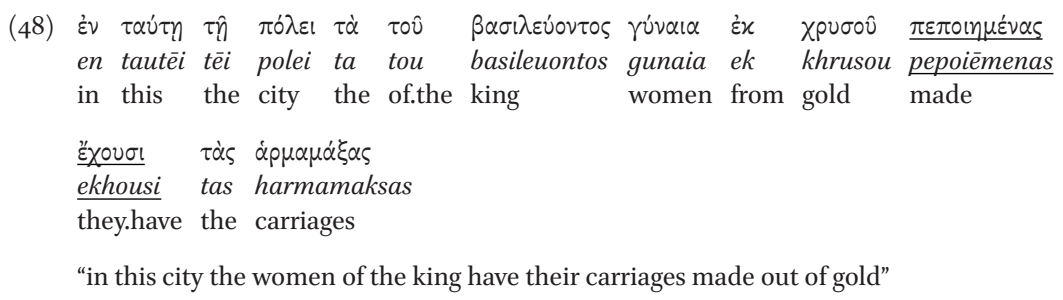

In this case, we are quite clearly dealing with a resultative perfect: in all likelihood, the wives of the king did not make their own carriages. Only in a small minority of the cases can we speak of an anterior inference, as in (49): 


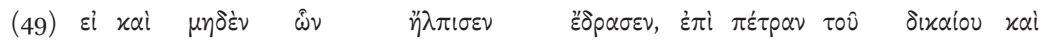
ei kai mēden hōn èlpisen edrasen, epi petran tou dikaiou kai if even nothing of.which he.hoped.for he.did on rock of.the justice and

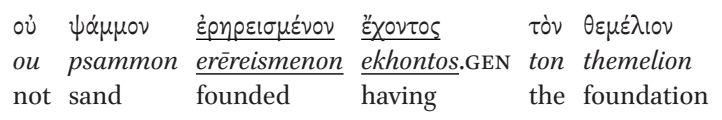

“... even if he (the devil) succeeded in nothing of the things he had hoped for, as he (Job) had fixed his foundations on the rock of justice and not on sand"

(tr. Gascou (originally in French), slightly modified) (Sophr. H., Mir. Cyr. et Jo. 15.33-35)

Even here, though, I would argue that there is still a strong resultative sense ("he had his foundation fixed", rather than "he had fixed his foundation").

In the papyri the use of the construction is restricted: I have found two in-

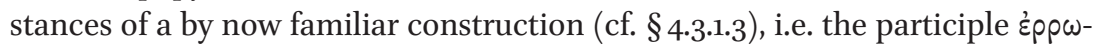
$\mu \dot{\varepsilon}^{\prime}$ os (errōmenos) ("strong") (in the accusative case) accompanied by $\tau \dot{\alpha} \varsigma \varphi \rho \varepsilon^{-}$

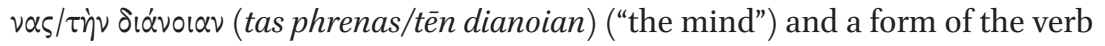
है $\chi \omega(e k h o \overline{)}$ (P.Lond.1.77, 1. 11 (ca. 610 AD); P.Lond.4.1338, 1. 16 (709 AD)).

\subsubsection{2. है $\chi \omega$ with Present/Aorist Participle}

Similarly to है $\chi \omega(e k h \bar{o})$ with passive perfect participle, this construction, catching on in LPG, remains stable (with an NRO of 0.2 per 10,000 words in both LPG and EBG). As in LPG, the construction is confined to the middle register. There is more or less a balance between the use of the present and aorist participle, with nine versus six attestations respectively. Again, the aorist participle is almost exclusively used with the negation. ${ }^{65}$ An example with the present participle is given in (50):

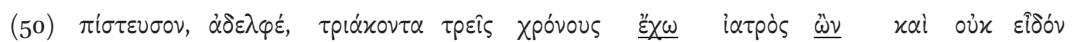
pisteuson, adelphe, triakonta treis khronous $\underline{\underline{e} k h \bar{o}}$ iatros $\underline{\bar{o} n}$ kai ouk eidon believe brother thirty three years I.have doctor being and not I.saw

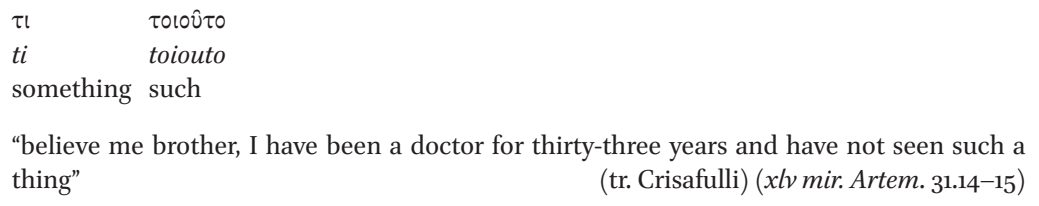

\subsubsection{First Order Variation: Alternative Periphrastic Perfect Constructions}

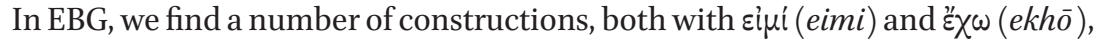
which can be discussed under the heading of 'first order variation'. These are similar to what we have encountered in LPG.

65) One exception would be $x l v$ mir. Artem. $5^{6.19}$. 
4.4.3.1. Eipi with (Passive) Present Participle (Resultative/Anterior)

As in all of the previous periods, eipi (eimi) with passive present participle is used for the resultative function. In illustration, consider $(51): 66$

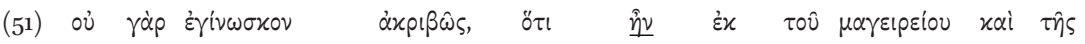
ou gar eginōskon akribōs, hoti $\underline{\bar{e} n}$ ek tou mageireiou kai tēs not for they.recognized completely because it.was from the kitchen and the

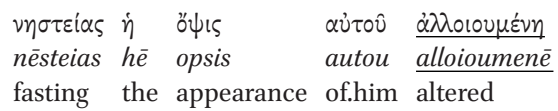

"for they did not recognize him completely, for his appearance was altered because of his job as a cook and the fasting"

(tr. Festugière, originally in French) (Leont. N., V.Jo. Eleem. 371.10-11)

In some eighth-century papyri from Aphroditopolis, Mandilaras (1973:240) has observed the presence of constructions with the verb sipi (eimi) (in the future tense) accompanied by the present participle of ह่ $\pi$ i $\sigma \tau \alpha \mu \alpha$ (epistamai) "I know", as in $\left(5^{2}\right)$ :

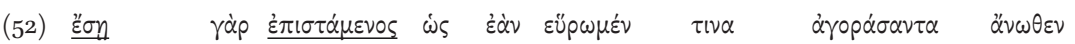
$\underline{\text { esēi }}$ gar $\underline{\text { epistamenos }}$ hōs ean heurōmen tina agorasanta anōthen you.will.be for knowing that if we.will.find someone having.bought over

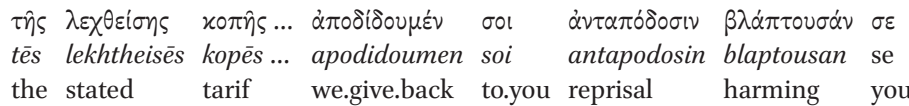

"you should be aware that (you will have learnt that?) if we discover anyone who has bought things for more than the tarif stated ... we are going to give you a harmful reprisal in return" (tr. papyri.info) (P.Ross.Georg.4.8, 1. 8-10 (710 AD))

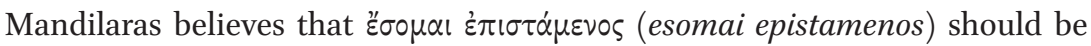
considered an innovative construction, with the semantic value of a future anterior perfect, i.e. "I will have heard/learnt". ${ }^{67} \mathrm{I}$ find this suggestion rather farfetched: future-referring हैซદı (esei) may be taken with the value of an imperative, and the participle as a regular stative present participle, with the value of English "aware". This is not to say, of course, that there are no examples of the innovative use of $\varepsilon_{i \mu i}$ (eimi) with present participle with an anterior function. Consider example (53), from Theophanes' Chronography:

66) For similar examples, see e.g. Chron. Pasch. 237.6; Georg. S., V. Theod. S. 167.77; Steph. Diac., V. Steph. 20.8.

67) Mandilaras does not seem to have noticed a similar construction with the active participle

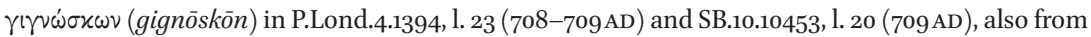
Aphroditopolis. 


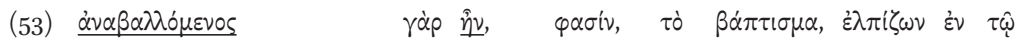
anaballomenos gar ền, phasin, to baptisma, elpizōn en tōi (deferring/)having.deferred for he.was they.say the baptism hoping in the

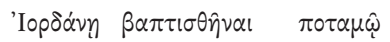

Iordanēi baptisthēnai potamōi

Jordan to.be.baptized river

"they claim that he had deferred baptism in the hope of being baptized in the river Jordan"

(tr. Mango \& Scott) (Thphn., Chron. 17.30-31)

Mango \& Scott suggest that $\alpha \nu \alpha \beta \alpha \lambda \operatorname{\beta ó}_{\mu \varepsilon v o s} \hat{\eta} \nu$ (anaballomenos èn) should be taken as an anterior perfect ("he had deferred"), which indeed seems to be indicated by the context (though perhaps a progressive interpretation must not be entirely excluded): in his discussion of the year $321 / 2 \mathrm{AD}$, Theophanes mentions that up until his time a dispute exists between the inhabitants of Old Rome and the easterners whether Constantine the Great was baptized in Rome (in this year) or rather in Nicomedia (at a later time, on his death-bed). Our example contains the easterner's (the subject of $\varphi \alpha \sigma^{\prime}(v)$ argument why Constantine would not have taken baptism in Rome at this time.

\subsubsection{2. है $\chi \omega$ with Passive Aorist Participle (Resultative)}

EBG is the first period for which I have not encountered any instances of $\varepsilon^{\prime} \chi \omega$ $(e k h \bar{o})$ with active/middle aorist participle with an anterior function (in imitation of the classical authors). What we do find is the construction of है $\chi \omega(e k h \bar{o})$ with passive aorist participle, as in (54): ${ }^{68}$

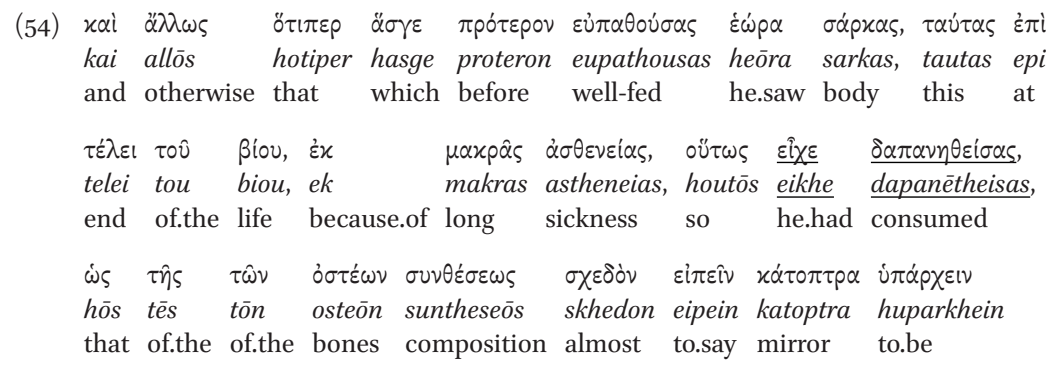

"moreover, his body, which before he saw well-fed, towards the end of his life, due to a long sickness, he had so consumed, that one would almost have said that it constituted but the mirror (reflection?) of his skeleton"

(tr. Efthymiadis (originally in French), slightly modified)

68) Cf. similarly Jo. D., Artem. 61.15-16. 


\subsubsection{3. है $\chi \omega$ with Passive Present Participle (Resultative)}

As in LPG, the construction of $\varepsilon^{\prime} \chi \omega(e k h \bar{o})$ with passive perfect participle is also extended to the passive present participle. In (55), for example, the coordination with the perfect participle $\mu \varepsilon \mu \nu \varkappa \hat{\omega} \tau \alpha$ (memukōta) strongly suggests the resultative value of $\dot{\alpha} \nu$ or $\gamma$ $\mu \varepsilon v \alpha$ (anoigomena): ${ }^{69}$

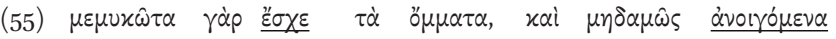 memukōta gar eskhe ta ommata, kai mēdamōs anoigomena shut for he.had the eyes and not.at.all (being).opened "he had his eyes closed and not at all opened"

(my translation/KB) (Sophr. H., Mir. Cyr. et Jo. 46.14)

\section{Conclusion}

I have given an in-depth treatment of perfect periphrases with giji (eimi) and $\varepsilon$ ह $\chi \omega(e k h \bar{o})$ on the basis of a large, register-balanced corpus of texts (including the papyri), going from the third century $\mathrm{BC}$ to the eighth century AD. For my description and analysis of these periphrastic constructions I have adopted an 'ecological-evolutionary' perspective. This framework allows us to take into account linguistic variation at two levels (innovation and propagation), and offers insight into the linguistic and social mechanisms of change.

I have argued that the diachrony of the three major periphrastic perfect con-

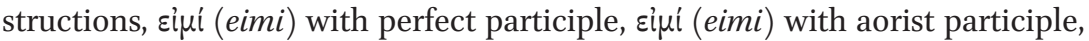
and $\varepsilon^{\prime} \chi \omega(e k h \bar{o})$ with passive perfect participle, is more complex than has traditionally been assumed. I have shown that, while gi $\mu$ i with perfect participle was the dominant periphrasis in all registers in EPG, starting from MPG the construction became functionally specialized in the middle register for the resultative function. This must have stimulated the rise of Eiji (eimi) with aorist participle as an anterior perfect periphrasis in the same register. In the high register, on the other hand, the construction of zipi (eimi) with aorist participle never gained firm ground, which can be related to the fact that (at least until LPG) $\varepsilon$ i$\mu i$ (eimi) with perfect participle remained the dominant perfect periphrasis for both aspectual functions. The construction of $\varepsilon^{\prime} \chi \omega(e k h \bar{o})$ with passive perfect participle emerged in the same period as that of zini (eimi) with aorist participle, but the functional division between the two sipi-periphrases seems to have blocked its further development.

Next to these major constructions, I have drawn attention to the existence of numerous innovative periphrastic perfect constructions, occurring (much) less frequently, such as siji (eimi) with present participle (resultative and anterior),

69) Cf. similarly Sophr. H., Mir. Cyr. et Jo. 30.135-136, 66.48, 66.49. 
है $\chi \omega(e k h \bar{o})$ with active/middle aorist participle (anterior), है $\chi \omega$ with active/middle aorist/present participle and a temporal adjunct (anterior (perfect of persistence)), है $\chi \omega$ with passive aorist participle (resultative) and $\varepsilon^{\prime} \chi \omega(e k h \bar{o})$ with passive present participle (resultative). Most of these innovations can be related to the mechanism of intraference, and must have been stimulated by developments in the participial system. है $\chi \omega(e k h \bar{o})$ with active/middle aorist/present participle and a temporal adjunct, on the other hand, is a case of form-function reanalysis, while $\varepsilon^{\prime} \chi \omega(e k h \bar{o})$ with active/middle aorist participle seems to have been reintroduced in imitation of the classical authors.

As Garner (2004:62-63) notes, the choice for a holistic, ecological approach does not entail examining everything: "holistic does not mean exhaustive: it is not a matter of quantity, but of quality of vision. We have to limit our focus, to give attention to some things and not others; our descriptions and analyses will always be partial". Much remains to be done in the field of perfect periphrases: the corpus needs to be expanded, the development of the synthetic tenses must be charted much more accurately, and other periphrastic constructions

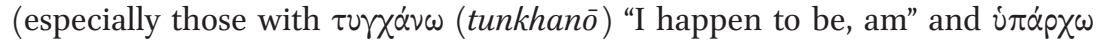
(huparkhō) "I am") need to be involved.

\section{References}

Adrados, Francisco R. 2005. A history of the Greek language: From its origins to the present. Leiden: Brill.

Aerts, Willem J. 1965. Periphrastica. Amsterdam: Hakkert (diss. Amsterdam).

Bentein, Klaas. 2012. The periphrastic perfect in Ancient Greek. A diachronic mental space analysis. Transactions of the Philological Society 110: 171-211.

Bentein, Klaas. forthc. On the construction of HAVE with passive perfect participle in Greek and Latin. To appear in Eranos: Acta Philologica Suecana.

Biber, Douglas and Susan Conrad. 2009. Register, genre, and style. Cambridge: Cambridge University Press.

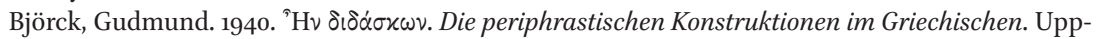
sala: Almqvist \& Wiksell (diss. Uppsala).

Browning, Robert. 1969. Medieval and modern Greek. Cambridge: Cambridge University Press.

Bybee, Joan \& Östen Dahl. 1989. The creation of tense and aspect systems in the languages of the world. Studies in Language 13: 51-103.

Bybee, Joan, Perkins, Revere and William Pagliuca. 1994. The evolution of grammar: Tense, aspect, and modality in the languages of the world. Chicago (Ill.): University of Chicago press.

Cameron, Averil. 1991. Christianity and the rhetoric of empire: The development of Christian discourse. Berkeley (Calif.): University of California press.

Chomsky, Noam. 1965. Aspects of the theory of syntax. Cambridge (Mass.): MIT press.

Coetsem, Frans van. 2000. A general and unified theory of the transmission process in language contact. Heidelberg: Winter.

Cox, Patricia. 1983. Biography in Late Antiquity: A quest for the holy man. Berkeley (Calif.): University of California Press.

Croft, William. 2000. Explaining language change: An evolutionary approach. Harlow, Essex: Longman. 
Croft, William. 2002. The Darwinization of linguistics. Selection 3: 75-91.

Croft, William. 2006a. The relevance of an evolutionary model to historical linguistics. In O. Nedergård Thomsen (ed.), Different models of linguistic change, 91-132. Amsterdam: John Benjamins.

Croft, William. 2006b. Evolutionary models and functional-typological theories of language change. In A. van Kemenade \& B. Los (eds.), Handbook of the History of English, 68-91. Oxford: Blackwell.

Dickey, Eleanor. 2003. Latin influence on the Greek of documentary papyri: An analysis of its chronological distribution. Zeitschrift für Papyrologie und Epigraphik 145: 249-257.

Dickey, Eleanor. 2009. The Greek and Latin languages in the papyri. In R.S. Bagnall (ed.), Oxford handbook of papyrology, 149-169. New York: Oxford University Press.

Dieterich, Karl. 1898. Untersuchungen zur Geschichte der griechischen Sprache: Von der hellenistischen Zeit bis zum 10. Jahrhundert n. Chr. Leipzig: Teubner.

Drinka, Bridget. 2007. The development of the HAVE perfect: Mutual influences of Greek and Latin. In R. Aranovich (ed.), Split auxiliary systems: A cross-linguistic perspective, 101-121. Amsterdam: Benjamins.

Duhoux, Yves. 200o. Le verbe grec ancien. Louvain-La-Neuve: Peeters.

Evans, Trevor V. 2001. Verbal syntax in the Greek Pentateuch: Natural Greek usage and Hebrew interference. Oxford: Oxford University Press.

Fleischman, Suzanne. 2000. Methodologies and ideologies in historical linguistics: On working with older languages. In S.C. Herring, P. van Reenen and L. Schøsler (eds.), Textual parameters in older languages, 33-58. Amsterdam: Benjamins.

Frank, Roslyn M. and Nathalie Gontier. 2010. On constructing a research model for Historical Cognitive Linguistics (HCL): Some theoretical considerations. In M.E. Winter, H. Tissari and K. Allan (eds.), Historical Cognitive Linguistics, 31-69. Berlin, de Gruyter/Mouton.

Friedrich, Paul. 1974. On aspect theory and Homeric aspect. International Journal of American Linguistics 40: 1-44.

Garner, Mark. 2004. Language: An ecological view. New York: Peter Lang.

Garner, Mark. 2005. Language ecology as linguistic theory. Kajian Linguistik dan Sastra 17: 91101.

Gerö, Eva-Carin and Arnim von Stechow. 2003. Tense in time: The Greek perfect. In R. Eckardt, K. von Heusinger and C. Schwarze (eds.), Words in time: Diachronic semantics from different points of view, 251-294. Berlin: Mouton de Gruyter.

Ghedini, Giuseppe. 1937. La lingua dei vangeli apocrifi greci. In Studi dedicati alla memoria di Paolo Ubaldi, 443-480. Milano: Vita e pensiero.

Giannaris, Athanasios. 2011a. Pluperfect periphrases in Medieval Greek: A perspective on the collaboration between linguistics and philology. Transactions of the Philological Society 109: $1-14$.

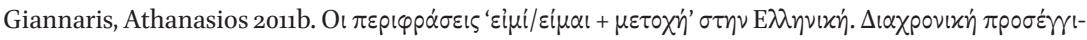
$\sigma \eta$. Ph.D. thesis, University of Athens.

Habermann, Wolfgang. 1998. Zur chronologischen Verteilung der papyrologischen Zeugnisse. Zeitschrift für Papyrologie und Epigraphik 122: 144-160.

Haspelmath, Martin. 1992. From resultative to perfect in Ancient Greek. In J.L. Iturrioz Leza (ed.), Nuevos estudios sobre construcciones resultativos (= Función 11-12), 187-224. Universidad de Guadalajara: Centro de Investigación de Lenguas Indígenas.

Haspelmath, Martin. 1999. Optimality and diachronic adaptation. Zeitschrift für Sprachwissenschaft 18: 180-205.

Haverling, Gerd. 2009. Actionality, tense, and viewpoint. In P. Cuzzolin and P. Baldi (eds.), New perspectives on historical Latin syntax, vol. 2, Constituent syntax: adverbial phrases, adverbs, mood, tense, 277-523. Berlin \& New York: Mouton de Gruyter.

Herring, Susan C., van Reenen, Pieter and Lene Schøsler. 2000. On textual parameters and older 
languages. In S.C. Herring, P. van Reenen and L. Schøsler (eds.), Textual parameters in older languages, 1-31. Amsterdam: John Benjamins

Høgel, Christian. 2002. Symeon Metaphrastes: Rewriting and canonisation. Copenhagen: Museum Tusculanum Press.

Horrocks, Geoffrey. 2010². Greek: A history of the language and its speakers. Oxford \& Malden, Mass.: Wiley-Blackwell.

Hruschka, Daniel J., Christiansen, Morten, Blythe, Richard, Croft, William, Heggarty, Paul, Mufwene, Salikoko, Pierrehumbert, Janet and Shana Poplack. 2009. Building social cognitive models of language change. Trends in Cognitive Sciences 13: 464-469.

Jannaris, Antonius N. 1897. An historical Greek grammar chiefly of the Attic dialect. Hildesheim: Olms.

Keller, Rudi. 1994. On language change: The invisible hand in language. London: Routledge.

Lampe, Geoffrey W.H. 1976. A patristic Greek lexicon. Oxford: Clarendon.

Lee, John A.L. 2007. 'E $\xi \alpha \tau 0 \sigma \tau \dot{\varepsilon} \lambda \omega \omega$. In J. Joosten and P.J. Tomson (eds.), Voces Biblicae: Septuagint Greek and its significance for the New Testament, 99-113. Leuven: Peeters.

Mandilaras, Basil G. 1972. Studies in the Greek language. Some aspects of the development of the Greek language up to the present day. Athens: N. Xenopoulos Press.

Mandilaras, Basil G. 1973. The verb in the Greek non-literary papyri. Athens: Hellenic Ministry of Culture and Sciences.

Manolessou, Io. 2005. From participles to gerunds. In M. Stavrou and A. Terzi (eds.), Advances in Greek generative syntax, 241-283. Amsterdam: John Benjamins.

Manolessou, Io. 2008. On historical linguistics, linguistic variation and Medieval Greek. Byzantine and Modern Greek Studies 32: 63-79.

Markopoulos, Theodore. 2009. The future in Greek. From Ancient to Medieval. Oxford: Oxford University Press.

McKay, Kenneth L. 1980. On the perfect and others aspects in the Greek non-literary papyri. Bulletin of the Institute of Classical Studies 27: 23-49.

McMahon, April. 1994. Understanding language change. Cambridge: Cambridge University Press.

Mihevc, Erika. 1959. La disparition du parfait dans le grec de la basse époque. Ljubljana: Slovenka Akademija znanosti in umetnosti. Razred filološke in literarne vede.

Milroy, James and Leslie Milroy 1985. Linguistic change, social network and speaker innovation. Journal of Linguistics 21: 339-384.

Mirambel, André. 1961. Participe et gérondif en grec médiéval et moderne. Bulletin de la Société Linguistique de Paris 56: 46-79.

Mirambel, André. 1966. Essai sur l'évolution du verbe en grec byzantin. Bulletin de la Société Linguistique de Paris 61: 167-190.

Moser, Amalia. 1988. A history of the perfect periphrases in Greek. Ph.D. Thesis, University of Cambridge.

Moser, Amalia. 2009. 'A

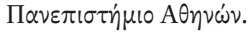

Mufwene, Salikoko. 2001. The ecology of language evolution. Cambridge: Cambridge University Press.

Mufwene, Salikoko. 2008. Language evolution: Contact, competition, and change. London: Continuum.

Nettle, Daniel. 1999. Linguistic diversity. Oxford: Oxford University Press.

O'Donnell, Matthew. 2000. Designing and compiling a register-balanced corpus of Hellenistic Greek for the purpose of linguistic description and investigation. In S.E. Porter (ed.), Diglossia and other topics in New Testament linguistics, 255-297. Sheffield: Sheffield Academic Press.

Palme, Bernhard. 2009. The range of documentary texts: Types and categories. In R.S. Bagnall (ed.), Oxford handbook of papyrology, 358-394. New York: Oxford University Press.

Pinkster, Harm. 1987. The strategy and chronology of the development of future and perfect tense 
auxiliaries in Latin. In M. Harris and P. Ramat (eds.), The historical development of auxiliaries, 193-223. Berlin: Mouton de Gruyter.

Porter, Stanley E. 1989. Verbal aspect in the Greek of the New Testament, with reference to tense and mood. New York: Peter Lang (diss. Sheffield).

Rosenqvist, Jan O. 2007. Die byzantinische Literatur: Vom 6. Jahrhundert bis zum Fall Konstantinopels 1453. Berlin and New York: Walter de Gruyter.

Ruijgh, Cornelis. 2004. Over de gebruikswijzen van het Griekse perfectum. Met speciale aandacht voor Plato's Politeia. Lampas 37: 24-45.

Salonius, Aarne H. 1927. Zur Sprache der griechischen Papyrusbriefe. Helsingfors: Akademische Buchhandlung.

Smyth, Herbert W. 1984[1920]. Greek grammar. Revised by Gordon M. Messing. Harvard: Harvard University Press.

Tabachowitz, David. 1943. Études sur le grec de la basse époque. Uppsala: Almqvist and Wiksell.

Thackeray, Henry. 1909. A grammar of the Old Testament in Greek according to the Septuagint. Cambridge: Cambridge University Press.

Thielmann, Philipp. 1891. "E $\chi \omega$ mit Particip. In Abhandlungen aus dem Gebiet der klassischen Altertums-Wissenschaft, 294-306. München: Beck.

Traugott, Elizabeth C. and Richard B. Dasher. 2002. Regularity in semantic change. Cambridge: Cambridge University Press.

White, John L. 1972. The form and structure of the official petition: A study in greek epistolography. Missoula (Mont.): Soc. of biblical literature.

Willi, Andreas. 2003. The languages of Aristophanes: Aspects of linguistic variation in Classical Attic Greek. Oxford: Oxford University Press.

Willi, Andreas. 2010. Register variation. In E.J. Bakker (ed.), The Blackwell companion to the Ancient Greek Language, 297-310. Oxford: Blackwell.

Wolf, Karl. 1912. Studien zur Sprache des Malalas. München: Straub.

\section{Primary (Literary) Sources}

Early Post-Classical Greek (III-IBC)

\begin{tabular}{llll}
\hline Septuagint & III/II BC & $\begin{array}{l}\text { A. Rahlfs. 1935. Septuaginta, 9th edn. } \\
\text { Stuttgart: Württemberg Bible Society. }\end{array}$ \\
\hline Histories & Polybius & III/II BC & $\begin{array}{l}\text { T. Büttner-Wobst. 1882-1904. Polybii } \\
\text { historiae. Leipzig: Teubner. }\end{array}$ \\
\hline Apocalypse of Enoch & & II/I BC & $\begin{array}{l}\text { M. Black. 1970. Apocalypsis Henochi Graece. } \\
\text { Leiden: Brill. }\end{array}$ \\
\hline Roman Antiquities & Dionysius of & I BC & $\begin{array}{l}\text { K. Jacoby. 1885-1905. Dionysii Halicarnasei } \\
\text { antiquitatum Romanarum quae supersunt. } \\
\text { Lalicarnassus }\end{array}$ \\
& & Leipzig: Teubner. \\
\hline Life of Adam and Eve & & I BC/I AD & $\begin{array}{l}\text { C. Tischendorf. 1866. Apocalypses } \\
\text { apocryphae. Leipzig: Mendelssohn. }\end{array}$ \\
& & &
\end{tabular}


Middle Post-Classical Greek (I-IIIAD)

\begin{tabular}{|c|c|c|}
\hline Apocalypse of Baruch & $\mathrm{IAD}$ & $\begin{array}{l}\text { J.C. Picard. 1967. Apocalypsis Baruchi } \\
\text { Graece. Leiden: Brill. }\end{array}$ \\
\hline New Testament & $\mathrm{IAD}$ & $\begin{array}{l}\text { K. Aland, M. Black, C.M. Martini, } \\
\text { B.M. Metzger \& A. Wikgren. 1968. The } \\
\text { Greek New Testament, 2nd edn. Stuttgart: } \\
\text { Württemberg Bible Society. }\end{array}$ \\
\hline Testament of Abraham & $\mathrm{IAD}$ & $\begin{array}{l}\text { M.R. James. } 1892 . \text { The testament of } \\
\text { Abraham. Cambridge: Cambridge University } \\
\text { Press. }\end{array}$ \\
\hline Parallel lives $^{70}$ & $\mathrm{I} / \mathrm{II} \mathrm{AD}$ & $\begin{array}{l}\text { K. Ziegler. 1964-1971. Plutarchi vitae } \\
\text { parallelae, 2nd edn. Leipzig: Teubner. } \\
\text { / B. Perrin. 1914-1926. Plutarch's lives. } \\
\text { Cambridge (Mass.): Harvard University } \\
\text { Press. }\end{array}$ \\
\hline Acts of Andrew & $\mathrm{IIAD}$ & $\begin{array}{l}\text { J.-M. Prieur. 1989. Acta Andreae. Turnhout: } \\
\text { Brepols. }\end{array}$ \\
\hline Acts ofJohn & II AD & $\begin{array}{l}\text { M. Bonnet. 1898. Acta apostolorum } \\
\text { apocrypha. Leipzig: Mendelssohn. }\end{array}$ \\
\hline Acts of Paul & II AD & $\begin{array}{l}\text { C. Schmidt \& W. Schubart. 1936. Acta Pauli. } \\
\text { Glückstadt: Augustin. }\end{array}$ \\
\hline $\begin{array}{l}\text { Acts of Paul and } \\
\text { Thecla }\end{array}$ & II AD & $\begin{array}{l}\text { R.A. Lipsius. 1891. Acta apostolorum } \\
\text { apocrypha. Leipzig: Mendelssohn. }\end{array}$ \\
\hline Apocalypse ofJohn & II AD & $\begin{array}{l}\text { C. Tischendorf. 1866. Apocalypses } \\
\text { apocryphae. Leipzig: Mendelssohn. }\end{array}$ \\
\hline $\begin{array}{l}\text { Acts of the Scillitan } \\
\text { martyrs }\end{array}$ & II AD & $\begin{array}{l}\text { J.A. Robinson. } 1891 . \text { The passion of } \\
\text { S. Perpetua. Cambridge: Cambridge } \\
\text { University Press. }\end{array}$ \\
\hline $\begin{array}{l}\text { Confession and prayer } \\
\text { of Aseneth }\end{array}$ & IIAD & $\begin{array}{l}\text { M. Philonenko. 1968. Joseph et Aséneth. } \\
\text { Leiden: Brill. }\end{array}$ \\
\hline Gospel of Peter & II AD & $\begin{array}{l}\text { M.G. Mara. 1973. Évangile de Pierre. Paris: } \\
\text { Éditions du Cerf. }\end{array}$ \\
\hline Gospel of Thomas & II AD & $\begin{array}{l}\text { E. Klostermann. } 1910 . \\
\text { Apocrypha II. Evangelien, 2nd edn. Bonn: } \\
\text { Marcus \& Weber. }\end{array}$ \\
\hline Martyrdom of Paul & II AD & $\begin{array}{l}\text { R.A. Lipsius. } 1891 . \text { Acta apostolorum } \\
\text { apocrypha. Leipzig: Mendelssohn. }\end{array}$ \\
\hline Martyrdom of Peter & II AD & $\begin{array}{l}\text { L. Vouaux. 1922. Les actes de Pierre. Paris: } \\
\text { Letouzey \& Ané. }\end{array}$ \\
\hline
\end{tabular}

70) For Plutarch, I have concentrated on the lives of Agis and Cleomenes, Alexander, Antony, Caesar, Camillus, Cato the younger, Dion, Lucullus, Marius and Pompey. 


\begin{tabular}{|c|c|c|c|}
\hline $\begin{array}{l}\text { Proto-evangelium of } \\
\text { James }\end{array}$ & & II AD & $\begin{array}{l}\text { É. de Strycker. } 1961 . \text { La forme la plus } \\
\text { ancienne du protévangile de Jacque. Brussels: } \\
\text { Société des Bollandistes. }\end{array}$ \\
\hline Testament ofJob & & II AD & $\begin{array}{l}\text { S.P. Brock. 1967. Testamentum Jobi. Leiden: } \\
\text { Brill. }\end{array}$ \\
\hline Acts ofJustin & & II/III AD & $\begin{array}{l}\text { H. Musurillo. 1972. The acts of the Christian } \\
\text { martyrs. Oxford: Clarendon Press. }\end{array}$ \\
\hline $\begin{array}{l}\text { Acts of the } \\
\text { Alexandrines }\end{array}$ & & II/III AD & $\begin{array}{l}\text { H. Musurillo. 1961. Acta Alexandrinorum. } \\
\text { Leipzig: Teubner. }\end{array}$ \\
\hline Roman Histories & Cassius Dio & II/III AD & $\begin{array}{l}\text { U.P. Boissevain. 1895-1901. Cassii Dionis } \\
\text { Cocceiani historiarum Romanarum quae } \\
\text { supersunt. Berlin: Weidmann. }\end{array}$ \\
\hline
\end{tabular}

Late Post-Classical Greek (IV-VIAD)

\begin{tabular}{|c|c|c|c|}
\hline Acts of Philip ${ }^{71}$ & & IVAD & $\begin{array}{l}\text { M. Bonnet. 1903. Acta apostolorum } \\
\text { apocrypha, vol. 2.2. Leipzig: Mendelssohn. / } \\
\text { F. Amsler, B. Bouvier \& F. Bovon. 1999. Acta } \\
\text { Philippi. Turnhout: Brepols. }\end{array}$ \\
\hline $\begin{array}{l}\text { Collection of ancient } \\
\text { martyrdoms }\end{array}$ & Eusebius & IVAD & $\begin{array}{l}\text { J.-P. Migne. 1857-1866. Patrologiae cursus } \\
\text { completus (series Graeca) (MPG) 20. Paris: } \\
\text { Migne. }\end{array}$ \\
\hline Ecclesiastical history & Eusebius & IVAD & $\begin{array}{l}\text { G. Bardy. 1952-1958. Eusèbe de Césarée. } \\
\text { Histoire ecclésiastique. Paris: Éditions du } \\
\text { Cerf. }\end{array}$ \\
\hline $\begin{array}{l}\text { Encomium on the holy } \\
\text { forty martyrs }\end{array}$ & $\begin{array}{l}\text { Ephraem the } \\
\text { Syrian }\end{array}$ & IVAD & 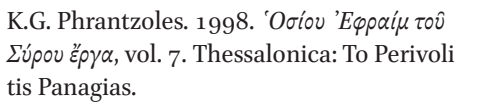 \\
\hline Lausiac history & Palladius & IVAD & $\begin{array}{l}\text { G.J.M. Bartelink. 1974. Palladio. La storia } \\
\text { Lausiaca. Verona: Fondazione Lorenzo Valla. }\end{array}$ \\
\hline Life of Antony & Athanasius & IVAD & $\begin{array}{l}\text { G.J.M. Bartelink. 2004. Athanase } \\
\text { d'Alexandrie, Vie d'Antoine. Paris: Éditions } \\
\text { du Cerf. }\end{array}$ \\
\hline Life of Constantine & Eusebius & IVAD & $\begin{array}{l}\text { F. Winkelmann. 1975. Eusebius Werke, Band } \\
\text { 1.1: Über das Leben des Kaisers Konstantin. } \\
\text { Berlin: Akademie Verlag. }\end{array}$ \\
\hline Life of St. Macrina & $\begin{array}{l}\text { Gregory of } \\
\text { Nyssa }\end{array}$ & IVAD & $\begin{array}{l}\text { P. Maraval. 1971. Grégoire de Nysse. Vie de } \\
\text { sainte Macrine. Paris: Éditions du Cerf. }\end{array}$ \\
\hline
\end{tabular}

71) I have taken into account the version based on the Xenophont. 32 and that based on the Vatic. gr. 824 . 


\begin{tabular}{|c|c|c|c|}
\hline $\begin{array}{l}\text { Martyrium of Pionius } \\
\text { the presbyter and his } \\
\text { comrades }\end{array}$ & & IVAD & $\begin{array}{l}\text { H. Musurillo. 1972. The acts of the Christian } \\
\text { martyrs. Oxford: Clarendon Press. }\end{array}$ \\
\hline On Gordius the Martyr & $\begin{array}{l}\text { Basil of } \\
\text { Caesarea }\end{array}$ & IVAD & $\begin{array}{l}\text { J.-P. Migne. 1857-1866. Patrologiae cursus } \\
\text { completus (series Graeca) (MPG) 31. Paris: } \\
\text { Migne. }\end{array}$ \\
\hline $\begin{array}{l}\text { On the life of blessed } \\
\text { Abraham and his } \\
\text { granddaughter Maria }\end{array}$ & $\begin{array}{l}\text { Ephraem the } \\
\text { Syrian }\end{array}$ & IVAD & 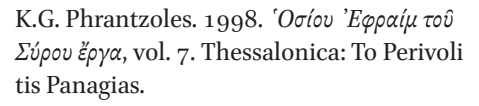 \\
\hline $\begin{array}{l}\text { On the life of Gregory } \\
\text { the Wonderworker }\end{array}$ & $\begin{array}{l}\text { Gregory of } \\
\text { Nyssa }\end{array}$ & IVAD & $\begin{array}{l}\text { J.-P. Migne. 1857-1866. Patrologiae cursus } \\
\text { completus (series Graeca) (MPG) 46. Paris: } \\
\text { Migne. }\end{array}$ \\
\hline On the life of Moses & $\begin{array}{l}\text { Gregory of } \\
\text { Nyssa }\end{array}$ & IVAD & $\begin{array}{l}\text { J. Danielou. 1968. Grégoire de Nysse. La vie } \\
\text { de Mö̈se, 3rd edn. Paris: Éditions du Cerf. }\end{array}$ \\
\hline $\begin{array}{l}\text { On the martyrs of } \\
\text { Palestine }\end{array}$ & Eusebius & IVAD & $\begin{array}{l}\text { G. Bardy. 1958. Eusèbe de Césarée. Histoire } \\
\text { ecclésiastique, vol. 3. Paris: Éditions du Cerf. }\end{array}$ \\
\hline Historical fragments & Eunapius & $\mathrm{IV} / \mathrm{VAD}$ & $\begin{array}{l}\text { L. Dindorf. 1870. Historici Graeci minores, } \\
\text { vol. 1. Leipzig: Teubner. }\end{array}$ \\
\hline Ecclesiastical history & $\begin{array}{l}\text { Theodoretus of } \\
\text { Cyrrhus }\end{array}$ & IV/VAD & $\begin{array}{l}\text { L. Parmentier \& F. Scheidweiler. } 1954 . \\
\text { Theodoret. Kirchengeschichte, 2nd edn. } \\
\text { Berlin: Akademie Verlag. }\end{array}$ \\
\hline $\begin{array}{l}\text { On those who in } \\
\text { Euphratesia and the } \\
\text { Osrhoene region, } \\
\text { Syria, Phoenicia } \\
\text { and Cilicia live the } \\
\text { monastic life }\end{array}$ & $\begin{array}{l}\text { Theodoretus of } \\
\text { Cyrrhus }\end{array}$ & $\mathrm{IV} / \mathrm{VAD}$ & $\begin{array}{l}\text { J.-P. Migne. 1857-1866. Patrologiae cursus } \\
\text { completus (series Graeca) (MPG) 83. Paris: } \\
\text { Migne. }\end{array}$ \\
\hline Acts of Barnabas & & $\mathrm{VAD}$ & $\begin{array}{l}\text { M. Bonnet. 1903. Acta apostolorum } \\
\text { apocrypha, vol. 2.2. Leipzig: Mendelssohn. }\end{array}$ \\
\hline Ecclesiastical history & Sozomenus & $\mathrm{VAD}$ & $\begin{array}{l}\text { J. Bidez \& G.C. Hansen. 196o. Sozomenus. } \\
\text { Kirchengeschichte. Berlin: Akademie Verlag. }\end{array}$ \\
\hline $\begin{array}{l}\text { Encomium on John the } \\
\text { Baptist }\end{array}$ & $\begin{array}{l}\text { Chrysippus of } \\
\text { Jerusalem }\end{array}$ & $\mathrm{VAD}$ & $\begin{array}{l}\text { A. Sigalas. 1937. Des Chrysippos von } \\
\text { Jerusalem Enkomion aufden hl. } \\
\text { Johannes den Täufer. Athens: Verlag der } \\
\text { Byzantinisch-neugriechischen Jahrbücher. }\end{array}$ \\
\hline $\begin{array}{l}\text { Encomium on St. } \\
\text { Theodorus }\end{array}$ & $\begin{array}{l}\text { Chrysippus of } \\
\text { Jerusalem }\end{array}$ & $\mathrm{VAD}$ & $\begin{array}{l}\text { A. Sigalas. 1921. Des Chrysippos von } \\
\text { Jerusalem Enkomion aufden heiligen } \\
\text { Theodoros Teron. Leipzig: Teubner. }\end{array}$ \\
\hline $\begin{array}{l}\text { History of the monks in } \\
\text { Egypt }\end{array}$ & & $\mathrm{VAD}$ & $\begin{array}{l}\text { A.-J. Festugière. 1971. Historia monachorum } \\
\text { in Aegypto. Brussels: Société des } \\
\text { Bollandistes. }\end{array}$ \\
\hline $\begin{array}{l}\text { Laudation on mother } \\
\text { Mary }\end{array}$ & Proclus & VAD & $\begin{array}{l}\text { F.J. Leroy. 1967. L'homilétique de Proclus de } \\
\text { Constantinople. Vatican City: Biblioteca } \\
\text { Apostolica Vaticana. }\end{array}$ \\
\hline
\end{tabular}




\begin{tabular}{|c|c|c|c|}
\hline Life of Alexander & & VAD & $\begin{array}{l}\text { E. de Stoop. 1911. Vie d'Alexandre l'Acémète. } \\
\text { Turnhout: Brepols. }\end{array}$ \\
\hline Life of Pachomius & & $\mathrm{VAD}$ & $\begin{array}{l}\text { F. Halkin. 1982. Le corpus athénien de saint } \\
\text { Pachome. Genève: Cramer. }\end{array}$ \\
\hline $\begin{array}{l}\text { Life of Porphyry bishop } \\
\text { of Gaza }\end{array}$ & $\begin{array}{l}\text { Mark the } \\
\text { Deacon }\end{array}$ & $\mathrm{VAD}$ & $\begin{array}{l}\text { H. Gregoire \& M.-A. Kugener. 193o. Marc le } \\
\text { Diacre. Vie de Porphyre, évêque de Gaza. } \\
\text { Paris: Les Belles Lettres. }\end{array}$ \\
\hline Life of St. Hypatius & Callinicus & VAD & $\begin{array}{l}\text { G.J.M. Bartelink. 1971. Callinicos. Vie } \\
\text { d'Hypatios. Paris: Éditions du Cerf. }\end{array}$ \\
\hline Life of St. Syncletica & $\begin{array}{l}\text { Pseudo- } \\
\text { Athanasius }\end{array}$ & VAD & $\begin{array}{l}\text { L. Abelarga. 2002. The Life of Saint } \\
\text { Syncletica. Introduction-Critical } \\
\text { Text-Commentary. Thessalonica: Centre for } \\
\text { Byzantine Research. }\end{array}$ \\
\hline $\begin{array}{l}\text { Life of Symeon Stylites } \\
\text { the Elder }\end{array}$ & $\begin{array}{l}\text { Antony the } \\
\text { Hagiographer }\end{array}$ & VAD & $\begin{array}{l}\text { H. Lietzmann. 19o8. Das Leben des heiligen } \\
\text { Symeon Stylites. Leipzig: Hinrichs. }\end{array}$ \\
\hline New History & Zosimus & $\mathrm{VAD}$ & $\begin{array}{l}\text { F. Paschoud. 1971-1989. Zosime. Histoire } \\
\text { nouvelle, vols. 1-3.2. Paris: Les Belles Lettres. }\end{array}$ \\
\hline $\begin{array}{l}\text { Passion of Gregory the } \\
\text { Illuminator }\end{array}$ & Agathangelus & VAD & $\begin{array}{l}\text { G. Garitte. 1946. Documents pour l'étude } \\
\text { du livre d'Agathange. Rome: Bibliotheca } \\
\text { Apostolica Vaticana. }\end{array}$ \\
\hline Life of Isidorus & Damascius & V/VIAD & $\begin{array}{l}\text { C. Zintzen. 1967. Damascii vitae Isidori } \\
\text { reliquiae. Hildesheim: Olms. }\end{array}$ \\
\hline Chronography & John Malalas & VIAD & $\begin{array}{l}\text { L. Dindorf. 1831. Ioannis Malalae } \\
\text { chronographia. Bonn: Weber. }\end{array}$ \\
\hline $\begin{array}{l}\text { Laudation of } \\
\text { Theodorus Graptus }\end{array}$ & $\begin{array}{l}\text { Theophanes of } \\
\text { Caesarea }\end{array}$ & VIAD & $\begin{array}{l}\text { J. Featherstone. } 1980 \text {. The praise of } \\
\text { Theodore Graptos by Theophanes } \\
\text { of Caesarea. Analecta Bollandiana } 98 \text {, } \\
104-150 .\end{array}$ \\
\hline Life of Abramius & $\begin{array}{l}\text { Cyril of } \\
\text { Scythopolis }\end{array}$ & VIAD & $\begin{array}{l}\text { E. Schwartz. 1939. Kyrillos von Skythopolis. } \\
\text { Leipzig: Hinrichs. }\end{array}$ \\
\hline Life of Cyriacus & $\begin{array}{l}\text { Cyril of } \\
\text { Scythopolis }\end{array}$ & VI AD & $\begin{array}{l}\text { E. Schwartz. 1939. Kyrillos von Skythopolis. } \\
\text { Leipzig: Hinrichs. }\end{array}$ \\
\hline Life of Euthymius & $\begin{array}{l}\text { Cyril of } \\
\text { Scythopolis }\end{array}$ & VIAD & $\begin{array}{l}\text { E. Schwartz. 1939. Kyrillos von Skythopolis. } \\
\text { Leipzig: Hinrichs. }\end{array}$ \\
\hline $\begin{array}{l}\text { Life ofJohn the } \\
\text { Silentiary }\end{array}$ & $\begin{array}{l}\text { Cyril of } \\
\text { Scythopolis }\end{array}$ & VI AD & $\begin{array}{l}\text { E. Schwartz. 1939. Kyrillos von Skythopolis. } \\
\text { Leipzig: Hinrichs. }\end{array}$ \\
\hline Life of Sabas & $\begin{array}{l}\text { Cyril of } \\
\text { Scythopolis }\end{array}$ & VIAD & $\begin{array}{l}\text { E. Schwartz. 1939. Kyrillos von Skythopolis. } \\
\text { Leipzig: Hinrichs. }\end{array}$ \\
\hline $\begin{array}{l}\text { Life of Symeon Stylites } \\
\text { the Younger }\end{array}$ & & VI AD & $\begin{array}{l}\text { P. van den Ven. 1962. La vie ancienne de } \\
\text { S. Syméon Stylite le jeune }(521-592) . \\
\text { Bruxelles: Société des Bollandistes. }\end{array}$ \\
\hline Life of Theodosius & $\begin{array}{l}\text { Cyril of } \\
\text { Scythopolis }\end{array}$ & VIAD & $\begin{array}{l}\text { E. Schwartz. 1939. Kyrillos von Skythopolis. } \\
\text { Leipzig: Hinrichs. }\end{array}$ \\
\hline
\end{tabular}




\begin{tabular}{|c|c|c|c|}
\hline Life of Eutychius & $\begin{array}{l}\text { Eustratius the } \\
\text { Presbyter }\end{array}$ & VI/VII AD & $\begin{array}{l}\text { C. Laga. 1992. Eustratii presbyteri vita } \\
\text { Eutychii patriarchae Constantinopolitani. } \\
\text { Turnhout: Brepols. }\end{array}$ \\
\hline Life of Golinduch & $\begin{array}{l}\text { Eustratius the } \\
\text { Presbyter }\end{array}$ & VI/VII AD & 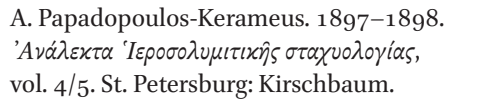 \\
\hline $\begin{array}{l}\text { Life of Martha the } \\
\text { mother of Simeon } \\
\text { Stylites the Younger }\end{array}$ & & VI/VII AD & $\begin{array}{l}\text { P. van den Ven. 197o. La vie ancienne de } \\
\text { S. Syméon Stylite le jeune, vol. 2. Brussels: } \\
\text { Société des Bollandistes. }\end{array}$ \\
\hline Life of Tycho & $\begin{array}{l}\text { John the } \\
\text { Merciful }\end{array}$ & VI/VII AD & $\begin{array}{l}\text { H. Usener. 1907. Sonderbare Heilige I. Der } \\
\text { heilige Tychon. Leipzig: Teubner. }\end{array}$ \\
\hline Spiritual Meadow & John Moschus & VI/VIIAD & $\begin{array}{l}\text { J.-P. Migne. 1857-1866. Patrologiae cursus } \\
\text { completus (series Graeca) (MPG) 87.3. Paris: } \\
\text { Migne. }\end{array}$ \\
\hline
\end{tabular}

Early Byzantine Greek (VII-VIII AD)

\begin{tabular}{|c|c|c|c|}
\hline Apocalypse & $\begin{array}{l}\text { Pseudo- } \\
\text { Methodius }\end{array}$ & VII AD & $\begin{array}{l}\text { A.C. Lolos. 1976. Die Apokalypse des } \\
\text { Ps.-Methodios. Meisenheim am Glan: Hain. }\end{array}$ \\
\hline Histories & $\begin{array}{l}\text { Theophylact } \\
\text { Simocatta }\end{array}$ & VII AD & $\begin{array}{l}\text { C. de Boor. 1887. Theophylacti Simocattae } \\
\text { historiae. Leipzig: Teubner. }\end{array}$ \\
\hline $\begin{array}{l}\text { Laudation of St. } \\
\text { Anastasius the Persian }\end{array}$ & George Pisida & VIIAD & $\begin{array}{l}\text { B. Flusin. 1992. Saint Anastase le Perse et } \\
\text { l'histoire de la Palestine au début du viie } \\
\text { siècle, vol. 1. Paris: Centre National de la } \\
\text { Recherche Scientifique. }\end{array}$ \\
\hline $\begin{array}{l}\text { Laudation of St.John } \\
\text { Chrysostomus }\end{array}$ & $\begin{array}{l}\text { John of } \\
\text { Damascus }\end{array}$ & VII AD & $\begin{array}{l}\text { P.B. Kotter. 1988. Die Schriften des Johannes } \\
\text { von Damaskos, vol. 5. Berlin \& New York: De } \\
\text { Gruyter. }\end{array}$ \\
\hline $\begin{array}{l}\text { Laudation of St. } \\
\text { martyr Anastasia }\end{array}$ & $\begin{array}{l}\text { John of } \\
\text { Damascus }\end{array}$ & VII AD & $\begin{array}{l}\text { P.B. Kotter. 1988. Die Schriften des Johannes } \\
\text { von Damaskos, vol. 5. Berlin \& New York: De } \\
\text { Gruyter. }\end{array}$ \\
\hline $\begin{array}{l}\text { Laudation of St. } \\
\text { martyr Barabara }\end{array}$ & $\begin{array}{l}\text { John of } \\
\text { Damascus }\end{array}$ & VIIAD & $\begin{array}{l}\text { P.B. Kotter. 1988. Die Schriften des Johannes } \\
\text { von Damaskos, vol. 5. Berlin \& New York: De } \\
\text { Gruyter. }\end{array}$ \\
\hline $\begin{array}{l}\text { Life ofJohn the } \\
\text { Merciful }\end{array}$ & $\begin{array}{l}\text { Leontius of } \\
\text { Naples }\end{array}$ & VII AD & $\begin{array}{l}\text { A.-J. Festugière \& L. Rydén. 1974. Léontios de } \\
\text { Néapolis, Vie de Syméon le Fou et Vie de Jean } \\
\text { de Chypre. Paris: Geuthner. }\end{array}$ \\
\hline Life of St. Auxibius & & VIIAD & $\begin{array}{l}\text { J. Noret. 1993. Hagiographica Cypria. } \\
\text { Turnhout: Brepols. }\end{array}$ \\
\hline $\begin{array}{l}\text { Life of St. Gregory the } \\
\text { Theologian }\end{array}$ & $\begin{array}{l}\text { Gregory the } \\
\text { Presbyter }\end{array}$ & VII AD & $\begin{array}{l}\text { X. Lequeux. 2001. Gregorii Presbyteri Vita } \\
\text { Sancti Gregorii Theologi. Turnhout: Brepols. }\end{array}$ \\
\hline
\end{tabular}




\begin{tabular}{llll}
\hline $\begin{array}{l}\text { Life of St. Symeon the } \\
\text { Fool }\end{array}$ & $\begin{array}{l}\text { Leontius of } \\
\text { Naples }\end{array}$ & VIIAD & $\begin{array}{l}\text { A.-J. Festugière \& L. Rydén. 1974. Léontios de } \\
\text { Néapolis, Vie de Syméon le Fou et Vie de Jean } \\
\text { de Chypre. Paris: Geuthner. }\end{array}$ \\
$\begin{array}{lll}\text { Life of St. Theodore of } \\
\text { Syceon }\end{array}$ & $\begin{array}{l}\text { George of } \\
\text { Syceon }\end{array}$ & \multirow{2}{*}{ VIIAD } & $\begin{array}{l}\text { A.-J. Festugière. 1970. Vie de Théodore } \\
\text { de Sykeôn, vol. 1. Brussels: Société des } \\
\text { Bollandistes. }\end{array}$ \\
\hline
\end{tabular}

\begin{tabular}{|c|c|c|c|}
\hline $\begin{array}{l}\text { XLV miracles of St. } \\
\text { Artemius }\end{array}$ & & VIIAD & $\begin{array}{l}\text { A. Papadopoulos-Kerameus. 19o9. Varia } \\
\text { graeca sacra. St. Petersburg: Kirschbaum. }\end{array}$ \\
\hline $\begin{array}{l}\text { Miracles of St. } \\
\text { Demetrius }\end{array}$ & $\begin{array}{l}\text { John of } \\
\text { Thessalonica }\end{array}$ & VII AD & $\begin{array}{l}\text { P. Lemerle. 1979. Les plus anciens recueils } \\
\text { des miracles de saint Démétrius et la } \\
\text { pénétration des Slaves dans les Balkans, } \\
\text { vol. 1. Paris: Centre National de la Recherche } \\
\text { Scientifique. }\end{array}$ \\
\hline
\end{tabular}

\begin{tabular}{|c|c|c|c|}
\hline $\begin{array}{l}\text { Narration of the } \\
\text { miracles of Sts. Cyrus } \\
\text { and John }\end{array}$ & Sophronius & VIIAD & $\begin{array}{l}\text { N. Fernández Marcos. 1975. Manuales y } \\
\text { anejos de Emérita 31, 243-40o. Madrid: } \\
\text { Instituto Antonio de Nebrija. }\end{array}$ \\
\hline Paschal Chronicle & & VII AD & $\begin{array}{l}\text { L. Dindorf. } 1832 . \text { Chronicon paschale, vol. } 1 . \\
\text { Bonn: Weber. }\end{array}$ \\
\hline $\begin{array}{l}\text { Passion of the great } \\
\text { martyr Artemius }\end{array}$ & $\begin{array}{l}\text { John of } \\
\text { Damascus }\end{array}$ & VIIAD & $\begin{array}{l}\text { P.B. Kotter. 1988. Die Schriften des Johannes } \\
\text { von Damaskos, vol. 5. Berlin \& New York: De } \\
\text { Gruyter. }\end{array}$ \\
\hline
\end{tabular}

\begin{tabular}{|c|c|c|}
\hline $\begin{array}{l}\text { Two shorter lives of } \\
\text { Theodore of Syceon }\end{array}$ & VII AD & $\begin{array}{l}\text { A.-J. Festugière. 1970. Vie de Théodore } \\
\text { de Sykeôn, vol. 1. Brussels: Société des } \\
\text { Bollandistes. }\end{array}$ \\
\hline
\end{tabular}

\begin{tabular}{|c|c|c|c|}
\hline $\begin{array}{l}\text { Passion of St. } \\
\text { Parasceva }\end{array}$ & John of Euboea & VII/VIII AD & $\begin{array}{l}\text { F. Halkin. 1966. La Passion de Sainte } \\
\text { Parascève par Jean d'Eubée. Heidelberg: } \\
\text { Winter. }\end{array}$ \\
\hline Life of St. Benedictus & Pope Zacharias & VIII AD & $\begin{array}{l}\text { G. Rigotti. 2001. Vita di s. Benedetto nella } \\
\text { versione greca di papa Zaccaria. Alessandria, } \\
\text { Italy: Edizioni dell'Orso. }\end{array}$ \\
\hline
\end{tabular}

\begin{tabular}{|c|c|c|c|}
\hline $\begin{array}{l}\text { Martyrium of Julian } \\
\text { and Basilissa }\end{array}$ & & VIIIAD & $\begin{array}{l}\text { F. Halkin. 1980. La passion ancienne } \\
\text { des saints Julien et Basilisse. Analecta } \\
\text { Bollandiana } 98,243^{-296 .}\end{array}$ \\
\hline Chronography & $\begin{array}{l}\text { Theophanes } \\
\text { Confessor }\end{array}$ & VIII/IXAD & $\begin{array}{l}\text { C. de Boor. } 1883 \text {. Theophanis chronographia, } \\
\text { vol. 1. Leipzig: Teubner. }\end{array}$ \\
\hline $\begin{array}{l}\text { Laudation ofJohn } \\
\text { Chrysostomus }\end{array}$ & Cosmas Vestitor & VIII/IXAD & 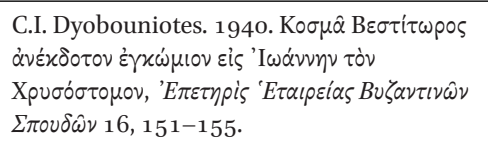 \\
\hline $\begin{array}{l}\text { Laudation of St. } \\
\text { Mocius }\end{array}$ & $\begin{array}{l}\text { Michael } \\
\text { Syncellus }\end{array}$ & VIII/IXAD & $\begin{array}{l}\text { H. Delehaye. 1912. Saints de Thrace et de } \\
\text { Mésie. Analecta Bollandiana 31, 176-187. }\end{array}$ \\
\hline $\begin{array}{l}\text { Laudation of } \\
\text { Theophanes Confessor }\end{array}$ & $\begin{array}{l}\text { Theodorus } \\
\text { Studites }\end{array}$ & VIII/IXAD & $\begin{array}{l}\text { S. Efthymiadis. 1993. Le panégyrique de } \\
\text { S. Théophane le Confesseur par S. Théodore } \\
\text { Stoudite (BHG 1792b). Analecta Bollandiana } \\
111,268-284 .\end{array}$ \\
\hline
\end{tabular}




\begin{tabular}{|c|c|c|c|}
\hline $\begin{array}{l}\text { Life of Gregory the } \\
\text { Decapolite }\end{array}$ & $\begin{array}{l}\text { Ignatius the } \\
\text { Deacon }\end{array}$ & VIII/IXAD & $\begin{array}{l}\text { G. Makris. 1997. Ignatios Diakonos und die } \\
\text { Vita des Hl. Gregorios Dekapolites. Stuttgart: } \\
\text { Teubner. }\end{array}$ \\
\hline Life of Nicephorus & $\begin{array}{l}\text { Ignatius the } \\
\text { Deacon }\end{array}$ & VIII/IXAD & $\begin{array}{l}\text { C. de Boor. 1880. Nicephori archiepiscopi } \\
\text { Constantinopolitani opuscula historica. } \\
\text { Leipzig: Teubner. }\end{array}$ \\
\hline $\begin{array}{l}\text { Life of St. Andrew of } \\
\text { Crete }\end{array}$ & $\begin{array}{l}\text { Nicetas the } \\
\text { Patrician }\end{array}$ & VIII/IXAD & 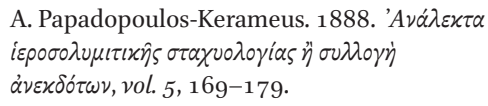 \\
\hline $\begin{array}{l}\text { Life of Stephan the } \\
\text { Younger }\end{array}$ & $\begin{array}{l}\text { Stephan the } \\
\text { Deacon }\end{array}$ & VIII/IXAD & $\begin{array}{l}\text { M.-F. Auzépy. 1997. La Vie d'Étienne le Jeune } \\
\text { par Étienne le Diacre. Aldershot/Brookfield: } \\
\text { Variorum. }\end{array}$ \\
\hline $\begin{array}{l}\text { Life of Tarasius the } \\
\text { Patriarch }\end{array}$ & $\begin{array}{l}\text { Ignatius the } \\
\text { Deacon }\end{array}$ & VIII/IXAD & $\begin{array}{l}\text { S. Efthymiadis. 1998. The Life of the Patriarch } \\
\text { Tarasios by Ignatios the Deacon. Aldershot, } \\
\text { England: Ashgate. }\end{array}$ \\
\hline $\begin{array}{l}\text { Three laudations on } \\
\text { St. Zacharias }\end{array}$ & Cosmas Vestitor & VIII/IXAD & $\begin{array}{l}\text { F. Halkin. } 1987 . \text { Zacharie, père de Jean } \\
\text { Baptiste. Trois panégyriques par Cosmas } \\
\text { Vestitor. Analecta Bollandiana } 105 \text {, } \\
252-263 \text {. }\end{array}$ \\
\hline
\end{tabular}

